SEIZING THE ELEPHANT:

KANSAS CITY AND THE GREAT WESTERN MIGRATION, 1840-1865

A Dissertation

presented to

the Faculty of the Graduate School

at the University of Missouri-Columbia

In Partial Fulfillment

of the Requirements for the Degree

Doctor of Philosophy

By

DARIN TUCK

John H. Wigger

JULY 2018 
(C) Copyright by Darin Tuck 2018

All Rights Reserved 
The undersigned, appointed by the dean of the Graduate School, have examined the dissertation entitled

\section{SEIZING THE ELEPHANT: KANSAS CITY AND THE GREAT WESTERN MIGRATION, 1840-1865}

Presented by Darin Tuck,

a candidate for the degree of doctor of philosophy,

and hereby certify that, in their opinion, it is worthy of acceptance.

Professor John Wigger

Assoc. Professor Catherine Rymph

Assoc. Professor Robert Smale

Assoc. Professor Rebecca Meisenbach

Assoc. Professor Carli Conklin 
To my mother and father, Ronald and Lynn Tuck My inspiration 


\section{ACKNOWLEDGMENTS}

This dissertation was only possible because of the financial and scholarly support of the National Park Service's National Trails Intermountain Region office. Frank Norris in particular served as encourager, editor, and sage throughout it all. I was also welcomed into a community of trail scholars. They shared sources, talked on the phone, and gave me their expert opinions that greatly improved this work. Craig Crease, Mark Brooks, The Oregon-California Trails Association and their journal Overland Journal were gold mines of sources and interpretations. Their love of history and attention to detail are a credit to the history world. Archivists at the Kansas State Historical Society, State Historical Society of Missouri, National Archives in Kansas City, and the National Frontier Trails Museum were always gracious and welcoming.

My dissertation committee of Catherine Rymph, Rebecca Meisenbach, Robert Smale, and Carli Conklin came through for me as this dissertation date neared. I cannot thank them enough for their time and insightful reading of this manuscript. Additionally, the staff of the University of Missouri, especially Patty Eggleston, Nancy Taube, and Lynn Summers, constantly kept me on track and without them graduation would probably not have happened. And finally, John Wigger has been truly taught me how to be a historian. His kindness and encouragement were not only a gift to me, but the profession at large.

The only reason this manuscript exists is because of the love given to me by friends and colleagues. The crew of fellow "Wiggerites," as they became known, like Joshua Rice, Jonathan Root, Cassie Yacovassi, Jenny Wiard, Luke Schlief, Brandon 
Flint, and Hunter Hampton, were my fellow warriors in the process. Far better historians than I, they provided their intellectual rigor and friendship throughout all the years.

The families and friends, too numerous to name, kept me a sane academic and made life possible in the most difficult of times. Hannah McClure and Ethan Anderson, in particular, helped at important times to make sure this project got done. My brothers Cory, Kurtis, and Evan were always there when I needed them.

I would also like to thank the men and women whose words survive and make up the backbone of this book, at least the ones who wrote legibly. For those with sloppy pens or wrote both vertically and horizontally, I'm glad you are dead.

And finally, this work is dedicated to my parents, Ron and Lynn Tuck. Everything good about me is only due to them. 


\section{TABLE OF CONTENTS}

ACKNOWLEDGEMENTS

INTRODUCTION: SEIZING THE ELEPHANT 1

CHAPTER ONE: EXPLORING THE ELEPHANT, 1840-1849 13

CHAPTER TWO: ESTABLISHING THE ELEPHANT, 1850-1854 45

CHAPTER THREE: ENDURING THE ELEPHANT, 1855-1859 74

CHAPTER FOUR: EMBRACING THE ELEPHANT, 1860-1865 118

$\begin{array}{ll}\text { CONCLUSION } & 157\end{array}$

$\begin{array}{ll}\text { WORKS CITED } & 161\end{array}$

$\begin{array}{ll}\text { VITA } & 170\end{array}$ 
Introduction "Seizing the Elephant"

The famed editor of the New York Tribune, Horace Greeley, reportedly once said, "Go west, young man, and grow up with the country." Probably apocryphal, the sentiment was quintessential Greeley by the 1850s. His newspaper had brought him to national prominence and made him one of the most powerful and influential Americans of the antebellum era. A fervent believer in the promises of manifest destiny, Greeley took his own advice on the eve of the American Civil War and left New York for California. He had spent the previous two decades pushing the government to open western land and encouraging the downtrodden to venture west for jobs, success, and opportunity. He stated, "If any young man is about to commence the world, we say to him, publicly and privately, Go to the West; there your capacities are sure to be appreciated, and your energy and industry rewarded."2 He believed in the transcontinental railroad that ran to the Pacific coast and brought the American reader along for the ride as he published a series of essays on his journey. Traveling by rail, steamboat, and wagon, his dispatches were laced with excitement and knowledge of a man who had only read about the American West in the hundreds of books, travel guides, and letters that had been published for the previous three decades. Like many of the hundreds of thousands of pioneers that had come before him, his imagination danced with the possibility of what would certainly come if Americans embraced its manifest destiny.

${ }^{1}$ Greeley's biographer Robert C. Williams wrote of the quote: "Horace Greeley probably did not coin the phrase that made him famous. But he essentially espoused its message from 1837 until the end of his life." Robert C. Williams, Horace Greeley: Champion of American Freedom (New York: New York University Press, 2006), 40.

${ }^{2}$ Williams, 43. 
As he rode, he saw a nation at work. The environment bent to the plow and the axe. The fields filled with workers who were filing into the nature's bounty that simply waited to be conquered. He crossed through the prairies of Missouri through "one of the most beautiful and inviting regions I ever passed over.” He finally arrived at St. Joseph, a small town that did not exist two decades earlier, but now was connected to the Atlantic by a newly opened railroad. Situated on the Missouri River, the city hosted around ten thousand inhabitants, many of whom had the same idea of heading west. He looked at the Missouri River and remarked, "It's muddiness is beyond all description." And in true Greeley-journalistic fashion, he began to do just that. "It's color and consistency are those of thick milk porridge; you could not discern an egg in a glass of it." Venturing out on the trail a few miles, he looked to the horizon and saw the white canvas of a moving wagon train. He wrote, "I have long been looking for the West, and here it is at last."

A popular parable during the mid-nineteenth century concerned a farmer who dreamt of seeing an elephant for the first time. It became his life's desire and brought him close to mania because of it. One day he loaded his wagon full of crops, eggs, and poultry, and headed to the market where he finally gazed upon the largest of the quadrupeds. Unfortunately, his horse had also never seen an elephant and panicked, upturning the cart and ruining the farmer's prized possessions. Thrown from his cart, the farmer dusted off his trousers and remarked, "A fig for the damage, for I have seen the elephant!"4 Though the details of the story changed on every retelling, the moral tended

${ }^{3}$ Horace Greeley, Overland Journey (Ann Arbor: University Microfilms, Inc., 1966), 17-19. Originally published Greeley, An Overland Journey from New York to San Francisco in the Summer of 1859 (New York: C. M. Saxton, Barker \& Co., 1860).

${ }^{4}$ New York Times, March 1, 1861. 
to remain the same. Despite a life now wrecked with hardship and adversity to come, "seeing the elephant," the experience of which he dreamed for so long, was worth it all.

For the thousands of overland travelers that traversed the American West, the phrase of "seeing the elephant" had become so idiomatic that it became a badge of honor or a rallying cry for those headed to California. Some migrants painted the phrase on their wagons. Others wrote home about the elephant that they had seen. Probably an Americanism slightly altered from the English phrase "seeing the lion," it probably shifted as circuses became spectacle in the antebellum period. John Russell Bartlett's 1848 Dictionary of Americanisms described the phrase to mean "to undergo any disappointment of high-raised expectations." It gained and took on additional meaning among the soldiers in the Mexican War in 1846 to 1848 . Bartlett continued, "Men who have volunteered for the Mexican war, expecting to reap lots of glory and enjoyment, but instead have found only sickness, fatigue, privations, and suffering, are currently said to have "seen the elephant." ${ }^{5}$ Other commenters described the phrase as "to see all there is to see," "to see or exhibit something strange or wonderful; especially to see for the first time, or exhibit to a stranger, the sights and scenes of a great city," "having enough," "to gain experience, usually by suffering had knocks," or "to succeed in a most difficult undertaking." Captain J. Goldsborough Bruff kept a running list of "elephants" in his travel journal every time he ran into unfortunate circumstances, "Buffalo-chip fuelSetting supper and Indians running off their animals. Elephant No. 3." Later, "Seeing Elephant No. 4. The Buffalo Hunt. The Buffalo are not quite so green as some folks

${ }^{5}$ Robert W. Johannsen, To the Halls of the Montezumas: The Mexican War in American Imagination (New York: Oxford University Press, Inc., 1985), 87. 
think." And another, "Seeing the Elephant No. 6. Mining. Comrade ill, mule dead, provisions short, diggings run out, varmints \& ingins down — time to put." ${ }^{\circ}$ The popularity of the phrase grew on the trails and into the national consciousness and into the American lexicon. ${ }^{7}$

This work examines the people that wanted to "see the elephant" and the cities that launched them toward it. It does this by focusing on the "head" of the elephant, or the trailhead towns on the Missouri River, particularly Kansas City, by examining both the local changes and the greater migration patterns of the people who moved through them. Around 250,000 to 300,000 Americans decided to venture west between 1840 and 1865 in the great migration that reshaped life on the American continent. ${ }^{8}$ Further, this work is among the first that examines Bleeding Kansas and the Civil War on the KansasMissouri border through the lens of economic activity and migration that were of great concern to the trailhead cities. Taken together, this offers a more complete picture of how each developed chronologically and shaped the American experience west.

Overland Emigration to Oregon, California, Utah, 1840-60

\begin{tabular}{|r|r|r|r|r|}
\hline \multicolumn{1}{|c|}{ Year } & Oregon & \multicolumn{1}{c|}{ California } & \multicolumn{1}{c|}{ Utah } & \multicolumn{1}{c|}{$\begin{array}{l}\text { Yearly } \\
\text { Total }\end{array}$} \\
\hline 1840 & 13 & - & - & 13 \\
\hline 1841 & 24 & 34 & - & 58 \\
\hline 1842 & 125 & - & - & 125 \\
\hline 1843 & 875 & 38 & - & 913 \\
\hline 1844 & 1,475 & 53 & - & 1,528 \\
\hline 1845 & 2,500 & 260 & - & 2,760 \\
\hline
\end{tabular}

${ }^{6}$ J. Rea, "Seeing the Elephant," Western Folklore 28, no. 1 (January 1969), 24.

${ }^{7}$ Rea, 22-25.

8 John D. Unruh, Jr., The Plains Across: The Overland Emigrants and the TransMississippi West, 1840-1860 (Urbana: University of Illinois Press, 1979), xv. 


\begin{tabular}{|r|r|r|r|r|}
\hline 1846 & 1,200 & 1,500 & - & 2,700 \\
\hline 1847 & 4,000 & 450 & 2,200 & 6,650 \\
\hline 1848 & 1,300 & 400 & 2,400 & 4,100 \\
\hline 1849 & 450 & 25,000 & 1,500 & 26,950 \\
\hline 1850 & 6,000 & 44,000 & 2,500 & 52,500 \\
\hline 1851 & 3,600 & 1,100 & 1,500 & 6,200 \\
\hline 1852 & 10,000 & 50,000 & 10,000 & 70,000 \\
\hline 1853 & 7,500 & 20,000 & 8,000 & 35,500 \\
\hline 1854 & 6,000 & 12,000 & 3,167 & 21,167 \\
\hline 1855 & 500 & 1,500 & 4,684 & 6,684 \\
\hline 1856 & 1,000 & 8,000 & 2,400 & 11,400 \\
\hline 1857 & 1,500 & 4,000 & 1,300 & 6,800 \\
\hline 1858 & 1,500 & 6,000 & 150 & 7,650 \\
\hline 1859 & 2,000 & 17,000 & 1,431 & 20,431 \\
\hline 1860 & 1,500 & 9,000 & 1,630 & 12,130 \\
\hline Total & $\mathbf{5 3 , 0 6 2}$ & $\mathbf{2 0 0 , 3 3 5}$ & $\mathbf{4 2 , 8 6 2}$ & $\mathbf{2 9 6 , 2 5 9}$ \\
\hline
\end{tabular}

In Richard White's Pulitzer Prize nominated Railroaded: The Transcontinentals and the Making of Modern America, he brilliantly details the rise of corporate America and the heavy influence of entrepreneurs that used private-public interests, political influence, and market manipulation to create a rail system that crossed the nation. Mistakes and miscalculations appeared to consistently threatened their success, but these business innovators were able to secure transportation systems that transformed the nation after the American Civil War. White wrote that these men that dreamed of modernity and built empires were "not that smart." They succeeded because they "were clever enough at soliciting money and not repaying debts. The shrewdest of them were masters at controlling and manipulating information.” As insightful as White was, however, he missed that all of these innovations were present and functioning in much of the same way before the railroad ever reached Missouri. In short, this work argues that the transcontinental rail system was built on (figuratively and sometimes literally) the 
trail system created during the antebellum and Civil War years. Railroads may have corporatized the program, but the migrants and business leaders in places like Kansas City had already set up a regional economic system that allowed the railroads to thrive in the postwar world. ${ }^{9}$

The historiography of the trails system is extensive, with substantial work being completed often by exceptional amateur sleuths and some of the most meticulous historians one can imagine. Most of the major works are nearing forty years old and have not benefitted from the enormous changes that have impacted the historiography of the West. Furthermore, the majority of works focus on the early period of the trails (18201853). This is partially due to the "pioneering spirit" that simply makes a more entertaining story and has long captured the American imagination both in contemporary and modern lives. Stories of overland wagons and migrants living a frontier life or video games about an Oregon Trail adventure are valuable ways to help understand the past. Two masterful works dominate the subfield. Merrill J. Mattes's The Great Platte River concentrates on the Oregon-California trail that moved from trailheads and along the Platte River by examining more travel diaries and journals than probably any person who has ever lived. John Unruh's magisterial The Plains Across is the most complete synthesis of Oregon, California, and Utah migration, focusing mainly on the daily lives of the migrants and the change to overland travel from 1840 to 1860 . Taken together, these

${ }^{9}$ Richard White, Railroaded: The Transcontinentals and the Making of Modern America (New York: W. W. Norton \& Company, 2011), xxxii. 
works spend less time tracking the changes of trailheads, and do little with disruptions caused by Bleeding Kansas and the American Civil War. ${ }^{10}$

Local histories of the trailhead cities often focus on the early years of the trails. The most extensive investigation into the development of Kansas City was Charles P. Deatherage's multivolume Early History of Greater Kansas City published in 1927. The author's work was both helped and hurt by access to people who actually lived through some of the events and does not use footnotes. Louise Barry's masterful tome The Beginning of the West is used extensively in this manuscript until the year 1855. Barry systematically looked at letters, newspapers, and governmental records to produce a mostly primary source reader. ${ }^{11}$ While the histories of Mattes and Unruh miss the local, Deatherage and Barry focus less on the larger narratives of overland migration. This is an attempt to bridge the gap between both, to update the narrative with more recent shifts in western and Civil War Era historiography, and to include the hundreds of primary sources discovered since these works have be published.

This work adds to the historiography in three substantial ways. First, these historians have focused mainly on the competition of the jumping off towns and the major leaders trying to sway travel and business throughout the early trails period. By focusing on the latter period of overland trail development, this work reorients the

${ }^{10}$ Merrill J. Mattes, The Great Platte Road (Lincoln: Nebraska State Historical Society, 1969).

${ }^{11}$ Charles P. Deatherage, Early History of Greater Kansas City (Kansas City: Interstate Publishing Company, 1927); Louise Barry, The Beginning of the West: Annals of the Kansas Gateway to the American West 1540-1854 (Topeka: Kansas State Historical Society, 1972). Barry had access to sources that do not exist anymore. Wherever possible, the original source was confirmed, but I still attributed it to Barry to recognize her work. 
economic-geographic conception of the macroeconomic system that implicitly or occasionally explicitly views the development on the border as unrestrained free market capitalism. Instead, the governmental role was enormous as it invested heavily in making the trail safer and more expedient for travel. Not only were ideological and political ideas that pushed Americans west, but also the trails themselves were actualized through government money through surveyors, military protections, and governmental contracts for private freight companies and mail systems. Furthermore, the competitive nature of the town promoters of Independence, Westport, Kansas City, Weston, Leavenworth, and Council Bluffs have heavily influenced historians' perceptions of economic activity. ${ }^{12}$ However, what actually developed was an economic monoculture tied to outfitting western travelers that arrived seasonally to buy goods from eastern markets that were brought by steamboat on the Missouri River from St. Louis. Demand greatly outpaced supply as cities with less than a thousand people now had migrants that numbered in the thousands. Since oxen, mules, and cattle needed large grazing ranges, the need for multiple cities became a necessity, a process called "clustering," whereby the competitive towns were all buoyed by the increased commerce. The trailheads developed relatively simultaneously to service the needs of the migrants. This developmental process is what economists call an inelasticity of supply where the towns could not meet the needs of seasonal migration, resulting in the rise of competitors benefitting from direct, indirect, and induced regional economic growth.

${ }^{12}$ A note on names: Since this work moves chronologically, the names of towns and cities that changed names will generally follow a similar timeline. Jackson County organized the town of Kansas in 1850 and chartered the City of Kansas on February 22, 1853. Kanesville became Council Bluffs in 1852 after the majority of Mormons had ventured west. 
Perhaps an analogy would help. Picture an evening at a baseball game, and since we are talking about Kansas City we can use Kauffman Stadium's 2015 World Series champions, the Kansas City Royals. Around the seventh-inning stretch, your hunger sets in and you join the crowd as it goes to the myriad of concession stands (trailheads) that largely sell the same goods no matter where one is in the stadium. The consumer's choice, because almost all else is equal, is the nearest stand that sells the desired hotdog. But since this is the busiest time of the game to get a hotdog (inelasticity of supply), the lines nearest to you may be overflowing. Since the best hitter Salvador Perez is up to bat in the next inning, efficiency is key. So you continue onto the next stand that maybe has run out of hotdogs and their business is temporarily disrupted (like a cholera outbreak, reduced goods, or border violence on the trails). By now, the hunger increases, and you are committed and continue on to the next stand where the line is shorter, and you purchase a hotdog (direct impact). Your wandering has also made you parched so you buy a pint of Boulevard as well (indirect impact). Gleefully returning to your seat with mystery meat wrapped in a bun, you have benefitted from the multiple choices (clustering). The stadium in general has generally profited (induced regional impact) from selling you an overpriced hotdog that is far more expensive than the one in your refrigerator at home (demand outpacing supply). In short, the concessions, while in some ways seen as competitors, serviced their customers and used their profit use to make future purchases easier for the customer (for instance, making the trails safer and more efficient) ${ }^{13}$

${ }^{13}$ Certainly, the Royals would not use the money to invest in better starting pitching. Special thanks to Dylan Moore, a former Royals usher, for helping with this analogy. 
Second, by tracing the development of the trailheads over the majority of their existence, this work traces the growing ease of travel that the migrants experienced throughout the period. Due to heavy government investment, greater knowledge of the trails, and better outfitting towns, migration became safer and more reliable. Indeed, the majority of problems that overlanders faced between 1853 and 1865 were problems that they created themselves and not the dangers of an untamed wilderness. The thousands of emigrants competed over the limited natural resources (like wood and grass) and brought with them epidemic diseases like cholera that proved disastrous for many companies. In short, the environment of the trails had become less deadly than the environs that the migrants created.

Finally, though most histories have focused on trade disruption and provincial competition between 1854 and 1865 , this work contends that the period is better understood as one of dogged resiliency and interdependence of border towns during the turbulent years of Bleeding Kansas and the Civil War. Perhaps surprising to most historians, is the lack of attention paid to sectional strife discussed or even noted in the diaries or memoirs of those who passed through Kansas City between 1850 to the end of the war. Very seldom were migrants attacked or looted on their trip west, and often those were due to extraneous circumstances rather than a concerted effort by pro or antislavery forces. Furthermore, there is little evidence that suggests these changes in migration patterns and trade had to do with Civil War related direct violence outside of some major events (such as the battle of Westport in October 1864). If trade or migration was disrupted due to violence or disease, it tended to come back relatively quickly. So little is known about trade and migration through Kansas City during these years, that the 
National Park Service, which has completed extensive research of nearly all aspects of trail life, commissioned this study due to lack of knowledge about the period and place.

Constructing the world of the trail systems in and around Kansas City, required an extensive source base. I consulted trail diaries and trail journals published or held by the Kansas State Historical Society, The State Historical Society of Missouri, National Frontier Trails Museum, and National Archives. These number in the hundreds, with many more published in various historical journals and newspapers over the past 150 years. I gave primacy to the diaries and journals of these travelers traveling through border towns because they are less biased than actors in the local towns about where they should go. While writers and businesses benefitted by celebrating their town resources, the migrants for the most part operated on the best information they had to make the best decision. This was combined with the diaries, letters, and business ledgers of residents of Missouri and Kansas, particularly in Kansas City, Independence, and St. Joseph. I also used local and national newspapers along with state and national governmental records, which include records from the military, Congress, the Bureau of Indian Affairs, and the United States Census.

Chapter One traces the development of the trail system and investigates its cities and migrants up to 1850 when the gold rush to California brought the exploring overlanders west. Chapter Two traces the establishment of the trails and "jumping off" cities as public and private interests intersected, trail life became less dangerous, and ecological changes affected the wagon trains. Chapter Three explores the impact of border violence on the trail demonstrating how temporary interruptions in trade were endured and overcome through regional economic connections. And finally, Chapter 
Four examines the last stages of the trails, how Kansas City dealt with the deprivations of the Civil War, and the early stages of the railroad.

Abigail Jane Scott, an Oregon Trail emigrant, wrote in her diary of the difficulty of crossing the Blue Mountains of Oregon on September 11, 1852. The terrain was rough and the "dust blow for a time in clouds, hiding the wagons teams and roads entirely from our view." Yet she continued. The rocky roads would have prevented a lesser traveler, but a new life called. She concluded "That anyone who had not begun to 'see the elephant' would have been afraid to have attempted the descent." She, along with the hundreds of thousands like her that made the similar voyage, would alter the course of American history. ${ }^{14}$

${ }^{14}$ Abigail Jane Scott, September 11, 1852. 
Chapter 1 - Exploring the Elephant, 1840-1849

Horace Greeley was not always the voice of westward migration. In fact, he was one of the most prominent voices against it throughout the 1820s and early 1830s as the popularity of the New York Tribune ballooned. Especially as migration increased, Greeley extolled the dangers that constantly affected travelers on the trail. It took too long and trade across Panama was more reasonable, safer, and cost effective. Forts were difficult and expensive to maintain. Taken together, the prospect of mass overland migration was "an act of insanity." Greeley wrote in July 1845 that the only act more stupid than migration was suicide. The overland journey would be a fad that the nation would soon realize was not worth the cost. Though the ensuing years would prove him wrong, at the time his thoughts seemed the height of reason. ${ }^{15}$

But by 1839, Greeley had changed his tune. He hired Thomas Jefferson Farnham to venture west to Oregon to find out as much as possible about the lands and then publish it in his newspaper. "Why? To stake our claim to the Oregon Country, of course! To excite America's imagination! To incite the common man to catch the fever and journey west. Settle there. Spit in the eye of the English.” Farnham arrived in Independence on May 21, 1839. He was going west to settle, while others were going for health and wilderness. It took nine days to outfit and then they set off. The narrative of his journey was often romantic, aimed at encouraging others to follow in his adventures. He talked of trading with Indians and watching them hunt buffalo with great accuracy. He wrote of the great lightning during thunderstorms and marveled at the natural wonder of the Soda Springs in present day Idaho. But not everything went according to plan. The

${ }^{15}$ Unruh, 37-38; 41. 
environment brought rain and snow, wagons broke, and some of his party turned around in frustration. After forty-eight hours without eating, the party gathered and agreed to shoot their "noble dog." After burning off the hair and boiling it, some of the men said it tasted like mutton. Farnham was less impressed, "To me, it tasted like the flesh of a dog. A singed dog. Whether cooked or barking, a dog is still a dog, everywhere.” Arriving in Oregon, it was all worth it. There, he found "American Democracy." His dispatches were turned into articles and later a pamphlet that added to the growing literature on the west. ${ }^{16}$

One traveler going through Kansas in 1849, who arrived at the Big Blue River near Marysville, Kansas, wrote that it was said that it was easy to cross the river "by harnessing the mosquitoes to your teams; they fly above the water and haul you over." They began running into migrants who had turned around and reported they had seen enough of "the Elephant." He continued, "No one seems able to explain that expression—which is the commonest heard along the California Trail." These "quitters" were heading back to Independence and reported, “They've seen too much of the Elephant" or "The Elephant's tracks got too close."17 This chapter traces how the trail system developed and the people who dared to face the elephant head on up to the California gold rush in 1850. Further, it examines the building of the town of Kansas, St.

16 Thomas Jefferson Farnham, An 1839 Wagon Train Journal: Travels in the Great Western Prairies... and in the Oregon Territory (New York: Greeley and McElrath, 1843). In Joyce Badgley Hunsaker, Seeing the Elephant: The Many Voices of the Oregon Trail (Lubbock: Texas Tech University Press, 2003), 48-79.

${ }^{17}$ Archer Butler Hulbert, Forty-Niners, The Chronicle of the California Trail (Boston: Little, Brown \& Company, 1931), 41; B. A. Botkin, ed., A Treasury of American Folklore: Stories, Ballads, and Traditions of the People (New York: Crown Publishers, 1944), 309. For a broad history of the phase dating back to the ancient greeks, see...Peter Tamony "To See the Elephant': It is an old California expression rooted in intrepid man's eternal quest" The Pacific Historian 12, no. 1 (Winter 1968): 23-29. 
Joseph, Westport, and Independence, which would shape migration patterns in their competition to sell to the thousands that would cross in the decade.

During the early years of the republic, it was widely recognized that the future lay west. Indeed, westward expansion was almost part of the nation's DNA before the United States existed. One of the causes of the American Revolution was a widespread desire to push past the Proclamation Line of 1763, which the British had set up in order to limit violence with Native Americans and therefore costing them enormous sums of money to fight back. Americans demurred and moved across the Appalachian Mountains resulting in the expected violence. The purchase of the Louisiana territory from France further highlighted a movement that was already well established and would have continued with or without Thomas Jefferson's bargain. Meriwether Lewis and William Clark set off in 1804 to explore the Pacific Northwest and the lands in between engaging in foreign policy, scientific discovery, trade, and mapmaking that would lay the groundwork for the next century as Americans moved across the frontier. Perhaps even more significant than any of their discoveries was how their findings lit the American imagination with the possibilities that the west had in store. For the young country and its young population, the west remained an almost mythic land of opportunity and equality for the next century. It was vast, untapped, and as Americans would come to believe, it was theirs for the taking.

Native Americans suffered the most from this westward movement. Fueled by white supremacy and the desire for land, the United States government charted a policy that would continuously reduce Native American sovereignty for the next century. This policy went into overdrive after Andrew Jackson's election to the presidency in 1829. 
The Indian Removal Act of 1830 allocated half a million dollars to move tribes in desired lands west of the Mississippi. Some tribes, like the Sauk and Fox fought back but fell to the American military. The southern tribes like the Cherokee, Creek, Chickasaw, and Choctaw chose other measures. The Cherokee sued the state of Georgia for attempting to seize their property and won in the Supreme court. Not to be deterred, the Jackson administration continued their policy, forcing the majority of tribes to the Kansas and Oklahoma territories. The Cherokee that remained in north Georgia were forcibly removed in 1838 along the 1,200-mile trek called the Trail of Tears. The antebellum period proved disastrous for almost all the native tribes that would continue to fight with white Americans that crossed through their newly acquired lands in the territories.

George Bancroft, the famed historian, signaled both optimism and desire in his text with the epigraph of "Westward the star of empire takes its way" in 1834. By the time John L. O'Sullivan declared America's "manifest destiny" in 1845, to conquer the West, it had already become an almost religious purpose and justification for American expansionism. Indeed, westward expansion proved successful because it could mean positive things to almost everyone. Wealthy speculators and railroad companies could buy up the most promising land and resell it for enormous profits to hungry pioneers looking for land and economic opportunity. Businessmen saw new markets to sell their goods and new stores to sell the travelers goods they did and did not need. The urbanization of northeastern cities also presented the problem of overcrowding as hundreds of thousands of immigrants arrived largely from northern Europe. The west not only offered a tension release, but also offered these immigrants land and the ability to create communities like those of their former homelands. Westward expansion also kept 
alive Thomas Jefferson's republican ideas about the virtuous farmer who, because he was independent and self-sufficient, worked for the good of himself and his country to make it prosper. Missionaries and church leaders, spurred on by the Second Great Awakening's Christianity that emphasized a democratic hermeneutic approach to scripture, that gave them ability and postmillennialist desire, took the gospel to distant settlements that were populated by Native Americans. Furthermore, the invention of the penny press, which made newspapers cheaper than ever before, acted like propaganda machines for those seeking their brand of rejuvenation. So while manifest destiny colored both modern and contemporary justifications for westward expansion, a simple ideology alone was not enough. Reasons for the movement west were intersected and proved malleable throughout the antebellum period.

Many Americans began to dream of empire, a nation on par with European nations whose imperialist reach still stood in their way. The weakening Spanish empire throughout Latin America also pushed many in Washington to clarify and extend the nation's borders. John Quincy Adams as Secretary of State not only wanted Florida, but he also wanted to solidify the border with Mexico and Oregon. He got his wish with the Transcontinental Treaty of Washington of 1819. Spain gave up its claims on Florida and set its northern border at the Sabine, Red, and Arkansas rivers up to the $42^{\text {nd }}$ parallel, allowing America to make starker claims to the Oregon Territory. As part of the treaty, America was forced to pay five million dollars accrued by private individuals during the Napoleonic Wars. During the James Monroe administration, the federal government also fought off a Russian push into the Oregon territory and created a joint Anglo-United States alliance that held until 1848. The Monroe Doctrine extended America's sphere of 
influence, at least in American eyes, and promised that the future lay less with Europe and more to the western hemisphere. ${ }^{18}$

Despite America's success, the Era of Good Feelings from 1815 to 1825 was not without its problems. The issue of Missouri loomed large as the population was growing nearer to enough people to gain statehood. And the problem, as with almost every issue of the antebellum era, was tied to slavery. The South in the years since the formation of America became increasingly tied to cotton causing both the rise of property prices and the need for enslaved peoples. Though Missouri never became a land full of slave plantations, it was a valuable political piece in the ever-tenuous balance of slave and free states. With the Missouri Compromise in 1820, Maine was added as a free territory and Missouri became a slave state. In its constitution, Missouri slavery was allowed in perpetuity just in case a future anti-slavery element should arise. Missouri's constitution also forbade "free negroes and mulattoes from coming to and settling in this State."19 Though that would be amended to allow free blacks recognized as citizens, the racial ideology had already begun to coalesce as southerners made up the majority of people entering the state. The admittance of Missouri to the Union signaled that American expansion would continue even though the population and infrastructure lagged behind, except for St. Louis, which had established itself as a gateway city to the West.

It was another event far from Missouri that altered the development of the West in 1821. The "Grito de Dolores" from a Catholic priest named Miguel Hidalgo a decade

18 Daniel Walker Howe, What Hath God Wrought: The Transformation of America, 1815-1848 (Oxford: Oxford University Press, 2007), 108-116.

${ }^{19}$ Howe, 155. 
previous unleashed a revolt against Spanish colonization resulting in a constitutional monarchy and later the Republic of Mexico. Spain had for years failed to protect the trade routes to Santa Fe from Native American raids, so the new government looked for trade partners. For the United States, Mexican independence opened up a lucrative trade with the emerging city of Santa Fe. Silver, pelts, mules, and other Mexican goods that had previously been funneled back to the Spanish crown now were available for the taking. The gamble proved too tempting for a few adventurers that would make the passage to the southwest one of economic significance. Mexico was particularly interested in American cotton and manufactured goods, and its merchants were willing to travel as far as Iowa to set up burgeoning trade connections.

William Becknell of Franklin, Missouri luckily benefitted from Mexican independence and advertised in the Missouri Intelligencer about a trading mission west. In 1820, Franklin, Missouri remained a relatively unimpressive town even though it probably had over 120 cabins. Bucknell's mission was the genesis of many journeys that followed. By September 1821, Becknell set the wheels in motion as he and five companions journeyed from just outside Franklin, to Colorado, south through the mountains to New Mexico, and arrived in Santa Fe where he unloaded the few goods that could be carried by his pack-string of mules. By January, he had returned to Franklin with not only stories of adventure, but also enough silver to invest in another freight journey that would yield even higher profits. Setting off again with three wagons of eastern goods, provided by the steamships growing more popular on the Missouri, 
Becknell led his company on a shorter journey across the Arkansas River through an eighty-mile-long largely waterless Jornada and arrived safely in Santa Fe. ${ }^{20}$

Perhaps few people understood how trade would impact Missouri better than Thomas Hart Benton, one of the new state's new United States senators. A man known to have a short fuse who often responded with fists, he fanned the flames for western development in Washington throughout his career. After Augustus Storrs, for example, made a successful round trip to Santa Fe with Miles Meredith Marmaduke in 1824 with 81 men, 156 horses, and 23 wagons, he informed Benton of the potential profits. Benton then convinced Congress to pay for a road study charted by George Champlin Sibley in 1825-1826. Knowledge of the western trails swiftly spread. The Rocky Mountain Fur Company, formed by General William Henry Ashley of Missouri, was established at the mouth of the Kaw River in 1822. Alphonso Wetmore, who lost his right arm to cannon shrapnel in 1812 , became a paymaster for the army who on the side wrote essays and a history about the Santa Fe Trail. Along with Nathaniel Patten (in the Missouri Intelligencer and Boonslick Advertiser) and other travel writers, the nation had plenty of stories to fill its imagination of Missouri and what lay beyond.

Trade was also encouraged by the dramatic support provided by the United States government, particularly by the American military. Fort Leavenworth was established in May 1827 by Colonel Henry Leavenworth and a portion of the Third Infantry. Its position, just west of Missouri, was thought to help protect both the traffic along the Platte River and the Santa Fe Trail, and to act as a protective barrier to the newly formed

${ }^{20}$ Marc Simmons, The Old Trail to Santa Fe: Collected Essays (Albuquerque: University of New Mexico Press, 1996), 6-9. 
town of Independence. Violence with Native Americans soon followed as three men were allegedly killed by the Comanche and Pawnees in 1828 while the Osages and Kansas Indians had bothered other caravans. The movement of more soldiers and traders to the fort signaled more investment by the federal government, Indian commissioners, and the military. On June 15, 1832, the federal government authorized a body of mounted rangers to help patrol much of the Santa Fe Trail in the United States Territory. ${ }^{21}$ More than a decade later, in August of 1843, Fort Leavenworth received orders to help escort a caravan of 175 wagons owned mostly by Mexican businessmen. After reaching the Arkansas River, they were met by a Mexican escort. ${ }^{22}$ The increased army presence on the trails helped secure both American and Mexican goods, though it did not prove to be completely effective.

Historian Marc Simmons has observed that the 1820s were a period of discovery and experimentation, while the 1830s were one of consolidation. ${ }^{23}$ The beaver fur trade in Colorado and other Rocky Mountain areas contributed to more topographical knowledge and routes west. In 1834, a company led by A. Kerr demonstrated the viability of the Santa Fe Trail. Stopping in Columbia, Missouri, it claimed over $\$ 200,000$ in specie on their journey back east. ${ }^{24}$ Four years later, Josiah Gregg returned from Santa Fe with 23

${ }^{21}$ Henry Putney Beers, "Military Protection of the Santa Fe Trail to 1843," New Mexico Historical Review 12, no. 2 (April 1937).

${ }^{22}$ Beers, 130-131.

${ }^{23}$ Simmons, 11.

${ }^{24}$ Missouri Intelligencer, October 18, 1934. 
men in only 28 days and carried with him $\$ 150,000$ in specie. ${ }^{25}$ Each success signaled more investment with bigger caravans and more goods making the trip west.

Perhaps nowhere was this growth more apparent than in the town of Independence. The town incorporated on July 20, 1829. Townspeople already had multiple taverns by 1834 , and erected the Merchants Hotel in the 1840 s. ${ }^{26}$ Charles Latrobe, who traveled with Washington Irving, gave a glowing report after he arrived in 1832: "The town of Independence was full of promise, like most of the innumerable towns springing up in the midst of the forests in the West, many of which, though dignified by high-sounding epithets, consist of nothing but a ragged congeries of five or six rough log huts, two or three clapboard houses, two or three so-called hotels, alias grogshops; a few stores, a bank, printing office, and barn-looking church. It [Independence] lacked at the time...the three last edifices, but was nevertheless a thriving and aspiring place, in its way." Irving's nephew a year later reported twenty to thirty houses and a courtroom. By 1834, John Townsend, a Quaker ornithologist, updated the figure to fifty houses, six or eight stores, and two taverns. ${ }^{27}$

Historian William Patrick O’Brien's valuable analysis of Independence trade in the 1840s demonstrates how trade overcame regional, ethnic, and language barriers in the pursuit of the almighty dollar. Rather than the popular notion of white settlers predominating the expanse, the city was extraordinarily multicultural as trade with

${ }^{25}$ Deatherage, 323 . This is nearly $\$ 5$ million and $\$ 3.7$ million dollars respectively when adjusted for inflation according to www.westegg.com.

${ }^{26}$ Deatherage, 240.

${ }^{27}$ Richard L. Anderson, "Jackson County in Early Mormon Descriptions," Missouri Historical Review 65, no.3 (April 1971): 281. 
multiple Native American tribes, European immigrants, Americans north and south, and Mexican traders could be seen on its streets. Merchants occasionally advertised their ability to speak local native languages along with fluency in Spanish. ${ }^{28}$ Some of the most successful traders, like David Waldo, applied for Mexican citizenship.

Central to the growth of Independence was a religious community that was moving west in the 1830s for other reasons. The infant Mormon Church moved its operations from New York State to Kirtland, Ohio to escape religious persecution. In Kirtland their ranks grew and they even began establishing missions to the Native Americans in Missouri and eventually established a site for New Zion in Independence. William Wines Phelps, a recent convert to Mormonism, wrote about his first visit to Independence, Missouri in a letter on July 23, 1831:

The inhabitants are emigrants from Tennessee, Kentucky, Virginia, and the Carolinas, etc., with customs, manners, modes of living and a climate entirely different from the northerners, and they hate yankees worse than snakes, because they have cheated them or speculated on their credulity, with so many Connecticut wooden clocks, and New England notions. The people are proverbially idle or lazy, and mostly ignorant; reckoning nobody equal to themselves in many respects, and as it is a slave holding state, Japheth will make Canaan serve him, while he dwells in the tents of Shem. ${ }^{29}$

As trouble grew for the Ohio Mormons throughout the 1830s, with persecution, prosecution, and perpetual money issues always around, they shifted most of their operation to Independence where they were met with even more of the same. Despite harassment by both legal and illegal means, the Mormon Church grew, claiming ten thousand adherents in Missouri by 1838. When the Mormon War broke out that same

${ }^{28}$ William Patrick O'Brien, Merchants of Independence: International Trade on the Santa Fe Trail 1827-1860 (Kirksville, MO: Truman State University Press, 2014), 10.

${ }^{29}$ Anderson, "Jackson County in Early Mormon Descriptions," 276. 
year, the Governor of Missouri, Lilburn Boggs, called out state troops who were to treat the Mormons as "enemies" that needed to be "exterminated." Prophet and leader Joseph Smith would say later in 1842 of the troubles, "But as we could not associate with our neighbors (who were many of them of the basest of men and had fled from the face of civilized society, to the frontier country to escape the hand of justice) in their midnight revels, their sabbath breaking, horseracing, and gambling, they commenced at first [to] ridicule, then to persecute." 30 And after the murder of Smith in 1844, the majority of the Mormon Church fled to Utah in intervening years, charting a path away from Independence into Iowa and across Nebraska.

The great Mormon migration of 1846 to 1847 blazed the path that many of their gentile counterparts would take over the following two decades. Under the guidance of the prophet Brigham Young, around three thousand Mormons began their journey west. With an extraordinary amount of coordination, they set up waypoints for future migrants at places near Omaha, Nebraska, where they set up their Winter Quarters. Before that however, they had established settlements like Garden Grove and Mt. Pisgah. Following the Platte River Road, they blazed the trail making improvements along the way that would benefit migrants to Oregon and especially California during the gold rush. Over the next two decades, seventy thousand Mormons would follow the trail, mostly starting from Kanesville, Iowa (Council Bluffs). ${ }^{31}$

${ }^{30}$ Anderson, "Jackson County in Early Mormon Descriptions," 281.

31 John G. Turner, Brigham Young: Pioneer Prophet (Cambridge: Belknap Press of Harvard University, 2012). 
In 1836, the United States finalized a series of land purchases with Native American tribes such as the Potawatomi, Sac, Fox, and other smaller tribes in the Platte Purchase that gave more access to Westport landing just fifteen miles to the west. Squatters and other entrepreneurs had been encroaching on the land for years, most notably Joseph Robidoux of the American Fur Company. This probably violated both the Missouri Compromise (because it extended slave territory farther north) and also possibly the Indian Removal Act of 1830 (which had only recently moved many native populations to areas which they then gave up). However, this made Westport one of the most dynamic markets for goods moving both east and west. The caravan trade especially boomed as wagon makers along with harnesses, saddles, and tents were being produced and sold in the area. The nearby natives, many whom had been moved across the Missouri River, now receiving government allotments, only expanded the trade by continuing business with a growing population setting up a burgeoning village. Westport, which was founded in 1831 by the Reverend Isaac McCoy, a Baptist missionary, gained a tract of land on the deserted village of the Sauk Indians. His son John opened up a store the following year. The town of Westport built a post office nearby in 1832 and was greatly improved by the building of a four mile long state road that connected the village with a landing on the Missouri River. Independence still had the majority of trade running through it, but with the Platte Purchase, Westport would become a keen competitor until the end of the trail era.

Francis Parkman, when he was setting off west, used Westport to organize and prep for his trip in 1846. He described the scene in his usual colorful way: "Westport was full of Indians, whose little shaggy ponies were tied by the dozen along the houses and 
fences. Sacs and Foxes, with shaved heads and painted faces; Shawnees and Delawares fluttering in calico frocks and turbans; Wyandottes dressed like white men, and a few wretched Kanzas wrapped in old blankets were strolling about the streets or lounging in and out of the shops and houses." Later adding, "whiskey, by the way circulates more freely in Westport than is altogether safe in a place where every man carries a loaded pistol in his pocket." ${ }^{32}$ Independence had assured the continuance of its trade by improving the landing at Blue Mills and Wayne City where people could disembark and, in the latter case, use a "rail road" pulled by mules to get into the town. But, the Missouri River is a fickle beast, and this did not prove to be a long-term solution. By the 1840s, Mary Barile contends Westport had overtaken Independence, though the latter would still command an important presence into the 1850 s. $^{33}$

By the 1840s, there was more than Santa Fe to be desired out west. California provided a connection to the Pacific and therefore another world. The weak Mexican state could never adequately provide for its northern areas that were under constant threat from the Native Americans. This did not seem to bother many Americans who desired opportunity. When the United States experienced another panic in 1839, hundreds of Americans pushed through the Rocky Mountains on their way to a land few Americans knew. Cheap land, if they paid for it at all, was there for the taking. Large caravans could be seen traveling through southern Wyoming and north of the Great Salt Lake to the Great Basin of California. The dangerous trek was made even more unsafe with the

32 Deatherage, 260.

${ }^{33}$ Mary Collins Barile, The Santa Fe Trail in Missouri (Columbia: University of Missouri Press, 2010), 121. 
unpredictable nature of the Sierra Nevada. The quest for opportunity and money drove most of the pioneers across the trail. Moreover, John Unruh has demonstrated that it was helped by a tremendous uncoordinated public opinion campaign throughout the decade through newspaper, books, and travel guides. ${ }^{34}$ The press served as a "meritorious public servant" that created a mythic West full of opportunity and heroes. ${ }^{35}$

In July 1836, traders from the American Fur Company demonstrated that a caravan of wagons could make it through the South Pass of Wyoming where they could turn northwest in search of the Oregon territory. The Hudson Bay Company and other trade organizations had been there for years, but missionaries and settlers were on their way. The most famous, Marcus and Narcissa Whitman, preached the implicit doctrine of manifest destiny as much as they did the doctrine of Christ. In 1843, he offered his expertise to those that were seeking economic benefits as well as escape from malaria in the Mississippi Valley. In that year over a thousand made the trip. By 1844, there were around 5,000 Americans in Oregon and many were willing to settle there on a permanent basis in the Willamette Valley. The British Hudson's Bay Company had long been there as traders and trappers and benefitted from relatively good relations with the Natives. The newly-arrived Americans, however, were there to stay and were willing to incite violence to remain there. ${ }^{36}$

Few presidents had a more ambitious expansionist policy than James K. Polk who cast his eyes on the west. He was willing, politically and militarily, to make sure the west
${ }^{34}$ Unruh, 28-61.
${ }^{35}$ Unruh, 89.
${ }^{36}$ Howe, 712-14. 
was settled by white Americans. He was not only after a large swath of the Oregon territory, but also California, Texas, and New Mexico. As historian Daniel Walker Howe has noted, "Power politics, diplomacy, and war proved as much a part of America's 'manifest destiny' as covered wagons." 37 Democrats like Polk had seen the effectiveness of an aggressive foreign policy with Texas and the push toward war with Great Britain over the disputed territory. His campaign promise of "Fifty-four Forty or Fight" found support from many in Missouri. If Americans were willing to travel to Oregon, they would have to travel through Missouri, and cities like Independence and Westport were more than happy to outfit them. ${ }^{38}$

While Polk was flashing his teeth in Oregon, a war had already broken out in Mexico. This called for a massive militarization, including the protection of commerce on the Santa Fe Trail. Under the leadership of Brigadier General Stephen Watts Kearny, the Army of the West left Fort Leavenworth with 648 regular troops, 1,000 Missouri volunteers and a massive wagon train with 1,556 wagons, 459 horses, 3,658 mules, and 14,904 oxen. A thousand more Missouri volunteers would follow along with 500 men from the Mormon Battalion. Kearny's massive force was formidable and a welcome site among the businesspeople who knew that American military control meant big money. ${ }^{39}$ Though the majority of Mexicans saw the American army as a foreign invader, Kearny and his trips were able to enter Santa Fe without firing a shot. There he appointed a civil

${ }^{37}$ Howe, 707.

${ }^{38}$ Charles Sellers, James K. Polk: Continentalist, 1843-1846 (Princeton: Princeton University Press, 2016), 219.

${ }^{39}$ Howe, 758. 
government with American interests with an almost immediate financial return. St. Louis reported over one million dollars' worth of merchandise in the first couple months, more than triple any previous year's total. ${ }^{40}$ The Mexican War, as it turned out, was a relatively short war that resulted in the American flag being raised in Mexico City. ${ }^{41}$ The ensuing Treaty of Guadalupe Hidalgo ceded an enormous amount of land from Mexico to the United States, The status of those lands - with regard to slavery - further aggravated the slavery debate in America. ${ }^{42}$

The timing of the signing of the Guadalupe Hidalgo treaty could not have been more fortuitous in terms of westward expansion. Just nine days before their signatures, on January 24, 1848, an employee of Johann Sutter discovered gold on Sutter's Ranch east of Sacramento, California. By spring, the secret was no more as men poured into the area from San Francisco and elsewhere along the Pacific coast. Word traveled down the Pacific coast to Chile and Peru and as far away as Australia and China. Thousands of "Forty-Niners" were on their way.

One emigrant described how the wagon trains were painted with mottos like "Wild Yankee," "Rough and Ready," "Live Hoosier," "Never Say Die," "Patience and Perseverance," and "Have You Seen the Elephant" while others had drawings of eagles,

${ }^{40}$ David Dary, The Santa Fe Trail: Its History, Legends, and Lore (Lawrence: University Press of Kansas, 2000), 194.

${ }^{41}$ Ethan Anderson, "War Flags into Peace Flags: The Return of Captured Mexican Battle Flags During the Truman Administration" master's thesis (Kansas State University, 2010).

${ }^{42}$ The phrase "seeing the elephant," historian James M. McCaffrey concluded, "first gained currency" during the Mexican War. James M. McCaffry, The Army in Transformation, 1790-1860 (Westport, CT: Greenwood Press, 2006), 141. 
elephants, giraffes, lions, or oxen, "done in charcoal or black paint with an artistic skill that is bold if not accurate. ${ }^{43}$ Many men returned from the Mexican War with few economic prospects and were eager for adventure. Author George Stewart called 1849 "The Year of Madness" or "The Year of the Greenhorn" as "young men left wives and little children, convinced that they were acting in the best interests of the family. Doctors and lawyers, abandoned good practices. Hundreds of famers mortgaged their land." ${ }^{44}$ The chaos unleashed by the Gold Rush was aided by all the advancement of the previous decade of trail knowledge and business growth on the Missouri River. For those who had the money, there were experienced travelers who had previously made the journey and the number of these experienced travelers grew each year. One could join Captain Benoni Hudspeth, guide J. J. Myers, and pilot Milton McGee who were part of Chiles's horsemen. Edwin Bryant, William "Colonel” Russell made the trip in 1846 whereas Young Billy Graves (who was not really that young) had previously been with the infamous Donner Party. John Bingham, born on July 15, 1828, set out for gold country on the through Santa Fe Trail where he initially found some success in 1849 in California. He wrote to his friend Dr. Glen O. Hardeman, who would later follow, detailing not only travel times and distances between stops on the trip but also where an Indian attack might occur. He scrawled his name at multiple sites for his friend to find and told him he could find plums and grapes at Cold Springs (Oklahoma) and cherries on

${ }^{43}$ May 16, 1849. In J. S. Holliday, The World Rushed In: The California Gold Rush Experience (New York: Simon and Schuster, 1981), 118.

${ }^{44}$ George Stewart, The California Trail: An Epic with Many Heroes (New York: McGraw-Hill, 1962), 217. 
small bushes at Rabbit Ears (northeastern New Mexico). ${ }^{45}$ In 1849, Joseph E. Ware published The Emigrants Guide to California, a small twenty-five cent booklet that reportedly could be sold for an elevated price of ten or fifteen dollars. ${ }^{46}$ There, emigrants could find helpful routes and general advice. Also, a suggested shopping list:

\begin{tabular}{|l|r|l|r|}
\hline Three rifles at \$20 & $\$ 60.00$ & Dried fruit, 50 pounds & 3.00 \\
\hline Three pairs pistols at $\$ 15$ & 45.00 & Salt and pepper, 50 pounds & 3.00 \\
\hline $\begin{array}{l}\text { Five barrels of flour }(1,080 \\
\text { pounds })\end{array}$ & 20.00 & Lead, 30 pounds & 1.20 \\
\hline Bacon, 600 pounds & 30.00 & Tent, 30 pounds & 5.00 \\
\hline Coffee, 100 pounds & 8.00 & Bedding, 45 pounds & 22.50 \\
\hline Saleratus, 10 pounds & 1.00 & Cooking utensils, 30 pounds & 4.00 \\
\hline Lard, 50 pounds & 2.50 & Matches & 1.00 \\
\hline Tea, 5 pounds & 2.75 & Candles, soap, 50 pounds & 5.30 \\
\hline Sugar, 150 pounds & 7.00 & Personal baggage, 150 pounds & - \\
\hline Rice, 75 pounds & 3.75 & TOTAL: 2,505 pounds & $\$ 225.00$ \\
\hline
\end{tabular}

Whereas the average person still made around a dollar a day, the expense forced many to sell all that they owned or to borrow money for the trip. ${ }^{47}$

The 1840s also saw more and more businesses trying to cash in on travelers heading west. Edwin Bryant, for example, arrived in Independence on May 1, 1846. There he purchased three yokes of oxen and paid $\$ 21.67$ per yoke, which he considered cheap. He was even able to hire a man as driver and cook that had experience as a trapper

${ }^{45}$ July 12, 1849. John A. Bingham, "Camp Sites on the Santa Fe Trail in 1848." Edited by Nicholas P. Hardeman. In Arizona and the West: A Quarterly Journal of History 6, no.4 (1964), 313-319.

${ }^{46}$ Todd Webb, The Gold Rush Trail and the Road to Oregon (Garden City, NY: Doubleday, 1963), 40.

${ }^{47}$ Hunsaker, 11. 
in the Rocky Mountains. ${ }^{48}$ Susan Magoffin arrived in Independence on June 9, 1846 and stayed in Mr. Noland's Hotel. She spent the next day doing "considerable business" before setting off on the prairie adventure. ${ }^{49}$ Turner \& Allen, based in Independence, organized a passenger line, provided transportation, rations, and space for a hundred pounds of luggage for two hundred dollars to leave sometime in 1849 from Independence. By the time they had reached Fort Kearny, eleven people of the around 100 had died of cholera. ${ }^{50}$ Niles Searls decided to make the trip to California in April 1849 along with his friend from law school Charles W. Mulford. In Independence, they realized their lack of knowledge in procuring all that was needed for a trip and decided to opt for "comfort and pleasure" and they too turned to a "passenger line." They joined about 120 other passengers, and set off on May $9^{\text {th }}$, but were slowed because of additional baggage carts for the rest of the company. On their trip they met adventure, with Mulford accidentally shooting Searls' horse while they hunted buffalo on the Platte River. About a quarter of their fellow passengers would die on the journey.

Bernard J. Reid recounted his stay in Independence in 1849, when an attack of cholera killed three members of his train party, including "Black" Harris who was an invaluable guide, having made trips to Oregon a number of times previous. Reid had already wasted money in St. Louis learning how to cast gold, which he did poorly. As 1848), 2.

${ }^{48}$ Edwin Bryant, What I Saw in California (New York: D. Appleton \& Company,

${ }^{49}$ Susan Shelby Magoffin, Down the Santa Fe Trail and into Mexico, ed. Stella M. Drumm (Lincoln: University of Nebraska Press, 1926).

${ }^{50}$ Saint Louis Daily Union. February 7, 1849. This train would leave on May 13 and another on June 18. Missouri Republican, St. Louis March 9, 21; April 29, 1849. Barry, 861-2. 
they set off, the mules of the train quickly showed they were not up to the task, the passenger line of Turner \& Co. having bought untested and young mules. "No pen can adequately describe our start," Reid reported, "Half-a-dozen circuses combined in one would have been tame in comparison." 51

On May 5, 1850, John Howlett reported that Independence was a "very pretty town" with an estimated 3,000 people. With so many setting off west, he reported that hay was scarce, oats were nonexistent, and foodstuffs both for person and beast were selling at inflated prices. He reported he got a tooth pulled and negotiated the fee down from $\$ 2$ to $\$ 1$. Cholera had also hit some of his fellow passengers. One, named Mr. C., was "troubled with the diseas called laiseness." 52 By the time he arrived at Fort Kearny on June $8^{\text {th }}$, he was told that nearly 9,000 had already passed through that year. Indeed, the stores at Independence and Westport were exceedingly good at getting emigrants to buy goods that overloaded their wagons. The "extra axletrees and wheels, sheet-iron stoves, anvils, chains, personal clothing, boxes of medicines, shovels, pickaxes, and goldwashing machines; and quantities of foodstuffs — barrels of flour, sacks of sugar, salt cornmeal, beans, coffee, salt pork, and saleratus [baking soda]" not only proved too much weight to be pulled by the mule teams, but caused axles to break and wheels to get stuck anytime that it rained. These materials, and sometimes entire wagons, were left behind, to

${ }^{51}$ Bernard J. Reid, Overland to California with the Pioneer Line: The Gold Rush Diary of Bernard J. Reid (Stanford University Press: Stanford, 1983), 32.

52 John Howlett, Letter, May 5, 1850. 
be scavenged by the people of St. Joseph and Independence that had sold them the goods just weeks before. ${ }^{53}$

In historian Charles P. Deatherage's massive Early History of Greater Kansas City published in 1928, he reveled in the almost supernatural potential for Kansas City to become the "prophetic city at the mouth of the Kaw River." He wrote that it was "plainly evident fact to every thinking man" that greater Kansas City was poised perfectly on the Missouri River and was "border line of the white civilization." In 1845, James H. McGee built on the bluff between Grand Avenue and Walnut Street the first brick house in Kansas City. ${ }^{54}$

Farther west, land was claimed by the Native Americans and thus thwarted the expansion of "civilization" during the 1850s. On January 8, 1849, a speculator named Colonel William Gilpin reported: "Independence now, for twenty years, the emporium of the commerce of the Prairie, possesses indisputable and peculiar advantages over all other places, as the point of rendezvous and final embarkation for emigrants and travelers going to the Pacific." The town had quality land grazing, great land routes, and abundant supplies." He continued at length:

The habitual annual departure and arrival of emigrants, has created a body of skillful mechanics, and all kinds of complete manufacturing establishments in every department of the trades, combined with stores, filled with supplies for all wants and tastes. Here are manufactured (of all sizes) the peculiar wagons, strongly ironed - adapted to resist the dry climate of the high altitudes; harness, saddles, and pack-saddles, for mountain use, tin ware, riveted, to resist fire and accidents in short, flour mills, rope mills, wagon manufactories, tinners, leather manufactories, saddle and harness makers, hatters, farsiers, clothing establishments, assorted goods for the Indian trade (such as vermillion, red cloth, Mackinaw blankets,) gunsmiths are all here established on a permanent and ample

${ }^{53}$ William Swain, 1849. Holliday, 111.

${ }^{54}$ Deatherage, 365. 
scale, and furnish articles of a substantial and durable character to carry the traveler safely beyond the wilderness without the necessity of repair or renewal. ${ }^{55}$

Although Deatherage and Gilpin probably go too far in their verbiage, it's clear that these “jumping off” towns played a major role in America's western migration.

But Westport, Independence, and the town of Kansas were not alone in attracting migrants looking to head west. By 1849, St. Joseph started attracting more and more migrants as a place for jumping off. St. Joseph had the advantage of being on the river while shaving off around eighty miles of overland trail off the tip. Furthermore, it was connected to a reputed faster and firmer overland route through Marysville, Missouri, which attracted those coming from central Missouri that lacked access to steamboats. ${ }^{56}$ St. Joseph had two ferries by 1849 , and by 1852 there were four steam ferries across the Missouri River. A correspondent at St. Joseph estimated over 3,000 people had been through the city and suggested that it was higher than at Independence by late April 1849. ${ }^{57}$ By May, that number had increased when the editor of the Gazette in St. Joseph estimated that eighteen thousand people would travel through the town by the end of the season and another eight thousand would jump off at Independence.

Robert Binns Ellis, a doctor from Richmond, Missouri, was one of an estimated 55,000 that traveled to California in 1850. A recent widower, Ellis began his trip by wagon train in St. Louis to St. Joseph, noting in his diary simply, "nothing remarkable." Though the trip through Missouri echoed other travelers as being increasingly routine, his

${ }^{55}$ Sunday Morning Visitor (Warsaw, Missouri), February 3, 1849.

${ }^{56}$ William E. Lass, "Missouri River Steamboating: The Supplier of the OregonCalifornia Trail," Overland Journal 30, no. 2 (Summer 2012), 54.

${ }^{57}$ April 25, 1849. Barry, 829. 
arrival to St. Joseph on April 20 proved worth explanation. After securing a bed at the City Hotel, he noted that the town had been overrun with gold seekers: "Inhabitants have lost their Identity and can only be distinguished by their own 'Shiboleth,' (exhortion). St. Joseph is a pretty and rather well built town and I doubt not contains many most worthy men, but they were lost, during my stay, in the crowd; at all events, I could not see them. As to women! I heard of none, except Mrs. Armour, an old patient from St. Louis. ${ }^{58}$ Historians of trail migrations have been concerned with the power shifts of the jumping off towns. Charles Deatherage for instance places the demise of economic activity Independence and Westport around the Mexican War. ${ }^{59}$ However, this in many ways overshadows the enormous regional economic impact on these cities. In reality, none of these growing towns could service the needs of the thousands that were coming. Over one hundred thousand migrants would make the voyage west by 1850 , crossing through towns that had populations less than three thousand east of the Missouri River. During peak travel periods, there simply was not enough food grown locally to satisfy the hunger of the emigrants. In 1849, St. Joseph had a population around 1,500, yet had around 10-15,000 migrants at one time in and around the city before the opening of the migration season. Furthermore, the immense needs of grass physically limited the tens of thousands of cattle that needed to feed. This led to the creation of camps outside of the

${ }^{58}$ Robert Binns Ellis, "Scenes and Thoughts by the Way, Trip to Northern California, 1850," Overland Journal 16, no. 2 (Summer 1998): 16-17.

${ }^{59}$ Deatherage, 369-370. William Patrick O'Brien wrote, “Independence lost its status as a premier American western outfitting and freighting center because of local, regional, and ultimately national social conflict, as well as shifts in commercial patterns and centralization of new technologies such as rail transportation. Mormon conflict, Indian persecution, the Mexican War, and Kansas-Missouri border violence created an environment of both uncertainty and instability." O'Brien, 5. 
towns. Though internal and business improvements seemed to grow almost every year, the seasonal nature of travel presented businesses with enormous springs and summers of growth and autumns and winters of fallow. The enormous amount of cargo that moved on the trails started a building craze of new warehouses and outfitting houses that were jockeying for the choicest plots. These towns were also limited by the amount of eastern goods that could even reach them. The Missouri River became increasingly clogged with steamboats carrying much of the same goods that could be sold at any of the towns. Migrants arriving in the flooded Independence, simply went on to the town of Kansas, Westport, or farther up the river to St. Joseph or even Council Bluffs.

Though Independence was a major jumping off point for the gold rush in 1849, its popularity in many respects would contribute to its declining influence. Independence had become so overrun with buyers that there was not enough supply to meet their needs. Furthermore, as camps were set up outside of town, the grass needed to feed the thousands of livestock quickly became more and more scarce, especially for those who came later in the spring season. Many were forced up the trail to St. Joseph and Council Bluffs in search of goods and grass. One letter from St. Joseph in 1849: "From what I have been able to ascertain, there appears to be a greater number of emigrants rendezvousing here than at Independence. At the commencement of the season this was not anticipated by the good people of the latter place, or expected by the businessmen or citizens of St. Joseph. The arrangements of the merchants to meet any demand that might be presented are ample in the extreme and afford facilities for procuring anything for an outfit. The roads in every direction are lined with wagons of migrating parties from the lower counties of Missouri and from Iowa, Wisconsin, Illinois and Michigan.” John 
Goldsborough Bruff skipped right past Independence. The crossing at St. Joseph had become so crowded that fistfights had broken out and he estimated that it would take around thirty hours of waiting in line with his wagons before a ferry would be free. Instead, he and his company continued north to Fort Kearny (Nebraska City) before they crossed the Missouri. ${ }^{60}$

The explosion of emigration to the west coast during 1850 was often accomplished by novices armed with guidebooks and little experience. James and David Lee set off for California as part of the gold rush and jumped from the growing town of St. Joseph. ${ }^{61}$ After arriving in California, he wrote back home with a detailed list of everything a potential emigrant should bring. He emphasized the need to travel light and encouraged them to buy flour, bacon, and other foodstuffs after arriving at the Missouri River though it got increasingly expensive. Little clothing was needed, and he advised “come light as possible to have plenty to eat Don't for get that." They were able to join with the "Mutual Protection Company of California Emigrants" a wagon train that followed the St. Joseph Road through what would become the northern part of Kansas. With his water vessels filled on the Sublette Cutoff in Wyoming in June, Thomas Christy set off to "see if is as large an Elephant as it is represented." 62

${ }^{60}$ Webb, 47-49. Bruff's decision was even smarter because he actually outfitted mostly in Pittsburgh, Pennsylvania so he did not have to compete for wagons and other equipment out west.

${ }^{61}$ David W. Jackson, "Kansas Trails, Tall Grass, and Trials as experienced in the California Gold Rush. Letters and Diary of James and David Lee Campbell," Overland Journal 23, no. 3 (Fall 2005).

${ }^{62}$ Thomas Cristy, June 17, 1850. 
Death would come to many who dared to cross the continent. The trail journal of Lucena Parsons is particularly illuminating. From a period of June 19 to July 18, 1850, she kept track of all the graves that she saw. She saw at least 146 graves, with at least four of them being recognizably children's graves. She remarked on June 29 that "it seems very melancholy to pass so many new graves." At one gravesite she noted that nineteen graves were filled with mostly young Missouri men between the ages of twenty to thirty. Her own party did not fare much better. Two men and three women died along with eight other adults of unknown gender. Additionally, nine children died including one three-year-old boy who fell from the wagon and was run over across his stomach and died an hour later. On July 18, she noted twelve graves: "I see some painful sights where the wolves have taken up the dead \& torn their garments in pieces \& in some instances the skulls \&jaw bones are strewed over the ground."

An outbreak of cholera claimed many on the trail, but inexperience was just as costly. John Wood of Missouri wrote that hundreds of companies had arrived in the state to "meet with difficulties and expenses which they never anticipated; consequently, many start only half prepared and hundreds return home almost sick of life." He estimated a crowd of ten thousand that set off without direction in parties already teeming with disruptive influences. He wrote that "many poor souls have had different ideas of the trip and difficulties and have got thus far, and the thoughts of their wives or lovers enter their noodle and they set up a howl and strike a bee line home." Some pioneers often tried to wrangle "wicked steers" that "had never saw a yoke." When Wood and others tried to hitch these wild beasts to the wagons, the massive animals bolted, with "every man

${ }^{63}$ Lucrena Parsons, June 19-July 18, 1850. 
hanging to a rope fastened to each steers horns. That was enough to make all the world laugh. ${ }^{\circ 4}$ Adrietta Hixon recalled the immense amount of work and a comment from a son to his father, "We are doing nigger's work." 65

If cholera and inexperience were not enough, the scarcity of food proved up to the task of destruction on westward journeys. Thomas Christy wrote near Lassen's Meadows, California that they encountered "starving emigrants begging for provisions. There is some that is tetotelly out; others say they have not tasted meat for fifteen days; some complaining of being verry weak with hunger; some of them that is suffering or complains of suffering we divide with but if we was to listen to all we would not have a mouthfull of provisions in two days. God only nows what they are to do." ${ }^{96}$ Noticing a line of dead horses, mules, and oxen on the roadside, Eleazer Ingalls noted that "hams cut out to eat by the starving wretches." She resolved, "I will eat the lizzards which infest the sage bushes, before I will eat the stock that died from alkali."${ }^{967}$

Dead animals were a constant feature of the road west. Margaret Frink, who traveled later in the year, described growing accustomed to abandoned property and dead animals that her company passed: "Both sides of the road for miles were lined with dead animals and abandoned wagons. Around them were strewed yokes, chains, harness guns, tools, bedding, clothing, cooking-utensils, and many other articles, in utter confusion."

${ }^{64}$ John Wood, April 1850.

${ }^{65}$ Lillian Schlissel, Women's Diaries of the Westward Journey (New York: Schocken Books, 1982), 25.

${ }^{66}$ Thomas Christy, July 16, 1850.

${ }^{67}$ Eleazer Ingalls, July 31, 1850. 
As she continued it got worse. "The dead animals seemed to become at every step of the way more numerous. They lay so thick on the ground that the carcasses, if placed together, would have reached across many miles of that desert. The stench arising was continuous and terrible." ${ }^{98}$

The elephant kept rearing its head. At the death of a fellow traveler named Robert Duncan, John Wood wrote, "Oh! the dying bed is a solemn scene on these desolate plains. I have not seen a man yet who has not regretted that he ever started on these endless 'ups and down." ${ }^{69}$ After experiencing the death of three more men just west of Fort Kearny, Nebraska, Wood wrote, "We are not alone, in this calamity, thousands are around us sharing the same fate. The sick and the dying are on the right and on the left, in front and in the rear and in our midst. ... Hundreds are on their way home, faint hearted and terror stricken. ${ }^{70}$ Sophia Lois Goodridge recorded the names of five of her compatriots that died between June 26 and July 7, including one nineteenth month old. ${ }^{71}$ George Bonniwell wrote of trouble in 1850 about a series of problems. "A most awful road: stone and rocks an the dust so bad, we could not see our train...Water scarce, grass scant. Drove 28 miles and camped on the river bottom. Had to ford the river for grass. This is a trying time to the men and horses. I have just been to get grass, and got up to my

${ }^{68}$ Margaret Frink, August 16, 1850.

${ }^{69}$ John Wood, June 10, 1850.

${ }^{70}$ John Wood, June 8, 1850.

${ }^{71}$ Sophia Lois Goodridge, June 26-July 7, 1850. 
'tother end' in mud; I did not know whether I should [ever be able to] get out. First glimpse of the Elephant."72

Though migrants brought much with them, one of the casualties for some was Victorian norms and customs. Charles Ross Parke crossed paths with a pretty young woman, probably around age sixteen, in Marysville, California. Wearing a Spanish sombrero, pants, red sash, and shorter hairstyle, Parke wrote, "She bets freely on horse races, talks much with the miners, and finally gets drunk." Originally from Boston, the woman abandoned her father to take up with a gambler. Now, "she deals monte nicely, swears, and smokes cigarettes." 73

Not all was bad on the trails, as some delighted on the wonders of the West. William Fowler Pritchard came across a small, brownish bird while his camp ate breakfast in Idaho. The bird seemed to have grown accustomed to the pioneers of 1850 , so much so that he considered it "tame." Though some in his party wanted to keep it, Pritchard concluded that "it would have been very cruel to deprive it of its liberty, a thing dear to us all." 74 Catherine Sager wrote of the first encampments that "seemed to us we were living within a traveling circus." Still a child, Sager wrote of the excitement, "The long lines of wagons stretched as far as we could see in front and as far as we could see behind. They were every shape and color. Those who could not afford the better wagons often brought their farm wagons and covered them as best they could with canvas cloth. Some were painted with slogans, some with animal designs. Goin' to See the Elephant!

\footnotetext{
${ }^{72}$ Hunsaker, xvi.

${ }^{73}$ Charles Ross Parke, April 25, 1850.

74 William Fowler Pritchard, August 12, 1850.
} 
they read. All sought their proper places in line; nobody wanted to be last. The yokes of oxen strained and bellowed, the wagon wheels and beds creaked and jolted and groaned. People of all descriptions milled around us, speaking in ways peculiar to their places of birth. Everywhere, everywhere, there was the excitement known as 'Oregon Fever."'75 John Wood wrote of enjoying a meal in Salt Lake City with Mormons, noting "my heart was filled with gratitude. ${ }^{76}$ Another John, John H. Robinson, experienced similar treatment in the city. He dined at a bowery filled with happy people. He wrote that there "were some good toasts drank, and some first rate songs sang; but not the least interesting part of this large assembly were the ladies, of whom there were some very handsome." A band played and they engaged in some "first rate" dancing, and later in the week "crossed our Jordan and was again on our weary way to the land of gold." ${ }^{.77}$ Sara Davis wrote of a type of prickly pear that grew in large numbers outside of Fort Kearny, Nebraska. Though the mosquitoes bothered her, she remarked that the flower "was beautiful as any flower I ever saw." ${ }^{178}$ Rio Jean Baker wrote of another insect after an "evening after the rain cleared we saw myriads of fire-flies, the first we have ever seen, and I thought them the most beautiful natural phenomena, I had ever beheld." 79

Often tragedy met with a dark form of humor, which made dealing with the elephant a little easier. Eleazar Ingalls witnessed a "perfect tornado" while traveling

\footnotetext{
${ }^{75}$ Hunsaker, 111.

${ }^{76}$ John Wood, July 27, 1850.

${ }^{77}$ John H. Robinson, July 24, 1850

${ }^{78}$ Sarah Davis, June 12, 1850.

${ }^{79}$ Rio Jean Baker, May 21, 1851
} 
through Nebraska in May 1850. Tents were sent flying while the pioneers attempted to wrestle them back down. Ingalls recorded in her diary that "in truth it was one of the most delightful scenes of confusion, turmoil and dismay that could be imagined." An event that "would have made a parson split his sides with laughter if he could have refrained from holding the hair on his own head long enough to laugh." 80

By the time the door was closing on the 1840 s the route west seemed wide open. Certainly, dangers and accidents were never over, and it still took a special type of person to set off to Oregon, California, or Santa Fe. However, the destinations were all set. The needs were known. And most the trails had been used so frequently that for long stretches many adventurers would start to consider them roads. Within Missouri, the city of Columbia had established a college and the roads to Kansas City had become improved and established. Steamboats were a common occurrence as shipping prices dropped and the railroad and stagecoach were not far away. William McCoy wrote from Independence in 1848 that "almost everyone in coming to this country [Missouri] becomes infected and rests uneasy until he has completed the great achievement of going to Mexico." He had concluded that the Santa Fe had become "a beaten highway the whole distance $\&$ so much travelled, that it is a tame affair." 81

However, the 1850's would not bring unbridled prosperity on the trails. Whereas the West teemed with opportunity, a great American sin in the east would rear its ugly head.

${ }^{80}$ Eleazar Ingalls, May 25, 1850.

${ }^{81}$ Eugene T. Wells, "The Growth of Independence, Missouri, 1827-1850," Bulletin of the Missouri Historical Society, XVI (October 1959), 42-43. 
Chapter Two - Establishing the Elephant

By the time Horace Greeley had termed the phrase "jumping-off place," the excitement for the West had been growing for some time. ${ }^{82}$ On July 4, 1850, the famed playwright David G. Robinson staged the play "Seeing the Elephant" at the Dramatic Museum in San Francisco. ${ }^{83}$ A burlesque comedy about the Gold Rush, it satirized the men who were tricked into making the journey to California. It was a smashing success. Death and deprivation still stalked the thousands that would take to the trails, but the enthusiasm of the travelers did not seem to be waning. Amelia Hadley and her company, for example, were supposed to have a day of rest on June 6,1851 , just on the north side of the Platte River, "Some of our company did not lay by and have gone on they are anxious to see the elephant I suppose." $" 84$

Three major shifts in patterns of western migration occurred in the first half of the 1850s. First, more and more families began taking the trip not as gold seekers but as settlers to California and Oregon. Second, due to the growth of steamboat traffic that could ferry migrants farther along the trail to places like St. Joseph and Council Bluffs, while Kansas City, Westport, and Independence lost some of their outfitting traffic. To what degree is unknown, as many migrants that "jumped off" farther north often still recorded stopping in the cities. Third, Kansas City businesses were able to still maintain much of the trade traffic to the growing Santa Fe market. Finally, the trails got more efficient and safer, despite the diseases and worldviews that migrants brought with them.

\footnotetext{
${ }^{82}$ Unruh, 94.

${ }^{83}$ Rea, 21.

${ }^{84}$ Amelia Hadley, June 6, 1851.
} 
By the $1850 \mathrm{~s}$, there were around five major jumping off points for migrants to Colorado, California, or the Pacific northwest established and were commonly used near the Missouri River—Kansas City, Independence, Fort Leavenworth, St. Joseph, and Nebraska City. Although the northern and southern jumping-off towns were separated by 250 miles, they tended to coalesce around Fort Kearny, Nebraska, which served as the de facto beginning of the "Great Platte River Road" that took most overland journeyers across Nebraska to the west. ${ }^{85} \mathrm{~A}$ sixth jumping off point also had gained popularity around Council Bluffs, Iowa that had been operating since 1847 during the great Mormon exodus on the north side of the Platte River. Far more non-Mormons had taken the route by the $1850 \mathrm{~s}$. The premier historian of the trail systems, Marrell J. Mattes, estimated that of half a million known migrants between 1841 and 1860, around 165,000 used the Council Bluffs Road, with peaks during the discovery of gold in California and during the Pike's Peak Gold Rush in 1859.

One must be careful with the numbers of people that were crossing through each town. Of course there was no scientific study or anyone with a clicker keeping a good count. Furthermore, many of the emigrants passed through multiple cities, which makes calculating migrant totals via adding town estimates unreliable. Numbers, especially those published in newspapers or written for broader publication, also clearly had ulterior motives. The Gazette in St. Joseph would benefit greatly if it became nationally known as a port of call in comparison to the town's rivals in Independence or Westport. More migrants meant more money, not only for the newspaper sales but also for the area

${ }^{85}$ Merrill J. Mattes, "The Council Bluffs Road: Northern Branch of the Great Platte River Road,” Overland Journal 3, no. 4 (Fall 1985), 30. 
businesses that were advertising in the newspaper. E. W. Roberts of Illinois read the Gazette estimate of 8,000 people going through Independence but had his own belief that the number was probably around 5,000. He wrote in the St. Louis newspaper The Daily Reveille, "There is a great disposition to overrate all these things, yet the number is most extraordinary. $" 86$

Overland migration tended to be seasonal as trains moved in the spring. Advertisements in the St. Louis Daily Missouri Republican tended to showcase luxury goods such as watches, jewelry, books, and food supplies during the winter months. During the California gold rush, the newspaper shifted in the spring to try to capitalize on the migration before travelers made it to the jumping off towns. Wagons, gold mining equipment, livestock, harnesses, dry goods, and assorted traveling materials became the call of the day. ${ }^{87}$ One traveler, who wrote from Fort Kearny believed the migration of 1852 was as sizable as the gold rush years. "We could see the road for miles ahead, showing one continuous line of covered wagons, while every ravine was filled with tents, and every bluff covered with flocks of sheep, or droves of cattle. The bulk of the emigration is behind us. Thousands are passing along the north side of the Platte. It is believed the emigration will be equal to that of $1849 . " 88$

The Cleveland Plain Dealer wrote of the hundreds of migrants departing the Western Reserve, but noted the diversity coming from places across the Union. "But the

${ }^{86}$ Barry, 843.

${ }^{87}$ Harmon Mothershead, "River Town Rivalry for the Overland Trade," Overland Journal 7, no. 2 (Summer 1989), 15.

${ }^{88}$ Barry, 1082. 
stampede is not confined to this district, by any means. News from Michigan inform us that the farmers complain greatly of the high rates of labor, occasioned by the depopulation of that State from the same cause... The Hoosiers, too, are not a whit less panic stricken. A large emigration is now flowing thence to California from Dearborn county in southeastern Indiana. A Baptist colony, a Presbyterian colony, and divers of other colonies are girding themselves up in different parts of the State for an exodus to Oregon. The emigrants are mainly farmers and mechanics — the finest of stock." 89 Julius Froebel was a veteran traveler not only on various western trails, but also down to Central America and Mexico. In summer 1852, he set off from Independence with a Messrs. Mayer and Company wagon train that consisted of around 20 wagons with ten mules apiece. Destined for Chihuahua, Mexico, his letters were later published in the New York Daily Tribune. He described Independence as "a small town, with the character of a frontier place engaged in an extensive carrying trade....The town is surrounded by wheelwrights' shops, large premises filled with new wagons, painted red, green, or blue, and the whole trade of the place consists in supplying the wants of trading and emigrant caravans, which start from this and from a few other stations on the Missouri, for New Mexico, Utah, California, and Oregon." He then noted the growth of nearby Westport, which had grown large enough to challenge the "monopoly." 90 Still, Independence had 1,600 inhabitants, thirty dry goods stores, two large hotels, multiple boardinghouses, twenty wagon and blacksmith shops, a hat maker, two gunsmiths, two

${ }^{89}$ Herbert Eaton, The Overland Trail to California in 1852 (New York: Capricorn Books, 1974), 1.

90 Barry, 1117. 
tin shops, and three druggists..$^{91}$ Between 1848-1853, trade with Mexico averaged $\$ 1,138,000$ annually, about a quarter of the total trade with the country. ${ }^{92} \mathrm{~A}$ Mr. Lunt, who recently arrived to Independence from Salt Lake City on August 22, 1854 estimated that 150,000 cattle had been driven to California that year. ${ }^{93}$

A correspondent in Independence for the New York Daily Tribune reported that traffic in early May 1850 through the town had slowed. "For some unknown cause, this town is extraordinary dull this season; as yet, compared to last season there are but few California emigrants here. The prospect is quite discouraging for an early start. ${ }^{{ }^{994}} \mathrm{St}$. Joseph was bustling, however, with an estimated 8,200 arrivals. ${ }^{95}$ John Wood of Ohio wrote in his journal "The excitement here is almost alarming. There are now about 10,000 emigrants in this place and all are hurrying to make a start. ${ }^{\prime 96}$ By April 26, the Gazette estimated that the number had risen to 15,000 with steamboats arriving at the port three or four times a day carrying three or four hundred people each $\cdot{ }^{97}$ Over a three-

${ }^{91}$ O’Brien, 51-52.

${ }^{92}$ O’Brien, 65.

${ }^{93}$ Barry, 1201.

${ }^{94}$ New York Daily Tribune, May 3, 1850. Barry, 915.

${ }^{95}$ St. Joseph Gazette, April 12, 1850. Barry 915.

${ }^{96}$ Barry, 915.

${ }^{97}$ Barry, 918. In historian's Louise Barry's analysis of 101 trail diaries of known emigrants, 63 jumped off at St. Joseph, while 38 probably left Independence or the Westport area. Barry, 860. 
day period, the steamboat Alton ferried around 7,563 cattle, 382 horses, and 212 wagons across the Missouri at St. Joseph. ${ }^{98}$

Midway through the beginning of the travel season of 1852, the St. Joseph Gazette expounded on the great trade going through the city on their way to California and Oregon. They estimated that the traffic would be greater than that of the early gold rush. A man coming from Hannibal reported that the road in their direction was "crowded with teams, and hundreds are daily crossing the Mississippi at various points.” The ferries were full of migrants with little prospect of them drying up. Then the newspaper reported on a disease sweeping the people. It was not tuberculosis, cholera, typhus, or even cowbell. It was the "California fever:"

Having been attacked by that dangerous disease called the California fever, and subsequently thoroughly cured, I submit the following cause, symptoms, prevention and cure, hoping others may profit by my experience. Cause.-An inordinate desire to become rich; a belief in the golden stories which are circulated by the newspapers and otherwise.

Symptoms. - A restlessness of mind and body; opening wide the ears to the brighter side of the picture, and closing both eyes and ears to the darker side; breaking up housekeeping, and sending wife and babies to grandma's; selling good notes at thirty per cent discount, or other property at half its value. Prevention.- - Let reason predominate over avarice, and benevolence over selfishness; love security rather than danger, and the endearments of home rather than a life of toil and suffering. ${ }^{99}$

The "fever" had taken over the nearly seventy thousand migrants who crossed the continent that year. St. Joseph was trying to service them all. John Clark of Virginia wrote from the deck of the Midas about the growing throngs gathered at St. Joseph, "On nearing the City it shows a glowing front with high bluffs or baren banks to the rear.

98 St. Joseph Gazette, April 13, 20, 1853.

99 St. Joseph Gazette, April 25, 1852. I wish to apologize for the imprudence of the St. Joseph Gazette. However, I take pride in the cowbell comment. 
These, with the rich valley below are dotted with waggons, tents, horses, mules \& other stock to the number of 20,000 with a great portion of other equipage." The sight was "seldom seen by one so old, or during a life time."100 Lodisia Frizzell of Illinois complained of the great wait at the ferry, as there were too few working as fast as they could. A great vexation was felt among the crowd, as many were forced to wait in line sometimes for a couple of days the whole time worrying about others cutting in line. ${ }^{101}$ Many were like Moses Laird that planned to depart from St. Joseph, but instead went up the river ten miles north to Savannah to make the crossing. ${ }^{102}$

Kansas City had lost some of its overland migrant traffic to St. Joseph and Council Bluffs following the initial gold rush years. On November 12, 1850, Dr. Wilson Hobbs and his wife Zelina along with their two children arrived as teachers to Kansas City. Wilson wrote later his first impressions: "We landed at Kansas City late in the afternoon.... There was standing near the landing a large brick building which had the appearance of a hotel. I afterward learned that it was built for such use during the more prosperous days of the early California emigration, and had for some time been abandoned. We soon learned there was but one hotel in the "city." He estimated that around 500 to 600 travelers left Kansas City and ventured to Westport, which had the "advantage in stir and businesslike appearance" over its "pretentious neighbor."103 The
100 Eaton, 21.
101 Eaton, 23.
102 Eaton, 25.
${ }^{103}$ Barry, 974. 
bleak report of the missionaries could give the impression of a city on the downswing, but this was wintertime when few migrants would have been there anyway.

Not all was lost, especially with the city still conducting an enormous amount of trade on the Santa Fe Trail. In the summer of 1850, Waldo, Hall and Company began operating a regular stagecoach service for the first time out of Kansas City to Santa Fe. Under contract to carry mail for the federal government, they also advertised personal transport wagons "in splendid style, and are each capable of conveying eight passengers. The bodies are beautifully painted, and made water-tight, with a view of using them as boats in ferrying streams." A $\$ 200$ one-way ticket included another wagon for provisions and camping supplies. Coaches were scheduled to set off bi-monthly and by 1860 they left once a week.

The Missouri Republican sang the praises of jumping off at Kansas City in April 1852 and even used a bit of nineteenth-century celebrity: "Finally, They [citizens of Kansas City] would say that all the largest and most celebrated jobbers in conducting trains across the Plains, universally start from Kansas [City] as the best and most convenient starting point, from which to make their trips, speedily, comfortably and safely. Aubry, Messervy, Huston, Kit Carson, and all the celebrated voyagers, invariably select Kansas as their starting point." ${ }^{104}$ Immigrants from England, Scotland, Wales, and Scandinavian countries started to come in larger numbers to join their Mormon brethren in Salt Lake City during the 1850s. A William Empey was charged to buy enough cattle

${ }^{104}$ Missouri Republican, April 8, 1852. 
for six thousand Mormon migrants who "design making Westport and Kansas [City] their outfitting and starting points. ${ }^{105}$

In his investigation of the Gold Rush years of 1849-1853, Mattes found a gradual shift to Council Bluffs as a preferred jumping off point. Of a series of extant "record keepers" he found a suggestive shift in the migration patterns to California or Oregon.

\begin{tabular}{|l|c|c|}
\hline & $\mathbf{1 8 4 9 - 5 3}$ & $\mathbf{1 8 5 2 - 5 3}$ \\
\hline Kansas City & 173 & 44 \\
\hline St. Joseph & 282 & 59 \\
\hline Council Bluffs & 312 & 168 \\
\hline
\end{tabular}

There are several possible explanations for this shift, most importantly being a change in the people who were making the trip itself. The gold rush tended to attract mostly men (an estimated 9 to 1 male to female ratio), but by 1852 the fever had died down for gold seekers and there was a returned enthusiasm for families of settlers began looking at Oregon. The number of women making the trek in 1852 and 1853 roughly tripled. Council Bluffs tended to attract migrants coming in covered wagons from eastern Iowa, Illinois, Indiana, Wisconsin, and Michigan. Most of these wagons had already been supplied or could find appropriate accommodations and goods in Council Bluffs, making the trip south to Kansas City or Independence unnecessary. And finally, the above table probably overemphasizes the migrants headed for Oregon or California rather than those who went to Colorado or to the Southwest on the Santa Fe Trail. That said, it does

${ }^{105}$ Barry, 1221. 
suggest that viable alternatives to jumping off in the Kansas City region had emerged to challenge either Westport or Independence.

By 1851, Council Bluffs was the jumping off point for an estimated sixty percent of overlanders. ${ }^{106}$ And with St. Joseph growing in importance, it would be easy to write off the other Missouri towns. However, this misses the overall growth of the regional economic system.

Gottlieb F. Oehler and David Z. Smith, Moravian missionaries to the Pawnee Indians, took note of Fort Leavenworth saying it "is a place of considerable business, in the way of furnishing military stores for the more western forts." Weston was also a "place of considerable trade." ${ }^{107}$ Native Americans located in the Kansas territory were still doing considerable business lower on the Mississippi River. Even the towns of Lexington, Weston and Liberty had grown largely due to hemp production. Indeed, every town seemed be growing and would experience more prosperity during every major boom year, and especially after 1854 when the rush to Kansas commenced.

Mary Stuart Baily’s trail diary in April 1852 also should caution historians who claim exclusivity for "jumping off" points. Though technically she would launch from St. Joseph, she stopped in Wayne City on the Missouri where she found "Some very romantic spots resembling more Walter Scot's descriptions of Ben Vanait in his Lady of the Lake." At Independence landing she saw the first of many California tents and a brisk trade, "Here we saw Santa Fe traders with their heavy wagons, long whips, dirty clothes.

106 Diana L. Ahmad, Success Depends on the Animals: Emigrants, Livestock, and Wild Animals on the Overland Trails, 1840-1869 (Reno: University of Nevada Press, 2016), 19; Unruh, 98.

107 April 1851. In Barry, 992. 
Here we saw any quantities of buffalo robes \& everything for immigrants." ${ }^{108}$ The next day she went through Weston, "a flourishing place, early in the morning" and arrived at the City Hotel of St. Joseph in the evening where she was "indifferently accommodated" while her wagons and cattle were "encamped 3 miles out of town."109

In 1852, the St. Joseph Gazette reported the major shift towards families. "We notice among the emigrants several families, who go out with the intention of making permanent settlements. The ferries at this city, are crossing large numbers every day, who are making arrangements to leave in a short time." ${ }^{110}$ In a letter from Harriet Augusta Stewart to her cousin in Oregon, the fifteen-year-old wrote in excitement about what Oregon had in store for their trip in 1854. She would be traveling with neighbors and family and wrote of how she wanted to see buffalo and hear the wolves howl. Then, the letter switched into what excited the other young people. In the party was Margaret Sutton who wanted to see her brother in Oregon, Mary Melissa wanted to ride a pony, Amos Stewart wanted to hunt, and Franklin A. Stewart wanted to see mountains and smell the sea breeze. But it was Jim Sutton, who had previously been to Oregon and back to Illinois, who gave the most entertaining response. The thirteen year old wrote:

I Jim Sutton want to go to Oregon to find a place where I can get ride of these troublesome ge-hals [gals?], for they are more torment to me than forty head of stray ducks, they tease me from the time they open there eyes in the morning til they close there eyes to snore me a tune of peace. they beat me with rotten aples, bang me over the head with the dishrag.- - If I do nothing but tear up an old dirty apron, although it may have a dozzen holes in it my poor head pays for it at the rate of twenty cts a yard. O! miserable being that I am! when shall my troubles

108 Sandra L. Myres, ed., Ho for California!: Women's Overland Diaries from the Huntington Library (San Marino: Huntington Library, 1980), 53.

${ }^{109}$ Myres, 54.

110 St. Joseph Gazette, April 25, 1852. 
have an end-All that read my tale of sorry pitty me. Written by request and beaten for it at that. Yours truly J. M. Sutton.

Jim Sutton would arrive in Oregon despite the women in his party. He would marry in 1867, and later gained notoriety as the person who named Crater Lake in Oregon. ${ }^{11}$

One of biggest changes for trade and overland migrants in the 1850s was the increased presence and efficiency of steamboats. Charles Deatherage wrote that the $1850 \mathrm{~s}$ were the "golden era" of steamboats on the Missouri River. ${ }^{112}$ In 1841, twenty-five steamboats operating on the Missouri River transported around 46,000 tons of freight. By the end of the decade that number had expanded to around two thousand boats and steamboats. By the 1850 s that number grew to three thousand. ${ }^{113}$ In 1850 , the chief engineer of the Pacific Railroad, James P. Kirkwood, estimated that the Missouri River was moving 83,000 tons of freight and 107,000 passengers that brought in receipts of $\$ 450,000$ and $\$ 368,000$ in both directions. ${ }^{114}$ In 1841 , the trip from St. Louis to Jefferson City (168 miles) took around 40-48 hours. By 1853, the 309-ton Polar Star took 68 hours to go from St. Louis all the way to St. Joseph (565 miles). ${ }^{115}$ Steamboat operators also proved malleable to routes, meaning that boats that usually operated on the Ohio, Mississippi, Arkansas and Illinois rivers could be seen on the Missouri transporting

${ }^{111}$ Kenneth L. Holmes, ed., Covered Wagon Women: Diaries and Letters from the Western Trails 1840-1890, Vol 7 (Spokane, WA: Arthur H. Clark Company, 1989), 1825.

\footnotetext{
112 Deatherage, 417.

${ }^{113}$ Ahmad, 18.

${ }^{114}$ Lass, 61.

115 Lass, 49.
} 
goods from St. Louis to western ports on the river. ${ }^{116}$ The increased freight also meant that more migrants, animals, and goods could be moved cheaper to places farther up the river like St. Joseph and Council Bluffs. While making migration easier, it also eased stopping in outfitting towns like Independence, Kansas City, and Westport more convenient. ${ }^{117}$

The dramatic growth and trade over the Oregon-California and Santa Fe trails benefited mightily by the influence of the American government. At a time when the federal government remained relatively small (the largest department was the postal service), the government invested serious money in private interests and to protect and improve service on the various roads west of the Missouri River. For instance, the United States contracted with three businesses to carry mail west. Jacob Hall was to coordinate travel between Independence and Santa Fe once a year for \$10,990. William M. F. Magraw and John E. Reeside from Pennsylvania were contracted for once a month from Independence to Salt Lake City at $\$ 14,440$ per annum. A shorter circuit operated by Reston Roberts went daily from Independence, Westport, Weston, Dekalb, Sparta, and St. Joseph. Charles A. Perry, of Perry \& Young, Weston, Missouri, was awarded a contract to provide 225 horses to San Francisco at $\$ 270$ each on March 4, 1854. ${ }^{118}$ The government contracted with Jos. O. Sawyer to construct a barn and two cottages on April
${ }^{116}$ Lass, 58.
${ }^{117}$ Ahmad, 21.
${ }^{118}$ Barry, 1195. 
15,1852 , giving Sawyer $\$ 5,365$ and the stone and hardware. ${ }^{119}$ A. G. Hale also got a military contract at Fort Scott to supply 75 tons of hay for an estimated $\$ 255 .{ }^{120}$

The military provided protection for some trail routes, depots, and occasionally on some freight carriage. During the 1850s, 90 percent of the United States Army was stationed west of the Mississippi. ${ }^{121}$ Migrants who started out late or encountered misfortune could find shelter in one of these forts throughout the winter. In 1850, around 400 dragoons were dispatched from Fort Leavenworth to Santa Fe. One recruit named James A. Bennett and others reported how cholera had affected his unit. On August 3, he wrote: "Cholera raging to an awful extent among us. Men at active pursuits one day...; the next day they are a loathsome mass, thrown coffinless into the yawing pit. We wrap 4 to 5 daily in their blankets, and throw their remains in the ground with a blessing or a prayer. No stone marks their last resting place." Desertion became increasingly rampant. ${ }^{122}$ In May 1851, the First Dragoons under the leadership of Brevet Colonel Edwin V. Sumner provided a military escort from Fort Leavenworth all the way to Santa Fe with 87 horses, 386 mules, 60 wagons, a traveling forge, an ambulance, 22 stallions, and two wagon floats. ${ }^{123}$ When a man named Jones jumped off at the city of Kansas, Pawnee Indians attacked him and his party outside of Fort Kearny; the Indians were well

119 Barry, 1077.

120 Barry, 1114.

${ }^{121}$ Unruh, 201.

122 Barry 955.

${ }^{123}$ Barry 1003. 
armed and outnumbered the whites ten to one. Immediately, the military was dispatched and were "in pursuit of them."124

Despite the reach of the military, it did not possess enough wagons and manpower to dispatch the large amount goods to resupply the various forts on the frontier. Instead, the military contracted with private individuals often to transport goods along the trail, especially from Fort Leavenworth. Between February 23 and March 6, 1850, the army contracted multiple people and businesses to transport goods from the fort with large sureties down various western trails. These contractors included David Waldo (Fort Laramie), Joseph Clymer of Westport (Santa Fe), James Brown and John S. Jones (Fort Hall, Idaho), David Waldo (El Paso del Norte). The Assistant Quarter Master paid between $\$ 7.74-\$ 14.15$ per 100 pounds. ${ }^{125}$ Though some of the receipts were lost and it is not clear how much cargo the U.S. government paid for, Waldo carried 97,592 pounds to Fort Laramie and 236,669 pounds to Santa Fe for an estimated $\$ 7,553$ and $\$ 31,879$ respectively before expenses. ${ }^{126}$ Two more contracts were secured that fall with Waldo and the Brown, Russel \& Co. with sureties that totaled \$250,000. ${ }^{127}$ Benjamin Holladay of Weston, Missouri, secured a two-year contract to transport army goods to forts Kearny

${ }^{124}$ Daily Intelligencer (St. Louis), August 13, 1851.

125 Congress Globe, 31 st Congress, 2nd session, H. E. Doc. No 23. In Barry, 901903.

${ }^{126}$ Congress Globe, 32nd Congress, 1st session. Sen. Ex. Doc. No. 1. Barry, 952, 955.

${ }^{127}$ Barry, 964-965. These contracts tended to occur early often in the early part of the year. Other examples include deals with John S. Jones and William H. Russell (Santa Fe, February 17, 1851); Perry and Young (Fort Mackay, March 10, 1851); Joseph Clymer (El Paso, April 18, 1851). Barry, 980, 982, 985, 991. 
and Laramie, which at $\$ 3.80$ and $\$ 6.80$ per 100 pounds, resulted in a gross profit of $\$ 12$, 232.76 the first year alone in 1851 .

On July 1, 1850, the Waldo, Hall \& Co. set off as one of the first stagecoach companies to deliver regular monthly mail from Independence to Santa Fe, New Mexico. This company had previously worked with the government with regard to freight transit, and it now managed to secure a fairly lucrative contract. Guided by ten men, one of whom told the New York Tribune, that they were "well armed, all resolute fellows, except two young cadets from Fort Leavenworth, who have yet to be tried. If we meet the Apaches we are determined to give them $\mathrm{h}$ _ll or die in the attempt. If not scalped you will hear from me." The Missouri Commonwealth gave more detail of the company's eight passenger vehicles and the operators bragged that they would be able to discharge "one hundred and thirty-six shots without stopping to load!"128 The government also contracted with steamboats (James H. Lucas, Polar Star, Sonora, Isabel, Edinburg, Delaware, Clara) to transport five hundred men from St. Louis or Alton, Illinois. ${ }^{129}$ Another contract was made by the military with Alexander Majors and William H. Russell to carry army supplies from Fort Leavenworth to Albuquerque in the summer 1854 at a rate of $\$ 10.83$ per 100 pounds. ${ }^{130}$

Death and the trails have become synonymous in more recent years. However, the trail system by the 1850 s was safer and easier than ever before. Indeed, the dangers increasingly had less to do with the environment, but more to do with the environment
${ }^{128}$ Barry, 949-50.
${ }^{129}$ Barry, 1204.
${ }^{130}$ Barry, 1206. 
the migrants created. The most common sentiment found in travelers' diaries during the 1850s is boredom, not an overwhelming fear of dying. Certainly, it remained dangerous, but only relative to today. Estimates of death along the trail from 1840 to 1860 range from 12,000 to 30,000 , though calculating a more specific number remains difficult. In some cases, deaths could be recorded by more than one source. More likely, deaths were not recorded at all. Richard Rieck's analysis of disease on the trail notes that a significant proportion of death occurred within one hundred miles of the various jumping off points along the Missouri River. One group of travelers, including Alonzo Delano and John Christian, attempted to record every grave marker on their trip and confirms this assessment, though Delano died of the very same disease. Cholera on the trail through Nebraska was five times deadlier than the one through Kansas. Cattle on the other hand tended to die later in the voyage, possibly due to overwork and change in vegetation. One emigrant estimated that oxen died at a rate of eighteen to one in comparison to their human counterparts. In general, however, deaths declined in almost every category except Indian warfare between the 1840s and 1850s. ${ }^{131}$

Cholera was perhaps the most feared and widely reported disease that afflicted those on the plains. Occasionally translated as "flood of bile," the diseased could be well in the morning and by nighttime have symptoms of vomiting, diarrhea, cramps, clamminess and shrunken features. Once contracted, the disease had a mortality rate of around fifty percent. ${ }^{132}$ Most were dead within two days due to dehydration and victims

${ }^{131}$ Richard L. Rieck, “A Geography of Death on the Oregon-California Trail 1840-1860," Overland Journal 9, no. 1 (Spring 1991), 15-20.

${ }^{132}$ Charles E. Rosenberg, The Cholera Years: The United States in 1832, 1849 , and 1866 (Chicago: The University of Chicago Press, 1962), 3. 
reportedly turned blue with "rice water stools" that caused some to lose consciousness. Three contemporary major theories abounded. Historian of medicine Shauna Devine wrote: "The anti-contagionists believed the disease was caused by some kind of poison or immaterial influence that would infect a susceptible body, and its propagation was tied to the environment." In effect it was a poison caused by the environment. She continued, "Contagionists on the other hand believed the disease was produced in the bodies of sick people, transmitted by exhalations and inhaled or ingested by healthy people, who then became sick. Others still were contingent contagionists and believed that transmission was dependent on factors such as individual susceptibility, class, habits, filth, race, weather, diet, the virulence of the virus, and local factors." ${ }^{133}$ Travelers at the time simply did not know that cholera was caused by a microorganism called Vibrio cholerae, the bacteria was spread due to unsanitary water supplies along the trail that were used for drinking and excrement. This caused outbreaks nearly every year in one or more of the jumping off points. The best cure, rehydration, simply was not an option. Though some progress was made with regard to treatment during the Civil War, it was not until the late 19th century that it became better understood. Cholera thrived only because of the enormous numbers of people, especially in cities with large emigrant populations, that also lacked the infrastructure to dispose of waste. There was an outbreak of cholera in the city of Kansas and Independence in April 1849, resulting in the deaths of at least twentyfive in one week. The New Era newspaper in St. Louis estimated that perhaps ten people a day died of the disease including Isaac McCoy, whose father was one of the principal

${ }^{133}$ Shauna Devine, Learning from the Wounded: The Civil War and the Rise of American Medical Science (Chapel Hill: The University of North Carolina Press, 2014), 216-217. 
organizers of the city of Kansas. The primary victims according to the townspeople were the emigrants to California, and less the people who were citizens of the town. ${ }^{134}$ In 1852 , cholera struck at Westport resulting in forty-eight deaths in one day with forty more recorded in Independence and another twenty in Kansas City. It is not a coincidence that 1852, the largest year of migration, also had one of the most devastating cholera outbreaks on the trail. Ezra Meeker estimated that nearly five thousand died that year alone. ${ }^{135}$

By the 1850 s, doctors became increasingly common on the trail, though they could do very little when it came to cholera or other diseases. This led to an increased belief that they were charlatans, which was not always wrong. One caravanner on the Santa Fe reported seeing burning barrels of tar on every street corner because it was believed that cholera could be eliminated by killing it with smoke. Other remedies included whiskey, red chilies, bitters, antibilious powders, avoiding cucumbers, and too frequent bathing. ${ }^{136}$ Lucy Rutledge Cooke wrote in her diary about a doctor coming to visit her company to deal with some cholera patients. When two men died the next day, the doctor said it was because "they had nothing with them to eat but bacon, hot bread \& coffee as juice, beans, pickles or anything of that kind necessary on such a journey." Despite seeing death in person, she wrote, "We hear much of the cholera but I think generally speaking people frighten themselves into it for where we have so much pure air

${ }^{134}$ Barry, 830-831.

${ }^{135}$ Ezra Meeker, Personal Experiences on the Oregon Trail: The Tragedy of Leschi (1852, Seattle: Meeker, 1912), 28.

${ }^{136}$ Marc Simmons, "The Old Santa Fe Trail, Part II," Overland Journal (vol 4 no 3 Summer 1986), 64. 
I cannot see how folks can catch anything of the kind." 137 Ignorance of disease also may have been self-selecting. Some doctors believed the cure for tuberculosis, or "consumption" as it was known, was actually to take a trip to get fresh air. This sent many already sick people on the trail. ${ }^{138}$ Mary Rockwood Powers wrote of "The Doctor" that was part of her company in her journal. Though he promised to do the cooking, he did not, and she found him to be a "perfect shark." She was so tired that she laid down and "could not help the tears from flowing." Later, the doctor informed his travel mates that he was going to go on by himself. He began raving, to which the company pled that they had done all they could for him and his family. A Mr. Hendrick called him a "knave and a black-leg." He said that the doctor's wife was a "perfect lady" that he pitied for having to live with "such a fool and madman as he was." Writing this story in her diary about her husband, "The Doctor," the reader can assume that the marriage did not last.

The disease did not affect all equally. Native Americans had been devastated by disease for decades, but the arrival of so many migrants also brought the cholera epidemics of the east right to their doorsteps. One Sac and Fox chief reported that cholera had ravaged his 2,000 person tribe, killing 10\% in only one outbreak in May 1849 . They left the dead unburied and fled so as to avoid further contamination. Jotham Meeker, who wrote from the Ottawa Baptist Mission in present day Franklin County, Kansas, that they were surrounded by the disease. Reports came from the nearby Miami, Shawnee, Delaware, Wyandotte, Kickapoo, Pottawatomie, Iowa, and Kansa tribes that "Cholera

${ }^{137}$ Lucy Rutledge Cooke, May 31, 1852.

${ }^{138}$ Myres, 42. 
rages with great violence." ${ }^{139}$ Indian agent John E. Barrow reported that during the same spring and summer, nearly 1,200 Pawnees had died from cholera alone. Combined with warfare, nearly a quarter of the tribe died in just six months. ${ }^{140}$ In 1850, the Indian Agent J. R. Chenault hired Dr. Edwin R. Griffith to inoculate 1,700 Sac and Fox against smallpox, resulting in 40 deaths. A few month later, Chenault reported that the Foxes "are yet suffering from this disease, and have... scattered in every directions" resulting in the deaths of over 300 tribesmen. ${ }^{141}$

Beyond disease, the ecological damage caused by the migrants had dramatic effects. Roads became so worn down that their imprints can still be seen today. Previous migrants of the 1840s had already wiped out most of the nearby trees for repairs and firewood in certain areas on the trail. During his trip in 1852, Willis Boatman spelled out the problem, "Finally the cholera subsided, but then came another difficulty for those that were behind...that was feed for their teams....There were certain camping places that we all had to make in order to get water. So, of course we parties that had sickness in our trains got behind and the result was our teams nearly died."142 After it has been heavily grazed, grass can generally regrow in three to six weeks to replenish the roots and crown. But, if eaten again before regrowing and replenishing, the grass dies. Even more concerning is that animals tend to search for lush green regrowth, which means even in

${ }^{139}$ Barry, 865.

${ }^{140}$ John E. Barrow, Commander of Indian Affairs Report, 1849. Barry, 890.

${ }^{141}$ Commissioner of Indian Affairs, Reports, 1851, 1852. Barry, 1002.

142 Weldon Willis Rau, Surviving the Oregon Trail 1852: As Told by Mary Ann and Willis Boatman and Augmented with Accounts by other Overland Travelers (Pullman: Washington State University Press, 2001), 77. 
places with rich nutrition, the grass will soon become replaced by less nutritious plants. ${ }^{143}$ With thousands of oxen, mules, horses, and cattle crossing over the same trails and outside of towns, this became a serious issue, especially for those coming later in the travel season due to overgrazing. One emigrant that had left later in the season in 1852 reported that after Fort Kearny he was forced "to leave the road, frequently five or six miles to get sufficient grass for his animals." 144 The St. Joseph Gazette worried in late April 1852 about the hundreds that would be taking to the plains, "but how their stock is to subsist, is a mystery to us, as there is not yet a particle of grass on the plains."145 This, combined with the general overwork of animals, contributed to an enormous amount of animal attrition. John Clark wrote from the Humboldt Sink in Nevada, "The smell of the dead stock \& rotten water is strong, \& we moved down to the lower end of the Meadow. Here the stench is still worse. The dead cattle is sweld to enormos size, \& just fire a bullit into the carcase $\&$ you will see how quick the emigrants near by will pull up and leave. Not a man of us could eat diner or supper at this place." 146 This of course led to more contamination, and with it, more disease.

The example of the Lantz Party demonstrated how all of these factors combined to make the trail dangerous. Daniel Lantz of Centerville, Indiana was one of thousands that decided to head west for gold in 1850. Aged forty-five, a wagonmaker and owner of

143 David Price, "What is Overgrazing," Beef Magazine, May 1, 1999. http://www.beefmagazine.com/mag/beef_overgrazing.

144 Gazette, June 16, 1852.

145 Gazette, April 25, 1852.

146 John Clark, August 19, 1852. 
his own shop, Lantz was one of the leading citizens of his town. Yet he felt the pull of California. He arrived in St. Joseph on April 17 by ferry and set up camp in the countryside where they traded their mules for oxen but were unable to break camp until May 6. They crossed the Missouri near Fort Kearny at a place called Bowman's Ferry. James A. Seaton, who was a part of the party, wrote in his diary on May 29: "At this point the St. Jo, Independence and other roads come together. The road was perfectly filled with wagons as far as the eye could reach and grass was very scarce.” They then moved north toward Cedar Bluffs. ${ }^{147}$ Around Fort Kearny, there was not enough wood so they used weeds for the fire. After crossing the North Platte via ferry on June 21, much of the livestock were poisoned by alkali grass. Henry Starr wrote in his diary that the cattle and horses "were nearly all of them vomiting and showing every symptom of being poisoned but we effect a cure in every case by drenching them with Lard and Vinegar but it weakened them down very Much." ${ }^{\prime 18}$ On Independence Day they celebrated with Yankee Doodle on the flute and a 100-gun salute. The party soon ended. In the coming days several men came down with the "bloody flux," a colorful description probably of dysentery. One of their prized ponies drowned. Soon Daniel Lantz was dead as well. Most of the Indiana parties that arrived in California did very little mining and almost immediately returned home, their health and their pockets left wanting.

It would be a mistake, however, to overemphasize the amount of death on the trails. Nineteenth-century America in general was deadly. During the same year as the

${ }^{147}$ Randy Brown, "Daniel Lantz and the Wayne County Companies of 1850," Overland Journal vol 9, no3 fall 1991, 1-5.

${ }^{148}$ Brown, "Daniel Lantz and the Wayne County Companies of 1850," 6. 
gold rush in 1849 , over five thousand people died of cholera in New York City. ${ }^{149}$ Four of its public schools were forced to close down, exchanging desks for cots to hold the dying. The city struggled to bury its own dead. Another 2,501 people died in another outbreak in 1854. Additionally, 6,444 died of either typhus/typhoid or smallpox between 1847 and 1854 in the city. ${ }^{150}$ Charles E. Rosenberg wrote in the Cholera Years, "Few towns were sufficiently small or isolated to escape. Madison, Indiana, suffered eight to fifteen deaths a day for several weeks. In Washington, another Indiana town, there were sixty deaths among the few hundred who had not fled. At the height of the epidemic, Belleville, Illinois, had twenty new cases a day. Every store closed; business ceased, and smoke from bonfires lit to purify the air continually shrouded the town. Of three hundred and fifty persons at the camp of the United States Eighth Regiment, Lavacca [Lavaca], Texas, one hundred and fifty died. In [the] Rio Grande valley as a whole, an army surgeon estimated that two thousand out of twenty thousand inhabitants had succumbed. It was calculated that the southern states had lost ten thousand slaves alone, and by September the price of Negros had already risen in response." ${ }^{151}$ Cholera, still the major killer on the trail, was certainly not bound there.

Despite that ever-constant danger, by the 1850 s travel had become increasingly easier to travel according to most diaries on the trail. Historian Joyce Hunsaker, writing about the width of the trails, wrote "The difference between the Oregon Trail of the early

${ }^{149}$ Rosenberg, 108; 112.

${ }^{150}$ Gretchen Condran, "Changing Patterns of Epidemic Disease in New York City," in Hives of Sickness: Public Health and Epidemics in New York City, ed. David Rosner (New Brunswick: Rutgers University Press, 1995), 31.

${ }^{151}$ Rosenberg, 116. 
1840s and the Oregon Trail of the mid-1850s was like the difference between a foot path and a freeway." ${ }^{\prime 152}$ Even the nomenclature shifted during the 1850s to describe the roads themselves. Use of the word "trails" to describe the transportation systems west had given way to "roads." For instance, in Horace Greeley's transcontinental journey he used the word "road" nearly five times more often than "trail." 153 By 1860, there were more than 150 stations of varying quality that marked the trail between Atchison, Kansas and Placerville, California that were used of by the Pony Express. ${ }^{154}$ Of the known drownings between 1840 to 1860 , almost all occurred before 1854. As crossings improved both in practice and knowledge, there are no recorded cases of drowning in 1856 even though sixty thousand emigrants went west that year. ${ }^{155}$ The average travel time to California and Oregon dropped by an average of around fifty days between 1841 and $1860 .{ }^{156}$ Alfred Bowlby and a party of seven other men set out on April 25, 1852 and was able to make the trip to Sacramento, California in only 85 days. ${ }^{157}$ John Unruh wrote that travel during the 1850 s was "described less fearfully, less romantically, and much more objectively."

${ }^{152}$ Hunsaker, 191.

153 This statistic uses both "trail," "trails," "road," and "roads." Furthermore, it controls for proper nouns, such as Santa Fe Trail or Oregon Trail that speak more to its historical name rather than the current condition that Greeley witnessed. Greeley, Overland Journey.

${ }^{154}$ Holmes, ed., Covered Wagon Women: Diaries and Letters from the Western Trails 1840-1890 Vol 8 (Spokane, WA: Arthur H. Clark Company, 1989), 11-12.

155 Rieck, 16.

156 Unruh, 403.

${ }^{157}$ New York Herald,. September 1, 1852. 
Origen Thomson wrote of a "trifling incident" in Nebraska that "caused considerable amusement." He wrote, “A young man going to sleep on guard had his hat stolen, which, according to rule was to be sold at auction." ${ }^{158}$ Later, probably in Idaho, he borrowed a horse and took it to a "Boiling Spring." He continued, "This is a curiosity, indeed, it is near the bank of the river-the water boiling in a basin about ten feet in diameter. The water is impregnated by carbonic acid gas, and will make pretty good soda water by simply sweetening it." ${ }^{59}$ Cecelia Adams wrote about cooking in Oregon, "I baked bread and pumpkin and apple pies cooked beans and meat stewed apples and baked suckeyes in quantitys sufficient to last some time Besides making dutch cheese."160 These more specialty dishes suggest a better way of life on the trail. Ezra Meeker even wrote how the trail helped: "We had fresh milk every day and fresh butter that was churned in the can by the jostling of our wagon. We even had buttermilk. I shall never, as long as I live, forget the shortcakes and cornbread, the puddings and pumpkins pies Wife made on our journey. But above all, I shall remember the luxury of having buttermilk."161

Others took in the beauty of nature. J. R. Bradway wrote, "Clear calm and beautiful Birds singing and all seem cheerful."162 John Clark wrote of a night in Wyoming, "Far south may be seen the icy looking peaks rising one above the other. This was in the evening when the reflection of the setting sun was upon them giving a glow

158 Origen Thomson, May 30, 1852.

159 Origen Thomson, July 20, 1852.

${ }^{160}$ Cecelia Adams, June 27, 1852.

${ }^{161}$ Ezra Meeker, 1852. In Hunsaker, 157.

162 J. R. Bradway May 21, 1853. 
indescribable which imparts to the surrounding country an appearance bordering on the sublime. We sat here sometime in meditation on nature \& her wonderful works. Dark drove us down to camp where we found a good fire \& the slap jacks ready." ${ }^{\prime 63}$ Abigail Jane Scott found "a sight which looks fit for angels to admire. The little hollows which at a short distance from the road we can see almost anytime are generally filled with flowers and varegated with ten thousand tints which are almost sufficient to perfectly enchant the mind of every lover of nature." 164

Others enjoyed the company. Harriet Ward from Utah recorded, "At eve our company all appeared just as social and happy as they would at home, singing their pleasant songs, and Maj. Clarke with his large organ of mirthfulness contributes not a little to their merriment. Mr. White has a splendid campfire near his bower and a happier party one can scarcely imagine than the one then assembled." ${ }^{165}$ Lucy Rutledge Cooke arrived to camp joined by seventy or eighty wagons, writing "indeed the noise seems equal if not exceede any town I've seen of late years. In our men's tent they are playing a violin, banjo \& bones." ${ }^{166}$ Others, like Archer Walters in Nebraska, found improved relations among his company even if forgiveness did not come with it. "That last week there had been less quarreling and those that had robbed the hand carts, or wagons, unless they repent their flesh would rot from their bones and go to Hell."167

\footnotetext{
163 John Clark, July 7, 1852

164 Abigail Jane Scott, May 14, 1852.

${ }^{165}$ Harriet Ward, August 10, 1853.

${ }^{166}$ Lucy Rutledge Cooke, April 1852.

167 Archer Walters, July 24, 1856.
} 
It would be a mistake however to believe that death was completely removed from the trail experience. Indeed, during this period the diaries and letters of migrants contain some of the most heart-wrenching tales and failures. Abigail Jane Scott in 1851 passed seven graves in one day. She spoke of one family from Pennsylvania that lost three people in their company in St. Joseph, yet they pushed ahead "with a wish to overcome evry [sic] obstacle, they determined to push ahead, little knowing that the extent of their ambition would be to come this far on their journey, only to lay the remains of a son in the ocean like and seemingly boundless plains. They have become entirely discouraged and when we left them, they were making preparations to go back." 168 John Clark wrote of a dying man of his company, George Ball of Portsmouth, Ohio, who called for water but his own brother-in-law and old schoolmate did not give him any. At the junction of Independence Road, they met a doctor who said that he could not help. They continued on to the town of Cottonwood where they told Ball that he would die of the measles. Clark recorded, "The tears was full in his eye when he said, I am sorry to leave you \& die on the plain; O my God it is so. Imagine our feelings when the teams were got up \& ready to go. He requested I should go forward \& select the place." Clark went ahead and found a final resting place for the twenty-year-old when the wagon arrived carrying him. He took a drink then "Soon after he said Sister \& Mother then expired. We then wound him in his blanket, the green grass his cooling board until morning" when they buried him. ${ }^{169}$

168 Abigail Jane Scott, May 12, 1851.

169 John Clark, May 12-17, 1852. 
Though danger still presented itself on the trails, it lessoned during the rest of the 1850s despite growing tensions of "Bleeding Kansas" that would lead to the American Civil War. The migrants were prepared and willing to suffer through the trials of the trip in good humor. Ezra Meeker wrote of the disreputable company he met, but the goodness he found as well: "As we traveled, I saw things that would convert the most skeptical to the Presbyterian doctrine of total depravity - actions unbelievably brutal and selfish, to men and women and dumb brutes alike. Yet, there were also many instances of selfsacrifice, helpfulness, and unselfishness. It became a common saying that to know one's neighbors, they must be seen on the plains. I will vouch for that. The trail brought out the best - and worst - in mankind. We were beginning, as they say, to See the Elephant."170 Lucy Rutledge Cooke crossed the Bear River by wading it with five or six in her company. The water up to their waist, they managed to make it with some difficulty. She wrote, "Oh the pleasures of going to see the Elephant!!"171 John Dalton wrote following a bad storm of the previous day, June 2, 1852: "Got up at daylight wet and shivering [but] soon found ourselves ... plodding along in fine spirits, with lighter hearts and strong hopes, determined, like true hearted Yankees, not to be skeared at trials but to brave all difficulties, and yet see the Elephant." ${ }^{" 172}$ Even darker, Joshua Variel, wrote on May 19, 1852, after following the trail now lined with the graves of the earlier pioneers, "I fancy we are on the track of the Elephant."173

\footnotetext{
${ }^{170}$ Hunsaker, 159.

${ }^{171}$ Lucy Rutledge Cooke, May 1, 1852.

172 John Dalton, June 2, 1852.

173 Joshua Variel, May 19, 1852.
} 
Chapter 3 - Enduring the Elephant, 1855-1859

Henry David Thoreau, the great transcendentalist and poet, made his living writing about living in the wilderness and appreciating simple living. An outspoken abolitionist, his writing represented much of the mentality of the hundreds of thousands that crossed the American continent. A keen observer of the homesteading that would occur in Kansas and Nebraska in the mid-1850s, he valued a life of searching for philosophic meaning in the environment. In 1858, he published an article in the Atlantic Monthly,

Strange that so few ever come to the woods to see how the pine lives and grows and spires, lifting its evergreen arms to the light,- to see its perfect success; but most are content to behold it in the shape of many broad boards brought to market, and deem that its true success. But the pine is no more lumber than man is, and to be made into boards and houses is no more its true and highest use than the truest use of a man is to be cut down and made into manure. There is a higher law affecting our relation to pines as well as to men. A pine cut down, a dead pine, is no more a pine than a dead human carcass is a man. Can he who has discovered only some of the values of whalebone and whale oil be said to have discovered the true use of the whale? Can he who slays the elephant for his ivory be said to have "seen the elephant?"174

Thoreau's search for understanding inevitably used the terminology that had been popularized throughout the previous decade. Though most migrants would disagree with Thoreau's critique of business and economic advancement, the West meant opportunity and a chance to slay the elephant.

Bleeding Kansas greatly influenced not only the future of the nation but also emigration and settlement during the decade. Historians discussing the violence between 1855 and 1857 have largely neglected how the previous years of emigration to trailhead towns impacted how the story developed. Some historians have suggested that the

${ }^{174}$ Henry David Thoreau, “Chesuncook,” Atlantic Monthly (June 1858). 
activity of guerrillas and the violence slowed the commercial development in the region. ${ }^{175}$ William Patrick O'Brien writing about Independence claims that the "border warfare between Missouri and Kansas in the 1850s and national Civil War in the 1860s largely destroyed the town's economy and county government." ${ }^{176}$ However, this appears to only have been a fairly minor factor. The total number of migrants passing through the towns was declining from its peak of seventy thousand in 1852 to less than seven thousand in 1855. By then, many of the most adventuresome had already settled in the west. More importantly, large-scale settlement shifted from two thousand miles away to right next door in Kansas and Nebraska. In total, this chapter argues that though the era of border violence disrupted trade occasionally, the border towns themselves showed a remarkable resiliency rather than resignation to the violence and disruption. Burnt buildings and warehouses were rebuilt with surprising efficiency and speed. When steamboats were seized, or migrants robbed, another ship or wagon was not too far on the horizon to continue the push west.

One problem in understanding the period of 1854 to 1857 is that it contains fewer primary sources about life on the trail simply because trail travel was not as newsworthy or novel as in the previous generation. In almost every facet of American life, the number of sources increases during this time, especially with the growth of the mail system and number of newspapers popping up in the antebellum period. Trail diaries and letters actually get increasingly less descriptive approaching the Civil War, especially in the

175 Darrell Garwood, Crossroads of America: The Story of Kansas City (New York: W. W. Norton, 1948), 49.

176 O’Brien, 5. 
Kansas and Missouri border region where hundreds of thousands of people had passed through. Surprisingly, their commentary on border war disruptions was relatively minimal. Kansas and Missouri settlers could not ignore it and neither could the businesses that were supplying their new lives. They would have to endure the elephant.

Starting in 1854, the congressional passage of the Kansas-Nebraska Act meant that concern for many of these jumping off towns became increasingly tied with servicing settlement in Nebraska, Kansas, Iowa, and Missouri. As the eastern edge of the Kansas Territory filled, it attracted settlers from all over. The Missouri Republican, published in St. Louis, noted changed in Kansas Territory, "The country around is filling up with a most enterprising and intelligent people. Thousands have already come in, and thousands are still coming. The lands, for from ten to twenty miles back, have, with but few exceptions, been claimed by squatters... They consist of some of the best stock of Virginia, Kentucky, Tennessee, and Missouri." ${ }^{\prime 177}$ From Weston, a correspondent wrote: "We are all crazy here about Nebraska [i.e. Kansas]. There are four hundred men in town to-day, from Platte County [Missouri], ready to go into the new Territory. I think I can safely say there are over ten thousand people already in this Territory, exploring and making out claims and in less than two months there will be double that number." ${ }^{178}$ It was not just Kansas. The Preemption Act of 1841 was extended in 1854 to encourage migration of Oregon and Washington by giving any head of a family the right to buy 160 acres for $\$ 1.25$ per acre. ${ }^{179}$

${ }^{177}$ Missouri Republican, July 1, 1854.

178 New York Daily Tribune, June 29, 1854.

${ }^{179}$ Rau, 5. 
Historians of Kansas City have long blamed border violence for the drop of trade and migrants, but the city was already experiencing problems. To illustrate that point, a man who identified himself as "Dakota" wrote back east about his trip by steamboat on the Missouri in June 1854. He noted a lack of trade on the Santa Fe in Independence and Kansas City that had seemed to move to Westport. An Ohioan wrote that "Kansas (City) is not a place of much importance," but Westport had "the California trade and outfit business has made it a point of some importance" though "it does not seem to me to have a great prospect." Weston, he surmised, was a city of three thousand inhabitants with a bright future that "is a flourishing place, and does an immense business in the hemp trade." ${ }^{180}$ The increased competition from these other towns benefitted from the enormous amount of travelers in 1850 and 1852 . Weston, and especially Westport, were closer to the Kansas border making them prime locations. Most traffic exiting Kansas City took the road through Westport where they had even more opportunity to buy goods to set up in the territory. Still, the business conducted in Kansas City in 1854 was estimated at $\$ 7,646,463 .{ }^{181}$ Including growth in intercity trade, Kansas City remained a major steamboat port from St. Louis because its spacious landing still allowed for large shipments to be processed.

By the mid-1850s, much of the migration to California and Oregon from the Independence-Kansas City area had shifted north to Council Bluffs and St. Joseph. D. M. Chapman wrote from St. Joseph that "you can scarcely imagine the state of things, not only in this city but all along the frontier line. The rush to California was nothing to it.

180 Barry, 1226.

${ }^{181}$ O’Brien, 157. 
Camps are formed, and tents are dotting all the hills and valleys. Thousands are waiting 'the permit' to cross. Large numbers have organized for mutual protection and defense, and have crossed the river, and are locating claims, and staking out farms." ${ }^{182}$ Another writer named "Philos" wrote of St. Joseph, "This certainly is a very remarkable place. Although the river has washed away its levee, and encroached far upon the town, taking away large warehouses, stores and dwellings, it is going ahead in business, prosperity and enterprise, and increasing in population, as if there had been no such calamity." 183

Much of the changes that affected the development of the border towns were because of national events and political shifts. The violence that would come to the Kansas and Missouri border in many ways came from the basic ideas of democracy. Lewis Cass of Michigan offered the idea of popular sovereignty, or the ability of the people of the territories to decide for themselves on the issue of slavery. This expanded democratic rights for the growing white populations who saw popular sovereignty as a chance for economic advancement. The issue was championed by Stephen Douglas who had designs of building a railroad from Chicago through the Nebraska Territory. The problem was that New Englanders often opposed western expansion, so he opened up the possibility for slavery in the territory to gain enough votes from the south. Not only did this negate the Missouri Compromise of 1820 that disallowed slavery north of the $36^{\circ} 30^{\prime}$ line, but it reignited sectional controversies. Despite those shortcomings, Douglas was able to narrowly get the Kansas Nebraska Act passed in May 1854, leaving the question of slavery up to popular sovereignty in the new territories. This angered many freesoilers

182 June 13, 1854. Barry, 1227.

${ }^{183}$ Barry, 1224. 
who were gaining ground in the north, especially among antislavery Whigs and Democrats. This brought together a coalition such that by 1856 , the Republican Party ran John C. Fremont for President. Their rallying cry of "Free Labor, Free Soil, Free Men" connected these ideas of democracy and emphasized that the alternative was a threat to the American way of life. With the Kansas Territory now up for grabs, proslavery and antislavery advocates called on men and women to venture west to secure America's destiny.

Signed on May 30,1854, the Kansas Nebraska Act dramatically changed the trailhead towns that had greatly profited from overland and trade traffic of the previous years. Popular sovereignty in many ways was a celebration of settler sovereignty. Kansas counted nearly eight hundred white settlers in May 1854 that grew to eight thousand by the first territorial census. ${ }^{184}$ The opening of Kansas and Nebraska also allowed for the growth of ports in towns on the west side of the Missouri River at Atchison and Leavenworth in Kansas, and Nebraska City and Omaha in Nebraska. The growth of these jumping-off places negated the need for a ferry service across the Missouri River. ${ }^{185}$ Missourians in particular were elated by the prospects of popular sovereignty. The Missouri Republican in St. Louis defended popular sovereignty with a classic piece of antebellum rhetoric that equated all its opponents with abolitionism, "Is it true, that a portion of American citizens have been ostracized and denied rights and privileges accorded to others, even foreigners, merely because their opinions and 'property' do not

${ }^{184}$ Nicole Etcheson, Bleeding Kansas: Contested Liberty in the Civil War Era (Lawrence: University Press of Kansas, 2004), 29.

185 Lass, 63. 


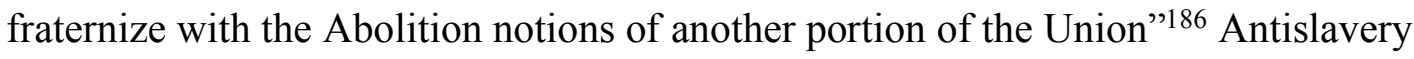
Kansans and many in the North did not agree. William Cullen Bryant of the New York Evening Post wrote, "If this paper was three times its present size, and if it were issued three times a day instead of once, we could not then have space enough to record the action of patriotic meetings through the Northern States protesting against the repeal of the Missouri Compromise by the passage of the Kansas-Nebraska Bill." ${ }^{187}$ The tumult was so great that when Douglas returned to Chicago to defend the act, the crowd did not let him finish his speech. Douglas remarked, "I could travel from Boston to Chicago by the light of my own effigy." 188

The development of pro and antislavery politics is complex, and historians have filled the shelves examining all of the changes through the chaotic 1850s. In effect, the events played out with two competing visions of freedom. The first premised on free labor ideology, that Kansas should be admitted as a free state which would ensure that slavery would not be extended and ensured the nation would be built on republican men, who worked their own land and not for another. The second, proslavery ideology sought the freedom of self-determination. No one could limit the economic or political advantages of the white man. A threat to slavery was a threat to himself and his family and needed to be protected. Furthermore, antebellum arguments had shifted from a

${ }^{186}$ Missouri Republican, February 2, 1854.

${ }^{187}$ Cited in Eli Thayer, A History of the Kansas Crusade--Its Friends and Its Foes (1889; reprint, New York: Books for Libraries, 1971), 13.

${ }^{188}$ Etcheson, 23. Founding father John Jay, after negotiating the infamous Jay's Treaty with the British in 1794, reported a similar response by his countrymen. It is unclear when Americans stopped this awesome practice. 
Jeffersonian notion that slavery was a "necessary evil" that the Union must endure to a "positive good" for not only the nation, but also the slaves themselves. By the 1850s, the majority of arguments for and against slavery had already been made, but the decade would catalogue a series of outrages to bolster each side.

Proslavery ideology had developed a common theme that abolition was an outside influencer seeking to destroy the southern way of life. This was accepted by most as fact by the 1850 s. Missourians generally agreed with this notion but also complemented it with their own history. Most Missourians or their parents were emigrants themselves to the region, creating civilization out of wilderness. They suffered through the early lean years of settlement and therefore earned the right to establish communities in Kansas with their own ideals. "Missouri wagons had left deep scars upon the plains to witness possession by the right of conquest," one observer explained, referring to the Santa Fe trade. "Rightly the Missouri farmer...[viewed Kansas as] his particular domain; it belonged to him as new lands had traditionally belonged to settlers nearest their borders." ${ }^{189}$ Even though the number of abolitionists that came to Kansas at first was relatively small, Missourians tended to view all northern migrants as extremist abolitionist intruders who skipped midwestern settlement and instead benefited from the decades of hard work of Missouri residents and their kin. When one Missourian arrived to a camp, he encountered a Kentuckian and exclaimed, "Too many infernal abolitionists are getting into the country, and for my part, I am for tarring and feathering and gutting and hanging and drowning the scoundrels until not an abolition thief shall be found in

${ }^{189}$ Patrick Trophy, Three Hundred Years--Historical Highlights of Nevada and Vernon County Missouri (Boulder, CO.: Donna G. Logan, 1993), 110. 
Kansas!" ${ }^{190}$ These thieves, he believed, not only led to the loss of slaves, but of land that should go to those who had already civilized the West.

One element often missed by historians is that these ideas of liberty had been one of the principal motivations to move west of the Mississippi to states like Iowa, Missouri, Illinois, Indiana and others during the previous thirty years. The acceptance on both sides that a threat to liberty was a threat on their lives had been nurtured in the migrant philosophy for years. The Missouri Republican wrote that its passage signaled "the old Revolutionary principle that the people of the Great West are capable of self-government, and of managing their domestic affairs with as much and perhaps more skill than our Abolition sympathizers." ${ }^{\text {191 }}$ The lexicon may have shifted, but the central tenets of liberty had already been established. Though historians have focused their story of Bleeding Kansas on outspoken abolitionists and fire-eaters, the majority of migrants came not from New England or South Carolina, but from right next door. Only around four percent of settlers came from New England whereas fifty percent of settlers came from Missouri. About a third came from midwestern or mid-Atlantic states. ${ }^{192}$ Furthermore, Missouri had around 87,000 slaves in the state with 17,000 of them located along the western border in the hemp and tobacco growing regions. ${ }^{193}$ Abolition was not an abstract concept, but a possible practical limit to slave owners' economic futures. Both sides believed that their liberty was threatened by other settlers and by opposing politicians in Washington.

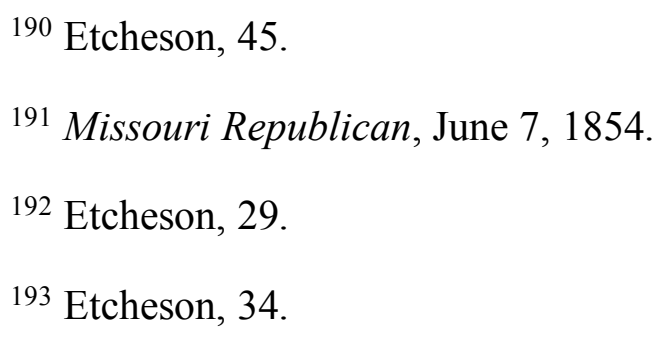


Fearing widespread migration from northern states, Missouri settlers and proslavery advocates expedited the territorial election before the "abolitionists" could gain a foothold. Who could vote though? The answer is that it mattered on a case-by-case basis, often decided by a judge's discretion. This became even more problematic considering antebellum voting procedures denied any secrecy. Ballots were often color coded for candidates, making the judge's decision easier. Even though territorial governor Andrew Reeder announced that residency and continued residency were required to vote, it simply did not occur on the local level. The widespread corruption tainted voting for the territorial legislature. Missourians flooded over state lines and voted for the proslavery delegate J. W. Whitfield. Later, an investigation found that of the 2,258 votes in the election, 1,700 were fraudulent. ${ }^{194}$ In the March 1855 territorial election, fraud was even more rampant. Over six thousand men voted with 5,427 going for the proslavery plank. The territorial census conducted the same month concluded that Kansas had only 2,905 citizens. The Westport Frontier News called out the "Freemen of the South, pioneers of the West" in March 1855. They signaled “...this is the twelfth hour of the night — birds of darkness are on the wing — the day will soon dawn — the battle will soon commence. Arouse and fight a good fight! Let the eagle of victory perch upon your banners. Steady, men! Forward!" 195 Over the next month, Governor Reeder's mail was filled with complaints from election judges who were threatened with violence. When the

194 Etcheson, 34.

195 A. Theodore Brown, Frontier Community: Kansas City to 1870 (Columbia: University of Missouri Press, 1963), 97. 
territorial legislature came into session, Sara Reeder wrote, "We in Kansas already feel the iron heel of the oppressor, making us truly white slaves." ${ }^{.196}$

That July, the first territorial capital of Kansas was set up at Pawnee, near modern day Fort Riley. It lasted four days before proslavery advocates forced it west to the Shawnee Methodist Mission southwest of Kansas City. The freestaters believed the election to be fraudulent, though their complaints fell on deaf ears in Washington. President Franklin Pierce seemed to try and avoid the topic entirely, choosing to leave the issue to the citizens (and non-citizens) of Kansas. Not to be outdone, thirty-seven antislavery delegates met to create a competing legislature in Topeka on October 23, 1855. They, however, were not as united. Though Missourians tended to depict all of them as rabid abolitionists, the convention scuttled when the issue of free black men suffrage arose. The real uniting principle was for self-determination through democracy, a right they believed was taken away earlier that year. The Topeka constitution, as it became known, excluded free black suffrage and banned the practice of slavery. President Peirce saw it as a revolutionary act (which it was) and denied its legitimacy.

Kansas City and its surrounding towns still remained in the proslavery camp and supported the first territorial election. The ideology of the trailhead cities remained proslavery and southern in origin into the Civil War. In fact, Kansas City was a southern town. Thirty-one of the thirty-nine men engaged in "representative business" were from below the Ohio River initially. ${ }^{197}$ On June 3,1854 , just a few days after the passage of the

${ }^{196}$ Etcheson, 65.

${ }^{197}$ Brown, Frontier Community: Kansas City to 1870, 97. This is based on only what could be determined as places of origin. 
Kansas-Nebraska Act, a group of Westport citizens met to commit themselves to the protection of slavery in Kansas. On September 9, 1854, H. Miles Moore wrote in his journal about the migration to the Kansas Territory from Leavenworth, "The people from the East are beginning to crowd into Kansas. Agents of Eastern Companies are now in town." ${ }^{198}$ But more than ideology was in play. Business leaders in Kansas City, upon hearing of proslavery gatherings in Independence and Westport gathered to display their bonafides in late December 1855. They resolved, "That as slaveholders and pro-slavery men, we do not desire to excite animosity between the citizens of Missouri and the settlers of the Territories west of us, but to cultivate friendly relations... and that we invite our pro-slavery friends to settle upon the rich lands of Kansas, as the true policy and the only practicable and legitimate means of controlling her future institutions." ${ }^{199}$ Giving their blessing to Kansas settlement for proslavery agitators, the above statement also reinforced their greatest support to extending commerce. Kansas was open for business and the local business community wanted to be involved in it. By the middle of the 1850s, Kansas City and Westport still remained a primary seller of goods to migrants, but increasingly these towns became more of a wholesaler for the surrounding area towns. Even though migration to Oregon and California cratered between 1855 and 1856, the towns still maintained a strong economic hold on goods flowing to the growing population of Kansas. ${ }^{200}$

\footnotetext{
${ }^{198}$ H. Miles Moore, Journal, June 3, 1854.

199 Brown, Frontier Community: Kansas City to 1870, 105.

${ }^{200}$ Unruh, 86.
} 
With two competing visions for Kansas, however, violence was around the corner. Beginning in the summer 1854, Horace Greeley, along with Eli Thayer and Moses Grinnell, began the Emigrant Aid Company of New York and Connecticut to help send anti-slavery people the Kansas with Sharps rifles. ${ }^{201}$ Like many Americans, they were caught up in the increasing desire to influence events on the Kansas and Missouri border. The "Kansas Legion" was formed in February 1855 as a fraternal order to secure Kansas as a free state and "protect the ballot-box from the LEPROUS TOUCH OF UNPRINCIPLED MEN."202 Rifles flooded into the territory, often funded by easterners. Soon Greeley in the pages of the Tribune, predicted that a civil war was to come in the next four years. ${ }^{203}$ Despite the rising tensions, violence tended to be about land disputes in 1855.

One land dispute, though, had broader consequences. Jacob Branson bought a plot of land at Hickory Point, Kansas on the Santa Fe Trail where Franklin M. Coleman had been squatting. Branson grabbed a gun to move Coleman off his property. Around a year later, Branson's friend, Charles W. Dow, went to the blacksmith and on his return home he ran into to Coleman where they may have argued about the land. Branson at some point picked up a gun and shot Dow in the chest, killing him instantly. ${ }^{204}$ Branson was arrested, but not before the homes of proslavery and antislavery people had been burned

201 The society was mainly a failure. It probably only helped out around two thousand settlers, with a third of them returning home.

202 Etcheson, 76.

203 Tribune, November 25, 1856.

${ }^{204}$ Etcheson, 79. 
by opposing sides. Branson was being escorted when the proslavery sheriff Samuel Jones was stopped by a posse of free state men who freed him and took him to Lawrence, a bastion of abolitionism. In response, Governor Wilson Shannon called out the proslavery militia who formed a blockade on the Wakarusa River, though one freestater was able to sneak a cannon from Kansas City to Lawrence. An estimated two thousand men trickled into Shannon's militia from as far away as St. Joseph, Missouri. When three freestate men later tried to pass through the patrol, they were detained and exchanged gunfire, resulting in the death of Thomas Barber. Though Governor Shannon visited Lawrence and gained a tenuous peace, a Lawrence militia was formed for "self-defense." What became known as the Wakarusa War was not much of a war at all. The leaders on both sides seemed to want peace, even though many men underneath them wanted blood. The more important result was how it was interpreted. The freestaters had stood their ground while two of their own were slain. The proslavery militia came away looking like they had been duped. The next time, they would get their revenge.

Sarah and John Everett moved to the newly opened Kansas territories with their two sons in the spring of 1855 . Abolitionists, they in many ways were what Missourians feared. John's father, Robert Everett, was a Welsh Congregationalist minister that published a Welsh translation of Uncle Tom's Cabin the previous year, while John made a living selling them in New York, Ohio, and Pennsylvania. From Oneida County, New York, the Everetts explicitly moved to Kansas to make sure that it was a free state and wrote letters back home to their family about homesteading in the new territory. When John went to scout for suitable locations, he stayed at the hotel of the Massachusetts Emigrant Aid Society hotel in St. Louis. He found a plot of land at Osawatomie, just 
south of the Santa Fe Trail that passed through Olathe and onto Westport. Their life in homesteading appeared to be fairly typical. Their original claim for land was disputed, so they were forced to find another one in the region after they were the "victims of gross falsehood, misrepresentations and fraud." They eventually set up a house that measured 13.5 feet by 15.5 feet. They suffered from continuous bouts of disease and managed to hold on only because of money sent from their parents and a little bit of good luck. Though they missed eastern life, especially newspapers like Horace Greeley's New York Tribune, they grew some crops in 1855 and managed to stay out of the border unrest that was rampant in the region during the year.

The Everetts saw their mission to Kansas as more than economic opportunity, but as a divine calling that would demonstrate that free soil and free labor would be America's future. John wrote his father in January 1856 to tell him that they were safe and surrounded by fellow freestaters, though news of violence at Lawrence and Lecompton had traveled to Osawatomie. He noted the widespread belief of their Missouri neighbors that the eastern emigrants were "cowardly beggars." The Everetts and their ilk demonstrated that they were "provident, industrious men" that were ready to "stand up and defend their rights." He noted how many of them would "dislike and resent being called abolitionists." Their neighbors, overwhelmingly from the west and south, were against allowing emigration of free blacks or enslaved peoples at all. Indeed, the Everetts were disappointed by the lack of abolitionism. "They have a strong instinct against slavery, do not want it about them, but lack the strong moral sense of its injustice which we feel." ${ }^{205}$ In his next letter, John requested his father send him a copy of Uncle Tom 's

${ }^{205}$ John Everett to Robert Everett, January 25, 1856. 
Cabin so they could lend it to people who "need light here on that subject." ${ }^{" 206}$ In many ways, the Everetts were duped by the larger narrative accepted by both pro and antislavery newspapers that the land was filling with rabid abolitionists and proslavery fire-eaters. What they found in Osawatomie were people with a moderate ideology that came to Kansas for a better life. One neighbor, proudly stated he was "pro-slavery to the core" and "threatened to shoot the first abolitionist that steps into the house." The neighbor knew that the Everetts were abolitionists, though, and did nothing. Sarah wrote that "he is as obliging and good as a neighbor as we want."207

One interesting development in the mid 1850s was how the local pro and antislavery forces defended their actions. With the proslavery territorial capital in Lecompton, they had a government recognized by the federal Union that was supported by both President Pierce and the incoming James Buchanan. Slavery was the law of the land, and those who rejected the practice were in rebellion against the government. The Enterprise out of Kansas City was run by Robert Van Horn, a staunch proslavery advocate like most in the Missouri city. His vitriol included the following screed:

The Real Traitors. It is not generally understood who are the real actors in the late revolutionary movements in Kansas, and while the abolitionists, proper, have had to sustain all the brunt of condemnation they have only played their part, while others equally culpable, but more cowardly and dishonestly, have pulled the wires and urged on the others to acts of outrage and lawlessness, with the expectation of slipping out of the trouble when it came, on the plea that they are not abolitionists. $^{208}$

${ }^{206}$ John Everett to Robert Everett, February 1, 1856.

207 Sarah Everett to Cynthia, August 1, 1856.

208 The Enterprise, December 8, 1855. 
When hearing of the December 1855 Free State Convention, the paper editorialized, "It seems that the revolutionists have run mad in their schemes, and are utterly regardless of even the decencies of sedition. Men generally attempt a show of justification for a resistance to authority, but even this subtifuge is thrown away...." After reprinting the meeting's announcement in the rival Leavenworth Register, it wrote, "Thus it will be seen they openly spit upon the National Government, and trample upon the Kansas and Nebraska Act. Traitors in intent for months, they have now thrown off the mask, and openly take measures to organize a revolutionary government within the boundaries of the Republic, owing no allegiance to any authority but their own, which can only be carried into effect by the expulsion of the United States officers, and in opposition to the military power of the nation." 209

On the abolitionist side, they viewed the territorial government as "bogus," and therefore rejected it. These "revolutionaries" called on the Declaration of Independence as their guide to protect their liberties. William Seward spoke in the Senate and contended that Kanas should recognize the free state constitution and compared President Pierce to George III. ${ }^{210}$ The disruption of the democratic vote infringed on their sovereign rights, and rejection of the constitution was their moral authority.

The irony, of course, is that when the Civil War came, their defenses were forced to flip. The proslavery States Rights argument held that the encroaching federal Union was enforcing an unjust government. At the same time, the antislavery North saw the South as illegal and therefore needed to be stopped. Most would see little problem on

${ }^{209}$ The Enterprise, December 8, 1855.

${ }^{210}$ Etcheson, 97. 
shifting their arguments. Both pro and antislavery arguments malleable enough to justify their positions as they related to the government.

The Kansas City Enterprise, usually throwing fire at its opponents, noted the calm in the winter of 1855 to 1856 . The paper reported that Kansas Territory was quiet and "again bright and cheerful as before." ${ }^{111}$ It attempted to assure its readers that "emigration sought the rich plains of Kansas, in a manner constant with the history of American settlement since the birth of the Government—-there was no disturbance." The discord was in fact "not an issue between the people of the Territory, but a political and sectional issue made by parties outside of the Territory, and forced by unwarrantable means upon its people." ${ }^{12}$ Always the city promoter, the newspaper wrote that the city's "business is in a great degree established, and her trade a certainty. - She is now and for all time must remain the depot for New Mexico, all Southern and Southwestern Kansas, and the country tributary to them. ${ }^{213}$ More likely, violence had decreased during the winter because it was cold. The coming year would be the most violent of "Bleeding Kansas."

Skullduggery and violence were often reported in Kansas City, though it is difficult to find corroborating evidence that the violent events actually took place. Reports were made that Kansas City during the period was unsafe. Advertisements were taken out suggesting that merchandise and "free people" could face violence and theft. Other reports came during 1855-1856 that armed fighters were stopping wagon trains and not allowing them to enter the city. The Kansas City newspapers reported that other

211 The Enterprise, December 15, 1855.

212 The Enterprise, December 22, 1855.

213 The Enterprise, January 19, 1856. 
towns were intentionally trying to drive trade from the city by sending agents up the river to warn steamboats that their freight could be stolen or damaged. Whether true or not, it does appear that some of the trade was moved to other cities for a short period of time. The Kansas City Journal of Commerce estimated a slowdown in trade between 1856 and 1857, probably around two million dollars. ${ }^{214}$ The early Kansas historian Charles Deatherage wrote of the period: "Combining state pride, commercial jealousy, and political hatred of border ruffians, they made every conceivable effort to divert this trade. ${ }^{.215}$ However, there did seem to be a growth in trade to the new settlers in eastern Kansas. The "California Road" also became more heavily trafficked as it moved goods from Westport through Mission overland to the growing abolitionist stronghold in Lawrence. Holding the road became paramount, as both pro and antislavery forces were reported patrolling it in an attempt to control trade.

The early spring 1856 trade through Kansas City actually seems to have been conducted unmolested. Also, since the prime period of migration for settlers occurs in late April and May, the lack of reported violence is surprising. A new hotel was being built, with a courthouse and city hall on the horizon. Stocks from the east were beginning to filter in and the Santa Fe trade looked to be on schedule. ${ }^{216}$ But underneath the positive view, looking back, preparations were being made for war. On February 18, the Kansas Pioneer Association of Jackson County, Missouri was formed to "encourage and assist actual Pro-slavery emigration to the Territory of Kansas, by assisting suitable persons,
214 Deatherage, 465.
215 Deatherage, 466.
216 The Enterprise, February 16, 1856. 
who may need such aid, in removing into and subsisting in the Territory, and guaranteeing to them the means needful to purchase and pay for their land when it shall come into market; and by such other means as may be strictly within the objects of this Association." ${ }^{217}$

Rumors abounded, and trade grew. A letter written by a "hoary-headed political sinner" was "intercepted" by proslavery men that detailed the designs of eastern abolitionists. The letter was published in the newspaper, its authenticity doubtful, was from a freestater that called Missourians "invaders." The good Kansans had all taken a "test oath" to "the high priest of the Emigrant Aid Society." 218 Another letter was found aboard the steamboat Arabia disclosing that a man was in charge of escorting one hundred Sharps rifles and two cannons. Why the letter tipped off the authorities instead of the giant cannons is unclear. However, the munitions were confiscated and taken to Lexington, Missouri. ${ }^{219}$ Other New England emigrants came with rifles and Beecher sermons while proslavery southerners streamed in with so many people that it made the "market buoyant.." ${ }^{220}$ A reported two thousand emigrants arrived in one April week, with twice as many coming from southern states. ${ }^{221}$ The road to Santa Fe through Kansas City, crowded with wagons "is much larger than it has ever been, and the amount of money

${ }^{217}$ The Enterprise, March 1, 1856.

${ }^{218}$ The Enterprise, March 15, 1856.

${ }^{219}$ The Enterprise, March 15, 1856.

${ }^{220}$ The Enterprise, April 19, 1856.

${ }^{221}$ The Enterprise, May 3, 1856. 
expended in outfits, etc., greatly exceeds previous years."222 Though southern sympathizing in general, Kansas City businessmen were willing to sell to all who were coming to settle, trade or even make war.

On May 19, Charles Sumner gave an impassioned speech in Congress on "The Crime Against Kansas.” An offensive speech, even by nineteenth century oratorical standards, Sumner attacked the Lecompton constitution and his fellow congressmen that supported it. Pushing further, he singled out A. P. Butler of South Carolina whom he said had taken a "mistress" who "though polluted in the sight of the world is chaste in his sight - I mean the harlot of slavery." ${ }^{223}$ In response, Congressman Preston Brooks, Butler's nephew, attacked Sumner in the senate chamber with his cane. Reflecting the sectional nature of the times, Sumner was reelected even though he was so injured he could not return for over two years. Brooks resigned but was met with an influx of new canes and secured reelection. The violence of Kansas had now made its way to Washington. A week later, proslavery forces moved on the city of Lawrence to quell the "rebellion" occurring there. Moving into the city, the citizens of Lawrence largely turned over their weapons including one howitzer cannon. The proslavery forces then ransacked the Free State Hotel and tried to blow it up. Unsuccessful, they set it on fire along with the first territorial governor Charles Robinson's house and the newspaper's press. Though property was damaged, the sight was less violent than the national newspapers made it seem in the ensuing weeks. Only one man died, a proslavery fighter who accidently was

${ }^{222}$ The Enterprise, April 26, 1856.

${ }^{223}$ Etcheson, 99. 
crushed by some falling stone. The "Sack of Lawrence" as it became known, reverberated across the territory and country.

The most infamous violence came from a lifelong abolitionist named John Brown, who emigrated to Kansas in 1855 with his family. He was a radical, unlike most that settled Kansas, who often went by the name Captain Brown. Along with his sons, he had seen combat in the Wakarusa War the previous year. Upon hearing that Lawrence had been sacked, he resorted to some of the most bloodthirsty violence of the border war. Brown and his posse first went to the cabin owned by James P. Doyle. They grabbed him and two of his sons and executed them. They continued through the night to the houses of Allen Wilkinson, James Harris, and William Sherman. By the night's end, five had been murdered, their bodies mutilated by knives and swords. None of the victims actually owned any slaves, but they all had connections to the proslavery party. A Mr. Sharkey, of Osawatomie, wrote of the great excitement in the Kansas Territory in gruesome detail. "Mr. Sherman had his head split open and was otherwise mutilated, and then thrown into Pottawattamie creek. Mr. Boyle was called out and stabbed in several places-head split open and cut across the face and his ears both cut off. His two sons were killed at the same time, by being stabbed in several places and cut all to pieces. Mr. Wilkerson was used in the same manner; his head was cut open and body cut in several places. It is one of the most horrible outrages that has been committed in Kansas. There are hard times ahead and we do not know what will come to pass."224 The commissioner of Franklin

${ }^{224}$ Sharkey to Joseph C. Ransom, May 28, 1856. Cited in The Enterprise, May $31,1856$. 
County, where the atrocities took place, called for "troops without delay." 225 Though locally some claimed they knew the perpetrators, it would not be until much later that Brown and his associates would be known.

“Old John Brown” continued the violence on June 2, 1856 when he attacked a proslavery force near the Santa Fe Trail. The Battle of Black Jack and the Battle of Franklin two days later outside of Lawrence signaled the full escalation of violence. The free-state legislature was dispersed by the federal army. The leadership on all sides seemed to have lost control and anarchy reigned. Emigrants still trickled into the territory, many of them heavily armed and organized in companies responding to the national news and calls for support. "The fact that a small army of hired soldiers have been sent from distant States," stated The Enterprise, which "signaled their entrance into the Territory by robbery, murder and house burning, has aroused a feeling that will brook no compromise short of their complete and permanent expulsion — and it will be done."226 Robberies became more common. The Northrup and Chick company was robbed on July 29 by a "band of scoundrels" that used the anarchy to start "robbing, plundering and murdering, in some instances, teamsters, wagons, and travelers, until trade has been almost entirely stopped, and no man's life or property is safe."227

By the summer of 1856, there were reports that the trail through Kansas City had become increasingly sectionalized, as had the nation. There were a few reports of southerners like Senator David Rice Atchison leading a party that turned away

225 The Enterprise, May 31, 1856.

${ }^{226}$ The Enterprise, June 23, 1856.

227 The Enterprise, August 2, 1856. 
northerners attempting to land in Kansas City. Settlers trying to use the steamboats were reportedly fleeced of their weapons and encouraged to move to Illinois rather than Kansas. ${ }^{228}$ An alternate route through southern Iowa became more frequented, perhaps to avoid the violence in Kansas City, by an estimated twenty thousand took this route by 1857. ${ }^{229}$ Andrew Reeder, a freestater and former governor of Kansas, when passing through Kansas City was forced to disguise himself when staying at the American Hotel. ${ }^{230}$ The four and a half story brick building contained a table that could seat sixty. Considered locally as a "hotbed of abolitionism," Kersey Coates wrote that "the parlor floor would be literally covered with beds to accommodate the vast tide that was pouring in from the East. Their lodging-room was insufficient, though numbering some fifty or sixty private chambers, in addition to a long room containing some twenty beds for the accommodation of men." ${ }^{231}$ Occasionally, the hotel was surrounded by guards. The hotel was eventually sold from the abolitionist Eldridges to a proslavery proprietor that helped to ease tensions. ${ }^{232}$ Despite the hotel being extremely busy, others reported turmoil in the city. The St. Louis Reader reported that all the roads were being blockaded, especially around Westport.

By June 1856, the border war was increasingly on the doorstep of the abolitionists John and Sarah Everett of Osawatomie, Kansas. John wrote his father about a group of

${ }^{228}$ Garwood, 40-41.

${ }^{229}$ Brown, Frontier Community: Kansas City to 1870, 103.

${ }^{230}$ Brown, Frontier Community: Kansas City to 1870, 100-101.

${ }^{231}$ Brown, Frontier Community: Kansas City to 1870, 101.

232 Brown, Frontier Community: Kansas City to 1870, 104. 
150 "border ruffians" who had begun pillaging homes and stealing horses in Osawatomie. During the raid, John stated that "They broke open all the trunks, took all the money they could find and all the firearms they could find in the house. They went to all the private houses, and took all their arms. They took all the horses they could find around, about 14 in all." The town was taken by surprise, though John was not. "The soldiers came without our request and went away just in the only time they were at all wanted. They seem to be only efficient when on the side of the Missourians. That is of a piece with the whole machinery of justice. Free state men here are treated just as negroes are at the South. They are a class devoted to oppression and persecution, and when protection is needed that protection is at a point where it is not wanted. This same band of marauders were at Prairie City (called also Palmyra or Hickory Point) the day before.” He complained about inactivity of Washington and northerners who allowed this to occur. "It seems to me if the North at all realized our situation, they would with one voice administer a rebuke to the present infamous administration, who for a short lease on the spoils of office, deliver us over as victims to the marauding Missourians, that would be felt and heeded. Look at it. Our prominent men are captured and imprisoned or driven out of the state, some murdered, others imprisoned without even knowing the crime charged against them, and the worst enemies of the actual settlers are furnished by Gov. Shannon with U. S. arms and munitions of war., ${ }^{233}$ Following the sack of Lawrence and the Pottawattamie Massacre, he wrote, "I was very sorry to see that [President Millard]

${ }^{233}$ John Everett to Robert Everett, June [indecipherable], 1856. 
Fillmore had lent his name to the use of the houseburners, thieves and murderers here. I thought even he had too much sense and humanity left for that.",234

Though the Everetts managed to stay safe throughout the summer, John noted the growing violence. He found that every proslavery man he knew believed the legislature was "Bogus," and "the result of a gigantic and well planned fraud, that the elections were carried by an invading mob from Missouri." 235 He grew more and more disgusted by his Missouri neighbors that were setting up false claims and "stay just long enough to call it a residence; put up a log or a rail pen for a shanty, split out a few oak boards to sleep under, and then pass the time in fishing hunting and lounging about. Many families here live almost entirely out of doors from choice in the Summer particularly Missourians." ${ }^{236}$ Missourians were temporary invaders that at the same time were not creating permanent residences, something that seemed to violate the Everetts to the core. Despite the violence, the Everetts were resolved to stay. After the election of James Buchanan, a blow to the freestaters, John wrote that "we hope God will bring good out of evil.."237 By August, things looked bleak in Kansas City. The Enterprise, ran by the chief commerce cheerleader Robert Van Horn, broke from its usual celebration of the city to reveal its problems. Not only were abolitionists fleeing to Lawrence, but also a number of horse and wagon thieves, tax evaders, and murderers. The roving bands seized cities and controlled the fords on the Wakarusa and shut down trade. "Trade to and from the

${ }^{234}$ John Everett to Robert Everett, June 27, 1856.

235 John Everett to Robert Everett, July 10, 1856.

${ }^{236}$ John Everett to Robert Everett, July 24, 1856

237 John Everett to Robert Everett, November 20, 1856. 
frontier towns of Missouri, which amounts to thousands of dollars weekly is entirely cut off - the Territory is under a state of siege, and all intercourse suspended." ${ }^{.238}$ A man from Independence wrote the newspaper, "Kansas City had a very flourishing business at the commencement of the season, but the sad state of things in the Territory has prostrated trade very much." The steamboats were full of people going into the territory and others fleeing the violence. ${ }^{239}$

While trade had declined, people came in droves. The Courier of Kentucky reported that a group of "determined" men were going to the Kansas Territory to bring stability "either by fighting or engaging in the more peaceful pursuits of agriculture and mechanic arts. ${ }^{.240}$ The Missouri Republican reported that another one hundred reportedly came from Georgia and Alabama with their wives and children. ${ }^{241}$ James Ross Larkin was one of the migrants that traveled through Kansas who noted the effects of the previous year. After arriving to Kansas City on September 23, 1856, he traveled to Westport "notwithstanding very disagreeable rumours of the ruffians or guerilla infesting the country." There he met "a set of miserable drunken creatures, who hang about Westport \& Kansas who certainly merit hanging.” He continued, “Things are so disordered after the Kansas troubles. I felt uneasy about starting on my trip after hearing people talk as they did." Traveling through the Kansas Territory he "passed houses uninhabited on account of the Kansas difficulties, \& some that have been burned. One

${ }^{238}$ The Enterprise, August 23, 1856.

${ }^{239}$ The Enterprise, September 13, 1856.

${ }^{240}$ The Enterprise, September 6, 1856.

${ }^{241}$ The Enterprise, September 6, 1856. 
was burning as we passed ... The country is in an awful condition at present, no one knowing how long his house, goods or stock may be safe from the maurauders." ${ }^{242}$

One must be careful though in equating violence with pro and antislavery agitation. The Kansas Territory and life on the trails were notoriously violent. Trailblazing life did not always attract the best of characters throughout the period. Adolphus Windeler wrote in his diary about an incident where a man named David Brown, a notorious thief, stole money from a man named Harry. They confronted him, assembled a "jury," and condemned him to be hanged. Windeler provided the gruesome detail, "An oak tree close by was chosen for a gibbet, James brought up a rope, noose fixed $\&$ greased, I hove the rope over a limb of the tree, $\&$ at $4 \mathrm{oCl}$. The prisoner led up to execution. He was asked by the sheriff if he had any thing to say. No he said. So the noose was fixed round his neck, a white cloth drawn over his face, \& at the word given by the Sheriff we hoisted him up \& I belayed the ropes end round a stump then he was forked up \& down several times to break his neck ... After having hung $1 / 2$ hour he was put in a coffin \& buried." ${ }^{243}$ Another story recorded by Louise A. K. S. Clappe had a similar ending, concerning two men who were acquitted of theft from their partners. The partners, still suspecting guilt, set up a sting operation and caught the men red-handed. Over six hundred dollars was found, and the offender was convicted after a speedy trial. Hung from a tree, his "life was only crushed out of him, by hauling the writhing body up and down several times in succession.” He body hung for a couple hours when a snowstorm covered the man. Clappe wrote, "As if pitying Nature had tried to hide from

${ }^{242}$ James Ross Larkin, September 23, 1856.

243 Adolphus Windeler, 1851. 
the offended face of heaven, the cruel deed which her mountain children had committed. ${ }^{244}$ Other times, a trial was seen as secondary. John Clark wrote of a man named Dunbar who broke the tongue of the wagon. Its owner became aggravated "so he drew his pistol and shot Dunbar dead. He was tried \& hung on our old waggon at sundown. ${ }^{245}$ Edith A. Lockhart, who was traveling from Clark County, Missouri to California, wrote in her diary that a man had been captured for horse stealing. When he tried to escape he was shot. When they buried him they ominously wrote on his headboard, "all who do likewise, shall so perish." ${ }^{246}$ Keep in mind that future travelers would not know what doing "likewise" would even mean.

Historians examining of Kansas City during the border war era have emphasized the almost indiscriminate violence and anarchical actions of border ruffians that terrorized the city. More recent histories of Missouri guerrilla activity have demonstrated that violence was much more controlled, incisive, and directed. Historian Joseph M. Beilein, Jr. demonstrated how manhood was tied to protection of home and kin that motivated violent action. As homefront turned to battlefield, Beilein concluded that "violence could not be random, nor killing be anonymous." The almost braggadocio quality that accompanied bushwhackers was a point of pride, not because of a psychotic need for blood, but because killing was needed to support their new conception of

${ }^{244}$ Louise A. K. S. Clappe, 1851.

${ }^{245}$ John Clark, June 23, 1852. Six days later, Alpheus Richardson probably arrived at the spot where the men were buried. He wrote, "At noon came up where there had been two men just buried. One was murdered and the other was hung for killing him.” Alpheus Richardson, June 29, 1852.

${ }^{246}$ Emmy E. Werner, Pioneer Children on the Journey West (Boulder: Westview Press, 1995), 153. 
manhood tied to the white man's ability to protect their loved ones against a government that threatened their very way of life. ${ }^{247}$

The disruption of trade appears to have been surprisingly temporary. The recurring cholera outbreaks and the Panic of 1857 pulled funds from the railroad. The violence never fully went away on the border, but by 1857 , some normalcy had returned. Kansas City would remain relatively controlled by the federal forces from 1857 throughout the Civil War, despite being surrounded by generally southern sympathizers. Fort Leavenworth was nearby and had infantry as well as cavalry soldiers that had been stationed there since the early trail days. Indeed, the federal army would set up garrisons in Independence, Westport, Pink Hill (northeast of Blue Springs), Lone Jack (east of Lee's Summit), Stony Point (south of Grain Valley), and Sibley. ${ }^{248}$ By 1857, the trade had increased through Kansas City, with one paper remarking that it resembled a fair overrun with merchandise. The St. Louis Intelligencer wrote that Kansas City "had the largest trade of any city in the world, and the point from which all freight and emigrants disembarked." Though clearly an overstatement, these celebratory words were not common coming from St. Louis. Kansas City had established firm connections, according to the Enterprise, with "Franklin, Lawrence, Lecompton, Tecumseh, Topeka, Douglas, Fort Riley, Ogden, Riley City, Manhattan, Osawatamie, Council City, Council Grove, Hampden, Pawnee, Wabansa, Prairie City, Centralia, Fort Scott, St. Bernard, Cofachique, Paola, Neosho, Richardson, Eu-ja-tah and all other points south of the Kansas river.”

247 Joseph M. Beilein, Jr. Bushwhackers: Guerrilla Warfare, Manhood, and the Household in Civil War Missouri (Kent, OH: Kent State University Press, 2016), 10-11.

${ }^{248}$ Garwood, 48-49. 
Over eleven thousand wagons were loaded, most on the Santa Fe Trail. Merchandise sold was in the neighborhood of $\$ 1,500,000 . .^{249}$

The 1857 emigration to Oregon and California was actually higher than most scholars have realized. Henry Buckingham reported that 12,500 passed through Devil's Gate and that many of the emigrants were settlers coming from Missouri, Iowa, Texas, and Arkansas during the year. One of reasons for the increase, according to Historian Michael Landon, was due to companies that operated on the trail. Around thirty companies operated on the California trail from Missouri alone. Sixty-five others were operated in other states, including nineteen from Arkansas, which suggests that the Cherokee trail operated at a fairly high level. Twenty-six additional companies operated to and from the growing Utah territory. ${ }^{250}$ Even though trail deaths were comparatively small to other years, Helen Carpenter noted the casualness of death on the trail: "The cattle are so accustomed now to seeing their fellows by the way side that they have grown quite indifferent and pass by without more than a casual glance. The same may be observed of the people for the little trails leading to lonely graves are not so well worn as those seen heretofore. ${ }^{.251}$ Despite the attempt by southern transplants to control the movement to the Kanas territory, the movement west continued surprisingly unabated.

${ }^{249}$ The Enterprise, February 14, 1857.

${ }^{250}$ Michael Landon, "A Continuous Line of Stock and Wagons: A Reappraisal of 1857 Overland Travel” Overland Journal (Spring 2011).

${ }^{251}$ Rieck, 13. 
By 1857, around 50,000 settlers, mostly northerners, had moved into the Kansas territory. ${ }^{252}$

One of problems with seeing competition between cities as a zero-sum game is that it negates the importance of indirect finance to the region. In November 1857, the Journal reported that the region saw a million dollars in annuities to local Indian tribes, two million in expenditures by the army, two hundred thousand in mail contracts, and one and a half million dollars in southwestern freight. The estimated five million dollars flowed between these cities and buoyed them all during financial downturns. ${ }^{253}$ Kansas City historian Charles Deatherage writes, using the classic early twentieth century style, "the natural advantages, with the keen insight, and business acumen of our early pioneers, in a manner overcame these obstacles, and the City of Kansas held her own against her many rivals, on both sides of the river." In 1856, the city invested in improving the road from the Blue Mills and Wayne City landing and a better road to Westport. They had already cut back the bluff on the levee, thereby widening and paving the road. The city streets were graded and improved in the city including Second, Third, Fourth, Fifth, Broadway, Wyandotte, Delaware, Main and Market streets, from the river to Fifth Street. Between 1855 to 1860 , Milton Payne estimated internal improvement to roads, sewers, and culverts totaled $\$ 150,000 .^{254}$

Despite the growth, trouble still remained as the competing governments fought for supremacy. Elections tended to bring on more problems. Sarah Everett wrote that she
${ }^{252}$ Garwood, 41.
${ }^{253}$ Brown, Frontier Community: Kansas City to 1870, 148.
${ }^{254}$ Brown, Frontier Community: Kansas City to 1870, 152. 
agreed with the Topeka convention to avoid the election, even though some said they should go to the polls with their guns, saying "Let them form their slave Constitution." She advocated a policy of "masterly inactivity." ${ }^{255}$ Her husband John summarized the state of the Kansas Territory on May 28, 1857 to his father in a letter. "You also ask, if there is any hope for Kansas? Kansas is now governed partly by a military despotism, partly by an outside oligarchy, under the form of the most unlimited democracy. This government is carried on by a party whose national strength consists in their professions of devotion to the broad principle of the sovereignty of the actual settler. This unnatural state of things cannot exist long. What the exact solution will be no one can tell. But the principle of democratic rule or the government of a majority of the people will at last triumph. The glaring inconsistency between the principle and practice of our rulers is becoming too ridiculous and absurd, too annoying and humiliating to last long." Taxes could not be assessed in the region, as any assessor would see it as a "very hazardous experiment." The reach of the territorial government was small. "Any one who will hold any office here under the bogus legislature, is socially ostracized and despised as a traitor to the people. But we think more of crops now than politics." Though the political situation remained heightened, many people were simply going on with their lives. ${ }^{256}$

In September 1857, John Everett ventured to the proslavery Lecompton Constitutional Convention, which he saw as a "bogus affair." Everett noted the growing divide in the slavery party, "There were two parties in the Convention. Ultra proslavery and Conservative proslavery. The former party very decidedly in the majority. The

255 John Everett to Robert Everett, April 2, 1857.

256 John Everett to Robert Everett, May 28, 1857. 
Conservatives are in favor of submitting the Constitution to the people, while the other party are opposed." The convention adjourned until after the election held on December 21. The freestate men, however, "all over the territory are forming military companies, and preparing to defend the polls if invaded. Probably the resolute attitude of the free state men will go far to prevent invasion." The government road to Lawrence was filled with land claims that Everett thought was basically empty only two years previous. The only growing proslavery town in the Kansas Territory was Lecompton, he argued, because it is "built up entirely by the patronage of Uncle Sam." ${ }^{.257}$ By the end of 1857, the situation seemed be turning. Sarah Everett wrote her sister, “'Bleeding Kansas' will free herself from her persecutors now or 'die in the last ditch.' Murder and arson and Tyranny have stalked over this wronged and outraged people till forbearance on the part of their victims is no longer a virtue, but a crime, and now with one mind and heart the people are determined to rise up in their might and break the jaws of the wicked and strike from their midst the foe of oppression — God speed them in their righteous purpose." 258 Indeed, 1858 was a boom period for Kansas City as it rebounded from the violence and cholera outbreaks of years past. The Kansas City Daily Journal assessed the tremendous growth of the city just between May to August of that year. There were 596 new houses or additions built in the city proper or the extension south. Over 13,440 wagons were outfitted carrying 26,160 people and 39,900 animals with freight at 49,976,000 pounds. From the west came 27,000 buffalo robes, 131,000 pounds of hide, 19,000 pounds of pelts, and 40,000 pounds of wool and furs. The population exploded

${ }^{257}$ John Everett to Robert Everett, September 18, 1857

${ }^{258}$ Sarah Everett to Cynthia, Dec. 14, 1857. 
from the cholera ridden year of 1855 of 478 to 3,224 in 1857 and 7,180 in 1859.259

During the same years the taxable assessments went from $\$ 54,000$ to $\$ 3,311,730$.

\begin{tabular}{|l|r|r|r|r|}
\hline & \multicolumn{1}{|c|}{$\mathbf{1 8 5 4}$} & \multicolumn{1}{|c|}{$\mathbf{1 8 5 8}$} & \multicolumn{1}{|c|}{$\mathbf{1 8 5 9}$} & \multicolumn{1}{|c|}{$\mathbf{1 8 6 0}$} \\
\hline Merchandise & $\$ 3,185,502$ & $\$ 3,232,321$ & $\$ 2,488,001$ & $\$ 4,273,835$ \\
\hline Warehousing & $\$ 545,000$ & $\$ 116,983$ & $\$ 2,675,930$ & $\$ 164,600$ \\
\hline Live Stock & $\$ 2,148,200$ & $\$ 2,241,217$ & $\$ 110,099$ & $\$ 455,675$ \\
\hline Brick, No. & $\$ 84,578$ & $\$ 96,000$ & $\$ 6,000,000$ & $\$ 5,000,000$ \\
\hline Exports & $\$ 1,767,761$ & $\$ 2,018,045$ & & $\$ 286,891$ \\
\hline Building & & & $\$ 346,770$ & $\$ 191,896$ \\
\hline Manufactures & & & $\$ 130,000$ & $\$ 147,140$ \\
\hline
\end{tabular}

The Daily Journal's editor did not include the violent years between 1855-1857, no doubt intentionally to explain Kansas City's importance. ${ }^{260}$ Yet there were serious moves made during that period to improve the conditions of the city. The first chamber of commerce was formed in 1856 and some of the early meetings that would lead to the railroad that came later. In December 1855, the Missouri legislature incorporated the Kansas City, Hannibal and St. Joseph Railroad Company to build a road near St. Joseph. A street contractor named Michael Smith "straightened the river end of the road into Market street, and under one of the corn-field engineers, of whom we have had such bright examples, had commenced excavating at the bottom of the ravine on Main street." ${ }^{261}$

Regional growth continued. Richard Thomas Ackley and three friends decided on June 21, 1858 to leave Fremont County, Iowa "across the plains to some point we did not know exactly where." They crossed the river with great difficulty at Nebraska City where

${ }^{259}$ The United States census, shown below, put the number at 4,418.

${ }^{260}$ Deatherage, 467-468.

${ }^{261}$ Deatherage, 484. 
in the same year the company Russell, Majors, and Waddell used 800-1,000 wagons and 1,500 men to set up a depot. ${ }^{262}$ One family from Van Buren County Iowa set out for California. They departed about May 1, 1858 from Westport, Missouri through Atchison, Topeka, and all the way to the Colorado where they were reportedly attacked by a band of Mohave and Hualipai Indians. ${ }^{263}$ In 1858 , the S. M. Hays and Company of Council Grove recorded 9,608 tons of merchandise with a capital investment of two million dollars. ${ }^{264}$ Even after much of the trade went to Kansas City or St. Joseph, Independence still benefited as the county seat acting in an administrative role. ${ }^{265}$ Santa Fe trade also increased. Historian Wyman estimated that international trade with Mexico via the Santa Fe Trail topped $\$ 3.5$ million in $1858 .^{266}$

Furthermore, service on the Butterfield overland stage began operating in September 1858. Beginning in Tipton, Missouri it ran 2,700 miles to San Francisco. Built for speed, coaches would switch out horses and travel day and night, bringing the travel time down to around an incredible twenty-three days. Contracted by the government to move large amounts of mail across the continent, a wagon could also hold up to six passengers, with each ticket costing around $\$ 150$. This line would remain in operation

262 Richard Thomas Ackley, “Across the Plains in 1858," Utah Historical Quarterly 9, no 33-4, 1941, 190; Lass, 46.

263 Eugene Bandel, Fronteir Life in the Army, 1854-1861 (Philadelphia: Porcupine Press, 1932), 57.

264 O’Brien, 72.

265 O’Brien, 56.

266 Walker Wyman, "Freighting: A Big Business on the Santa Fe Trail." Kansas Historical Quarterly 1, no. 1 (November 1931), 20-27. 
until the outbreak of the Civil War in 1861 when the contract was transferred to the Union based mail system. ${ }^{267}$

Passage west only intensified with the discovery of gold in Pike's Peak in Colorado during the summer of 1858. Like the California gold rush a decade previous, the discovery was almost immediately overblown and embellished, yet met with the same fervor as word of gold in California spread up and down the Mississippi. Even better, the mines were not all the way in California but merely weeks, instead of months away from the Missouri River. The Oregon and Santa Fe trails had already beaten a quality road into the Colorado wilderness for most of the way. Some even set off without wagons, using handcarts that were pushed by gold seekers without the aid of beasts of burden.

The migration to Colorado began in earnest in spring 1859 as the "Pike's Peakers," as they became known, were part of a national sensation. The Missouri Republican reported, "Who come? The Pike's Peakers and gold seekers-fortune hunters. Every boat from the Ohio is crowded with them, and every boat for the Missouri goes up jammed with people. Boats now loading... at Pittsburgh and Cincinnati are thronged with emigrants... They are coming down the Mississippi and Illinois too- the Pike's Peakers - all with strong limbs and brave hearts, capable of standing the exposures of the prairie wilderness and mountains." 268 Certainly, many of the migrants underestimated the challenges that lay ahead. The newspaper reported "Yesterday I saw

267 Phil Brigandi, “The Southern Emigrant Trail," Overland Journal 28, no. 3 (Fall 2010), 112; Gerald T. Ahnert, "Identifying Butterfield's Overland Mail Company Stages of the Southern Trail, 1858-1861" Overland Journal 32, no. 4 (Winter 2014), 146162.

${ }^{268}$ Missouri Republican, March 25, 1859. In Richard Gehling and Mary Ann Gehling, “Pike’s Peak or Bust, Overland Journal 5, no. 1 (Winter 1987), 5. 
some men starting out with their mining shovels over their shoulders and their diminutive carpet bags on the end of them. There were not five days' provisions in the whole party. One party of sixteen or twenty started with one old horse, and fifty pounds of hard bread. Their intention was to kill game on the road and to sleep in barns at night. They appeared to think that the prairies were covered with barns and sheds, built by the Indians to shelter the buffalo." 269

The major lessons of the California gold rush had been lost to many, but the fortune seeking, risk taking pioneer spirit remained. This brought great excitement to the border towns. Albert D. Richardson wrote in a letter about the incredible number of handcarts and wheelbarrows in the town of St. Joseph. He recounted an event that occurred on the excited streets:

In St. Joseph, a few days since, a train of six hand-carts, with the emigrants harnessed in, had just started for the ferry, and attracted considerable attention, when a fellow of most solemn visage shouted out to them at the distance of half a square: 'Halloa! Hold on there.' The goldseekers stopped while he came up and asked: 'Are you going to Pike's Peak?' 'Yes,' was the rather crusty response. 'Well, why don't you wait for the grass?' continued the interrogator. 'Grass!' ejaculated one of the emigrants impatiently, 'What do we want of grass. We haven't any cattle.' 'Very true; but you are making asses of yourselves, and you ought to look out for provender! ${ }^{270}$

The Pacific Railroad began construction in 1851 and reached from St. Louis to Jefferson

City in 1856. By February 1859 an additional rail service was completed between

Hannibal and St. Joseph. Some people, from places such as Iowa and heading west, began skipping the Kansas City area entirely. James Berry Brown and company, who had

${ }^{269}$ Missouri Republican, March 23, 1859.

${ }^{270}$ Letter from A. D. Richardson in Kansas Boston Daily Journal, April 19, 1859. In Gehling, 10. 
caught the "Pike's Peak Fever," ventured from Iowa to Nebraska City on his way to Fort Kearny in June of that year which had moved from trails to "roads" as the system westward became more spiderlike than a direct route. ${ }^{271}$

Libeus Barney who set out for gold in Colorado called the "Muddy Missouri" the "most winding navigable river known to man." Arriving on April 17, 1859, to the "pretty town, delightfully situated" of Leavenworth where he recognized that the city is "realizing glorious profits out of the general excitement" of the Pike's Peak gold. He described the assembled masses: "Now a party with guns, pistols and picks, their blankets thrown over their shoulders, and with provisions scarcely sufficient to last a week, off they start for the mines, a journey, under the most favorable circumstances, that cannot be performed short of three weeks. Here another party, with hand-carts loaded down with all the necessaries for a comfortable journey—beans, bacon, tea, coffee, sugar, flour, picks, shovels, rockers—-burden enough for a yoke of oxen—and in high spirits they depart. And still again a company of 8 or 10 appear with six yoke of oxen and a monster wagon attached, loaded to excess with the necessaries and a keg or two of luxuries and off they move." ${ }^{272}$

Thomas Cramer, who set out for California in 1859, wrote in his journal about the growing unrest in Kansas City as he quickly passed through. He remarked that there was a small crowd gathered to listen to an "abolition speech from the late distinghished [sic],

271 James Berry Brown, Journal of a Journey Across the Plains in 1859 (The Book Club of California: San Francisco, 1970).

${ }^{272}$ Lebeus Barney, May 11, 1859. In Letters of the Pike's Peak Gold Rush or Early Day Letters From Auraria (San Jose, CA: The Talisman Press, 1959), 18-19. He would sign his letter to the Bennington Banner in Vermont, "One of the Dupes." 
but now infamous" Frederick Perry Stanton, territorial governor of Kansas. Cramer, a southern sympathizer, quickly passed through and found "kindly" accommodations with some northern transplants. Sectional differences did not seem to get in the way, as the "sweet wife" of the proprietor "subdued even the Alpine heights of my anti-Yankee prejudices." ${ }^{273}$ A letter to Kanas City’s Missouri Republican in March 27, 1859 reported on the movement through the city: "Here they come in every steamboat, hundreds, after hundreds from every place- Hoosiers, Suckers, Corn crackers, Buckeyes, Red-horses, Arabs and Egyptians- some with ox wagons, some with mules, but the greatest number on foot, with their knapsacks and old-fashioned rifles and shotguns... Enthusiastic, merry, with light hearts and a thin pair of breeches, they calculate to accomplish all their fondest hopes. Many have sold out all their homes, all their valuables, to furnish themselves with an outfit for Pike's Peak mines... blindly rush headlong into the wild delusion of glittering sands full of golden eggs." 274

In Westport, one could buy a handcart, ox, and harness for only $\$ 58$. A man named R. S. Osbaris of Illinois announced he would make the trip by wagon pulled only by two Newfoundland dogs and two grey hounds. Another, a Mr. Thomas, designed a "wind wagon" with a sail that could pull the weight of 24 passengers and make the trip in only six days. Perhaps not surprisingly, the ship made it only fifteen miles outside of Westport before breaking down. Other, smaller sailed carts reportedly made it all the way to Denver unscathed.

273 Thomas Cramer, Journal, May 12, 1859.

${ }^{274}$ Missouri Republican, March 27, 1859. Printed in LeRoy R. Hafen and Ann W. Hafen, eds., Reports from Colorado: The Wildman Letters 1859-1865 with other related letters and newspaper reports, 1859 (A. H. Clark Company, 1961). 
Those who made it often met with disappointment. There was almost immediately a food shortage by May and many others turned around when it became clear there was not enough gold to go around. An estimated one hundred fifty thousand ventured to Colorado in 1859, with about two-thirds returning within the year without anything to show for it. The merchants, though, of jumping off towns on the Missouri River continued to line their pockets. ${ }^{275}$

By 1860 , Kansas City was back on its feet. Between 1850 to 1860 , the value of slaughtered livestock increased by $\$ 6,477,343$ and wheat production by $37,277,889$ bushels. ${ }^{276}$ Perhaps the ability of Kansas City to weather the storms was due to the remarkable stability of its business leaders. Around twenty men were prominent between 1838 and $1868 .{ }^{277}$ During the Bleeding Kansas strife, moneyed men from the east still saw investment in Kansas City as a good prospect. Kersey Coates bought a series of lots in Kansas City while Thomas H. Swope bought thirty acres and amassed a small fortune during the 1850s. Charles Kearney moved from Westport in 1856 and opened up his successful Santa Fe trade to the city. Joseph C. Ranson, a grocer, and John W. Reid, a farmer, bought large plots and set up successful real estate developments. ${ }^{278}$ One of the prime reasons for Kansas City holding on during the period was their transition to being a major supplier to 107,000 Kansas settlers that called the state home in 1860 . The census of 1860 reported the population growth of the major trailheads: 4,418, Independence

${ }^{275}$ Gehling, 5-13.

276 O’Brien, 52.

${ }^{277}$ Brown, Frontier Community: Kansas City to 1870, 121.

${ }^{278}$ Brown, Frontier Community: Kansas City to 1870, 123-124. 
3,164, Leavenworth 7,379, Weston 2,921, Atchison 2,611, St. Joseph 8,932, Council

Bluffs 2,011 and Omaha 1,881.279

The New York Herald published a summary of the major cities during 1860 and probably overestimated Kansas City's population. ${ }^{280}$

\begin{tabular}{|l|r|r|r|r|r|r|}
\hline Cities & \multicolumn{1}{|c|}{ Men } & \multicolumn{1}{c|}{ Horses } & \multicolumn{1}{c|}{ Mules } & \multicolumn{1}{c|}{ Oxen } & Wagons & Freight (Wt) \\
\hline Kansas City & 7,084 & 646 & 6,149 & 27,920 & 3,033 & $16,439,134$ \\
\hline Leavenworth & 1,216 & & 206 & 10,952 & 1,003 & $5,656,052$ \\
\hline Atchison & 1,591 & & 472 & 13,640 & 1,280 & $6,097,943$ \\
\hline St. Joseph & 4,900 & & 520 & 3,980 & 418 & $1,672,000$ \\
\hline Nebraska City & 896 & & 113 & 1118 & 912 & $5,946,000$ \\
\hline Omaha & 324 & 377 & 114 & 340 & 276 & \\
\hline Totals & 11,603 & 844 & 7,574 & 67,950 & 6,922 & $36,074,159$ \\
\hline
\end{tabular}

The shuttering of the Western Journal of Commerce in August 1860 allowed for the editor to reflect on Kansas City over the previous five years. He wrote, "Those five years have been devoted to the labors of Kansas City. Nothing that we could do in our judgment to advance her interests, was left undone — nothing that conflicted with her interest was spared. From a hamlet we have seen her rise to city proportions and have witnessed her trade swell from four houses, to occupy whole streets with substantial farms and stores. Blocks have taken the place of bluffs, and streets have supplanted to foot paths along the hill sides. Two railroads now point to our doors and their completion known to months." ${ }^{281}$ Deatherage wrote: "During this period, from 1855 to 1860 , the city moved as one man, or as a corporation in which there was no faction. The business

\footnotetext{
${ }^{279}$ Deatherage, 486.

${ }^{280}$ Deatherage, 471.

281 August 2, 1860.
} 
season was in summer, while in the winter all proposed enterprises were discussed and set in motion. The activating in all directions was continually keyed up to the highest pitch, but there was none more than railroad projects, and in the early spring of 1858 , the activity along these lines again became prominent." 282

When Horace Greeley ventured into Kansas for the first time he was part of the movement west with other fortune seekers on the road to Pike's Peak in 1859. It was a period of peace on the trail and the vestiges of border ruffian violence did little to disrupt the movement west. ${ }^{283}$ But Greeley noted, "Yet there was little or no settlement below Olathe-for the next twenty miles that we traveled there was hardly an improvement to each four square miles of the country in sight. And yet, if the Garden of Eden exceeded this land in beauty or fertility, I pity Adam for having to leave it." ${ }^{284}$ Reflecting on Kansas, he wondered what the three great cities were to be. New York and St. Louis were locks, but he could not decide between Leavenworth and Atchison. ${ }^{285}$ It is not coincidental that both towns lay in the free state of Kansas, as his ideology of free labor likely meant more prosperity than their Missouri counterparts across the river. Indeed, he celebrated many of the actions taken such as those taken by Old John Brown, whom he named as one of the saviors of Osawatomie. He did not know it at the time, but John Brown, after leading an uprising at Harpers Ferry, would be hung and reignite the

282 Deatherage, 575.

${ }^{283} \mathrm{He}$ wrote that the "twin curses of Kansas, now that the border ruffians have stopped ravaging her, are land-speculation... and one horse politicians." Greeley, 36.

284 Greeley, 28.

${ }^{285}$ Greeley, 48. 
sectional tensions. The Civil War was around the corner, and although Kansas City

endured the elephant during the border strife, the new decade would deliver even more difficult challenges. 
Chapter Four - Embracing the Elephant, 1860-1865

Sir Richard Burton, an Englishman, descended on St. Joseph to set out for the Carson Valley in 1860. There he recorded a town of disreputability. He wrote, "I scarcely ever saw a sober driver; as for profanity - the Western equivalent for hard swearing they would make the blush of shame crimson the cheek of the old Isis bargee; and, rare exceptions to the rule of the United States, they are not to be deterred from evil talking even by the dread presence of a "lady." Later and more ominously, he wrote "Landing in Bleeding Kansas - she still bleeds." Though trade and peace had largely returned to the region, the scars of Bleeding Kansas had yet to totally heal. Still, the trails remained. $\mathrm{He}$ hopped aboard a wagon and 'fell at once into 'Emigration Road,' a great thoroughfare, broad and well worn as a European turnpike or a Roman military route, and undoubtedly the best and the longest natural highway in the world." ${ }^{286}$ By the time he reached California and boarded a steamer for home, the nation had elected the Republican Abraham Lincoln and set itself on the path to war.

Two years later at Shiloh, Tennessee, the great American satirist Ambrose Bierce approached the battlefield. He wrote that he heard "a dull distant sound like the heavy breathing of some great animal below the horizon." He and the $9^{\text {th }}$ Indiana regiment were on the move to aid General Ulysses Grant in the deadliest battle in American history to that point. Bierce, though, was excited for what the war might bring. He borrowed the phrase from the overlanders, that he was excited in "seeing the elephant." Surviving the battle, he wrote his parents that it had a "mighty big trunk." The suffering and carnage on

${ }^{286}$ Richard Burton, The Look of the West, 1860: Across the Plains to California (Lincoln: University of Nebraska Press, 1862), 6, 20. 
display shifted the meaning of the phrase for many young men. Captain John B. Myer was nearly at the battle when a bullet knocked his cap of his head. He wrote his father afterward that he did "not want to see the [elephant] ...again." 287 The elephant would have to be endured during the Civil War, and Kansas City stood at its heart.

The geographical advantage that made Kansas City a major port on the Santa Fe and Oregon-California trails also contributed to its problems during the Civil War. Its developed landing and the businesses created and sustained throughout the 1850s had made it an important strategic military position that Union and Confederate forces wanted to control. Its position on the Kansas-Missouri border also meant that proslavery and antislavery agitation was more than just an ideological struggle, but the front lines where avoidance or nonparticipation was a political act unto itself. The nearby Fort Leavenworth always ensured that a Union military presence was near to a Kansas City population that supported proslavery guerrillas in the countryside. Kansas City was an "occupied city" throughout the majority of the war, with the possibility of violence always hovering nearby. The city otherwise suffered, losing half its population during the war to voluntary emigration, forced expulsion, or by sending its boys off to war on both sides. ${ }^{288}$ In many ways, Kansas City was a microcosm of the war consuming the nation. This chapter explores the difficulty of maintaining peace in the divided city by focusing heavily on one of its most important newspapers, the Kansas City Daily Journal

287 Joseph Allan Frank and George A. Reaves, "Seeing the Elephant:" Raw Recruits at the Battle of Shiloh (New York: Greenwood Press, 1989), 1-2.

${ }^{288}$ Brown, Frontier Community: Kansas City to 1870, 178. 
of Commerce, edited by Robert Van Horn. ${ }^{289}$ Van Horn was an itinerant newspaper man, working in Pomeroy and Cincinnati, Ohio, but eventually found his way to Kansas City in 1855. With his last bit of money and with investments from his family, he purchased a newspaper called the Kansas City Enterprise. Appealing to the business leaders of the upstart town, the paper was moderately successful but more importantly brought him to town prominence. In 1857, he became the postmaster of Kansas City and by 1861 the mayor. His major influence was in creating the first daily newspaper in the city, which promoted Kansas City in the region and nation. His paper reads mostly as a series of advertisements aimed at the western traffic. In one standard issue in 1860, one could buy almost anything. At four pages in length, as least two were completely filled with advertisements for forwarding and commission merchants, hotels, rail and road transportation, groceries, liquor, furniture, jewelry, carriages, weapons, medicines, clothing, books, carpet, embroideries, boots, watches, saddles, banks, concerts, hosiery, stationery, lumber, hoop skirts, printing services, doctors, house-keeping services, oxen, property, china, midwifery, offers to join the Pugilistic Boxing Association, and, because it is Missouri, a slave woman and her child. ${ }^{290}$ A proslavery advocate, Van Horn became a major supporter of the Union during the war and even became an Army Major when Confederate forces threatened the city. The paper would go through many names and Van Horn would turn over the editorship during the war, but his standing remained important as he came to support Abraham Lincoln in a prominently southern sympathizing city. In

\footnotetext{
${ }^{289}$ David K. Abeel took over the editorship sometime in 1862, but the paper still supported Van Horn's vision in almost every way.

${ }^{290}$ Daily Kansas City Journal of Commerce, June 15, 1860.
} 
one of the best histories of early Kansas City, A. Theodore Brown wrote of Van Horn and his impact after 1855: "In the following years the most characteristic aspect of early Kansas City, its unquenchable thirst for growth — investment, building, populationcame to be almost completely personified in this one man." ${ }^{291}$ Due to the lack of migrant diaries and letters during the war, Van Horn's newspaper and those of his competitors give a unique insight into the commerce and trail systems during the war. ${ }^{292}$

If the newspapers during the Bleeding Kansas era stirred consternation between St. Joseph, Kansas City, and Fort Leavenworth, the Civil War turned up the temperature to boiling. Historians writing on the period tend to treat reports as fact, yet there is very little reported that can be sufficiently substantiated. In general, the Fort Leavenworth newspapers tended to overplay the disruption of trade in Kansas City while Kansas Citians tended to downplay it. When one paper wrote about violence in a city, especially when they reported a motive for violence, it was almost always countered the next day by a competitor. One of the curious elements of these newspaper wars was the fact that nearly all of them were pro-Union. Despite his proslavery leanings, Van Horn and the ensuing editor David Abeel consistently stood against the Confederacy despite the strong

291 Brown, Frontier Community: Kansas City to 1870, 90.

292 The lack of migrant sources presents a major problem for understanding trail life during the war. Trail diaries for the last decade had been declining in general and newspapers carried fewer stories. This was largely due to the almost routine nature of overland migrations. Fewer took the overland trails through Kansas City and of the existing diaries even fewer go into great detail about trailhead cities. For example, Mary Louisa Black, an interesting and determined woman, wrote a fascinating diary of her journey to Oregon in the spring of 1865 after they had freed their slaves in Missouri. Yet, the crossing through the border towns had become so routine that all her diary says is "May 6, St. Joseph and May 11 Council Bluffs." No other description is given. Cited in Kenneth L. Holmes, ed., Covered Wagon Women: Diaries and Letters from the Western Trails 1840-1890 vol 9 (Spokane, WA: Arthur H. Clark Company, 1989), 59. 
southern sympathy of the city and its surrounds. It becomes clear that in reading the newspapers in the area, that almost every edition contained half-truths or outright lies in order to promote their cities. Still, by comparing newspaper reports with citizen diaries and military records, a picture emerges of a struggling city enduring the effects of war.

In addition to death and destruction detailed in newspapers, another casualty was tact. Of the Enquirer Star newspaper, the Daily Journal wrote that it "can tell more falsehoods on a slighter provocation than any newspaper that has ever fallen under our observation. In fact, it never tells the truth when it can think of a lie to utter" and that all its editorials "bear the ear marks of a jackass." ${ }^{293}$ The Leavenworth Conservative accused the Daily Journal of "Nursing Treason," to which the rival responded, "Our sanctimonious neighbor of the Leavenworth Conservative (what a misnomer !) blurts out in one paragraph the condensed malignity and spleen which might - to make use of a supposition - be expected to blubber forth from the lips of a miscreant who had saved himself from drowning by pushing his fellow from the raft - which had borne them both through the breakers, but for the cupidity and pusilanimity which could not brook the hated presence of a rival." Certainly, many of the readers had no idea what this insult meant. But its creativity was moored to a seething hatred of anyone who might stand in the way of Kansas City's prosperity.

Indeed, most of the trailheads experienced great growth during the late 1850s. The year before the war, things seemed to continue, especially for the Kansas City region. The decades of travel and development made it a prime destination. A man from Baltimore wrote that the railroad through Missouri was without exception as "its solidity,

${ }^{293}$ Daily Western Journal of Commerce, June 29, 1861. 
equipment, management and regularity are such, that little is left to say else about it. There is no road in the country that is better constructed, better ballasted, better regulated, or more safely operated than the Pacific Railroad of Missouri." ${ }^{294}$ The established businesses also meant increased capital to advertise to migrants and the increasing number of the settlers of the region. The Burlington Register of Iowa reported that trade from Leavenworth had dropped simply because they failed to advertise. Kansas City, it noted "is alive to the importance of this trade, and her merchants and business men may be seen constantly traversing this section of the county soliciting patronage." 295 The businessmen bragged that their "harbor" surpassed all other western ports in size and the number of vessels passing through. During their visit, the reporter saw hundreds of “prairie schooners" waiting to outfit. ${ }^{296}$

The city also received an enormous boost with the growth of the wool trade. The growing American population needed clothes and the raw goods were moved through Kansas City on their way to eastern markets. The Daily Journal announced that "Kansas City is the natural market outlet or even market itself, of this new gigantic item in the trade of the Great West." In 1860, 1,200,000 pounds of wool arrived from New Mexico. Kansas City was a perfect trade partner as it connected to the Santa Fe Trail and bragged that it "furnishes them with the cheapest, nearest and best shipping point they can get, and when our two eastern roads are completed, which will be within eighteen months of this time, this city will give them a still cheaper and more advantageous shipping point

\footnotetext{
${ }^{294}$ Pacific, Daily Kansas City Journal of Commerce, June 19, 1860.

295 Daily Kansas City Journal of Commerce, June 29, 1860.

${ }^{296}$ Daily Kansas City Western Journal of Commerce, October 31, 1860.
} 
than any other point possibly can furnish. No rival can take it away or even touch it." Combined with the hide market coming from the west, the city was also growing their manufacturing to turn the wool into textiles. ${ }^{297}$ On August 16 of that year, the largest wagon train of the season left the city carrying goods southwest. Forty-six "prairie schooners" drawn by 460 cattle and reached a mile in length to Fort Union, New Mexico. The government train was joined by wool merchants carrying seventy thousand pounds of wool. "There is not another city in the Union in which can be witnessed such immense caravans of internal commerce as the streets of Kansas City has presented during the whole of the present season. Not for one day alone are these overland trains from the 'great plains' to be seen winding their way to and from our city; but we believe that not a day has passed for the last three months but witnessed the arrival or departure of from five to twenty-five of these huge overland vessels, to or from New Mexico, the mines or some of the Government outposts." ${ }^{298}$ Kansas City was not only connecting the Santa Fe trade to the east, but to the growing populations in the West.

Kansas City was also growing among the regional trade. The Kansas City market sold to people in Independence and Clay county. ${ }^{299}$ When six (yes six) men from Independence visited the Kansas City market it was published in the newspaper. ${ }^{300}$ Wholesale groceries were dispatched to Denver City that were prepared by Chas.

297 “Kansas City and the Wool Trade," Daily Kansas City Journal of Commerce, August 19, 1860; August 15, 1860.

298 "The Largest Train of the Season," Daily Kansas City Journal of Commerce, August 16, 1860.

299 Daily Kansas City Journal of Commerce, August 21, 1860.

300 “Our Trade” Daily Kansas City Journal of Commerce, September 4, 1860. 
Kearney in the Kansas City market. ${ }^{301}$ In October 1860, it was reported that the streets of the city "and business houses gave every indication yesterday, of life and activity in business. The streets were a continual throng all day and we noticed in several of our Dry Goods houses, fashionable purchasers from our neighboring towns of Independence and Westport. Kansas City merchants know how to draw trade and they are practicing it." ${ }^{\prime 302}$

On November 1, 1860, the Daily Journal summarized the trade of that year as the freighting season was closing. "It will also serve to show something of the importance of Kansas City as the legitimate market for this immense and steadily increasing inland commerce." Businesses were booming due to trade to Utah, New Mexico, Colorado and government forts in the West and Southwest. Businesses with government freighting contracts like Irwin and Jackman employed 1,060 teamsters and wagon masters, 10,344 wagons, 837 mules, which transported 5,007,686 pounds of freight goods. Mr. Majors' company employed 530, with 470 wagons, 5,916 oxen and transported 2,532,416 pounds of goods. The W. H. Chick and Company counted 1,392 wagons, 3,743 mules, 10,226 oxen, 1,703 men and transported 7,312,616 pounds of freight. The company of McCarty and Barkley counted 742 wagons, 1,800 mules, 5,100 oxen, and 850 men, which were used to transport a million pounds of freight in the year. The Chas. Kearney company sold and transported 1,845,000 pounds worth of groceries while Wheatly and Thatcher added 540,000 pounds of freight. The J. S. Chick and Company added another 575,000 pounds. In all, the freighting alone numbered 17,153,629 pounds, which did not even include the in-city purchases that were estimated to be 2,960,000 pounds. Taken together,

${ }^{301}$ Daily Kansas City Journal of Commerce, September 12, 1860.

${ }^{302}$ Daily Kansas City Western Journal of Commerce, October 7, 1860. 
the Daily Journal claimed that Kansas City freighting firms hauled more tonnage than of all the boats on the Mississippi, Ohio, and Missouri River. Part reporting and part propaganda machine, the paper bragged that the number of employed was equal to "half as large as the army with which the United States conquered Mexico. Two million invested in the carrying trade." And finally, "We challenge all the towns and so-called cities combined, which claim to be freighting points for the plains, to make a showing equal to this. Let railroad interests make a note of these facts." ${ }^{303}$

Like the rest of the nation, Missouri was caught up in the presidential election in November 1860. Stephen Douglas was not only facing Abraham Lincoln, but also John C. Bell of the Constitutional Unionist Party and John C. Breckinridge of the southern faction of the Democratic Party. The latter was seen as the extreme southern version of Lincoln and carried the majority of the south. While Lincoln carried the popular vote nationwide, in Missouri he was only able to carry St. Louis and Gasconade counties due to the large German populations and the political machine set up by the Republican Frank Blair Jr. Lincoln received zero votes in fifteen Missouri counties and one vote in eight others. Douglas very narrowly won Missouri and Democrats carried most of the state offices. The Douglas Democrat Claiborne Jackson won the governorship, while the more radical Breckinridge backers managed to secure several important seats in the state senate. Jackson's election and subsequent calls for secession and arming of the state militia would have widespread ramifications for Missouri throughout the war. ${ }^{304}$

\footnotetext{
303 "Kansas City and the Trade of the Plains," Daily Kansas City Western Journal of Commerce, November 1, 1860.

304 Donald L. Gilmore, Civil War on the Missouri-Kansas Border (Gretna, LA: Pelican Publishing Company, 2006), 105-110.
} 
In the Kansas City region, the city reflected the nation's divided attitude, but only as far as which Democrat to elect. The Border Star of Westport supported the southern Democrat John Breckenridge. Van Horn chided its rival newspaper, arguing since the paper is "to a great extent devoted to farming interests and particularly in the department of poultry" its support was "because they were nominated in a foul manner."305 Forgetting that nothing denotes a good pun more than italicizing the joke, the town probably agreed and was firmly against Lincoln. Like its proprietor, the Daily Journal was politically Democratic and the majority of its political articles promoted that stance. When Stephen Douglas won the Democratic nomination in June, it ran a campaign advertisement every day until the election along with other Democrats on the state ticket. The largest printing house west of St. Louis ran headlines like "ARE YOU IN FAVOR OF PRESERVING THIS UNION? IF SO, VOTE FOR DOUGLAS!"306 Douglas meant the nation would stay together, while Lincoln meant something worse. The next day it ran “ARE YOU OPPOSED TO BLACK REPUBLICANISM? IF SO, VOTE FOR DOUGLAS AND JOHNSON." ${ }^{307}$ By war's end, the newspaper would be one of the foremost Union allies in a region filled southern sympathizers.

Kansas City, despite the rapid growth next door of northerners across the river, still remained relatively southern in identity into the Civil War. In the election, only 72 votes were cast for the Republican Lincoln. And since these ballots were not done in secret, the names of these voters were posted at the courthouse in Independence. During

\footnotetext{
${ }^{305}$ Daily Kansas City Journal of Commerce, July 18, 1860.

${ }^{306}$ Daily Kansas City Western Journal of Commerce, November 4, 1860.

${ }^{307}$ Daily Kansas City Western Journal of Commerce, November 5, 1860.
} 
the ensuing months, at least one parade was seen on the streets celebrating the secession movement. Secession flags were hung in windows and the rebel flag was displayed prominently in the Independence market square. ${ }^{308}$ Readers to the Daily Journal opened their newspapers to find out that Lincoln had been elected. Doubtless, this disappointed the pro-Douglas periodical, but there was little discussion as they waited for confirmation of the results. In fact, the first mention of war came from an interesting place: "The War Commenced. The insignia of War - the cockade is making its appearance upon the persons of the revolutionists throughout the Cotton States, but in this section of Missouri, the badge of the defenders of the Union is a pair of Ordway's boots or shoes, judging from the rush now being made to this fashionable and popular establishment, we are led to infer that he is selling the finest and best articles of boots and shoes at remarkably low figures. Now is the time, which is being made to get good bargains." ${ }^{309}$ Shameless, yes, but it would demonstrate the policy of the newspaper throughout the rest of the war. Commerce was king and any interruption to it brought the greatest condemnation.

While the nation filled with headlines that threatened the possibility of war, the Daily Journal called for cooler heads following Lincoln's election. They argued that they did not believe secession or war would come. "All admit that so long as the Constitution is maintained in good faith and its provisions enforced, we can all live together under it. When those provisions are disregarded or violated, then all of us are for resistance. But until then, he who would trample upon and spurn that Constitution, and 'precipitate the Cotton States' or any other States, in a revolution, is a traitor, and should be treated as

${ }^{308}$ Garwood, 47-48.

${ }^{309}$ Daily Kansas City Western Journal of Commerce, November 8, 1860. 
such. ${ }^{" 310}$ The newspaper put out articles nearly daily saying that it is treasonous to secede. ${ }^{311}$ They feared what would happen if Missouri seceded, "But even admitting that there would be no war between the sections, how will we stand with the agreeable and profitable business relations suspended between us and our neighbors, as they surely would be. Strip St Louis of her trade with Illinois — strip Kansas City and St. Joseph, and indeed, our Western border of the trade of Kansas." Indeed, they feared being cut off from all major northern cities, and knew that trade with Texas or Arkansas could not replace it. ${ }^{312}$ George Caleb Bingham, the great Missouri artist, wrote from Kansas City in December 1860 about "politics, that everlasting theme upon which, as a people, we become periodically stark mad. Such is preeminently our condition at the present time, and unless reason shall speedily resume her sway, I agree with you, that all the combined efforts of those who retain their sanity will not be sufficient to prevent us from going to the Devil."’13

The sanity would not last. The secession winter filled with rumors while drastic actions were taken in Missouri. In his inaugural address, the newly elected Governor Jackson of Missouri called for the legislature to prepare for secession along with South Carolina and to begin procuring weapons. ${ }^{314}$ The state convention was held in February

${ }^{310}$ Daily Kansas City Western Journal of Commerce, November 9, 1860

${ }^{311}$ Daily Kansas City Western Journal of Commerce, November 10, 11, 1860.

312 Daily Kansas City Western Journal of Commerce, November 17, 1860.

${ }^{313}$ Garwood, 79.

314 The same day, the Daily Journal published an article true to its mission: "EFFECTS OF THE DISSOLUTION - Some of the results of the distracted condition of this Union are plainly visible in this city. We noticed in Kelley's Auction Room a large invoice of boots and Shoes and a large and well selected stock of Ready Made Clothing, which 
and demonstrated overwhelming unhappiness with the North in furthering sectional strife. Yet, few in the convention were ready to take concrete steps toward secession. They preferred to wait, much to the consternation of Jackson and his allies. St. Louis presented a major problem. Its arsenal held around sixty thousand muskets, ninety thousand pounds of powder, 1.5 million ball cartridges, 40 field pieces, and facilities to make machinery and more munitions. While Jackson began making moves to control the city's police force, Captain Nathaniel Lyon was brought in to secure the federal arsenal in the event of secession. Lyon was a radical abolitionist, a trusted Union man who could hold the arsenal from the southern sympathizers of the city.

Across the state in Kansas City, southern sentiment was strong, yet the city remained divided. Two meetings were held in early January, one by the "Workingmen" and another by the "Southern Rights" group that passed resolutions that criticized the federal government, yet still hedged against secession. ${ }^{315}$ One writer maintained his proslavery appeal, "A slaveholder in Jackson county has just the same interest in the institution as the slaveholder of South Carolina, and if the dangers that surround his property in Missouri, are greater than the danger surrounding the same class of property in South Carolina, he is entitled to more sympathy, more consideration, and more cooperation, to preserve, protect and defend it." ${ }^{{ }^{316}}$ Another from Randolph County,

some of our Eastern friends have been compelled to send to this market to be forced off at Auction. The sale commences at 10 o'clock this morning, and as Bob has no particular love for the Yankees, he will not trouble himself to make them bring big prices. Be on hand if you are in need of any of the above named articles." Daily Kansas City Western Journal of Commerce, January 3, 1861.

${ }^{315}$ Daily Kansas City Western Journal of Commerce, January 17, 1861.

${ }^{316}$ Daily Kansas City Western Journal of Commerce, January 24, 1861. 
Missouri, cautioned against secession, "No scheme has ever been devised so fatal to the interest of the slaveholder, as that of converting the border free States into a foreign County, which will be the effect of withdrawing this State from the Union." 317 At a Kansas City meeting in February, business leaders convened to announce that they were to "leave politicians to their plots and their reflections." Trade needed to be protected and fostered, construction projects were waiting to be completed, and a better Express and Mail route should be finished so as to connect with the Colorado gold regions. ${ }^{318}$

By spring, however, the growing Civil War tension was apparent in the region. The Missouri Democrat reported that one of the Kansas City mail trains to California was seized in Texas, which the paper called a "Suicidal Act." ${ }^{319}$ On April 20, 1861, a small group of pro-South militia were able to take over the Liberty arsenal located just north of the Missouri river outside of Kansas City It was only guarded by only two officers. Some fled the city to Leavenworth. The Leavenworth Times, always willing to take a shot at their neighbor, wrote that trade in Kansas City "enjoys a sweet repose, and the classic and sublime spectacle of a city in ruins seems about to present itself in unwholesome shape to our view." ${ }^{, 320}$ In response, Lyon continued to raise Union forces in Clay and Jackson counties and moved on Camp Jackson outside of St. Louis, held by the proslavery forces. This resulted in the Union reclaiming the site, but disastrously, men fired into a crowd

${ }^{317}$ Daily Kansas City Western Journal of Commerce, February 1, 1861.

${ }^{318}$ Daily Kansas City Western Journal of Commerce, February 22, 1861.

319 Daily Kansas City Western Journal of Commerce March 3, 1861.

${ }^{320}$ A. Theodore Brown and Lyle W. Dorsett, K. C.: A History of Kansas City, Missouri (Boulder: Pruett Publishing Company, 1978), 26. 
killing twenty-eight civilians. This attack on civilians caused the proslavery people of Jefferson City to form the Missouri State Guard led by General Sterling Price. The now Unionist Van Horn who had become mayor of Kansas City was forced to make a proclamation about the "recent riotous manifestations in the city." He warned those of those whom were "unlawfully assembling and engaging in disorderly acts," and called for a greater police force whose authority will be "rigidly enforced and exercised." ${ }^{\text {221 }}$ By June, federal forces moved into Kansas City and set up Camp Union, at the corner of Tenth and Central streets. This greatly upset the local population, as thousands of uniformed men now patrolled the city. Over the course of the war many of these military men would abuse their power and harass the citizenry. This caused major problems in the coming years, especially in the form of guerrilla fighters.

But for the majority of the summer, Kansas City stayed secure with only a few reports of robberies. The Daily Journal reported, "People in Kansas and Southern Missouri, who desire to come to Kansas City to trade need fear no interruptions, as the city was never more peaceful, or under more perfect order." ${ }^{\prime 322}$ The rest of the state, however, was not violence free. Lyon's men engaged with the Missouri Guard forces at Jefferson City, Boonville, Carthage, and Neosho. In August, his forces met with the State Guard Infantry at the Battle of Wilson's Creek where Lyon was mortally wounded. In St. Louis, the United States' troops were attacked and five men were killed. ${ }^{323}$ At Pleasant

${ }^{321}$ Van Horn, Proclamation, May 15, 1861. Daily Western Journal of Commerce, May $17,1861$.

322 Daily Western Journal of Commerce, June 19, 1861.

${ }^{323}$ Daily Western Journal of Commerce, June 21, 1861. 
Hill, just outside of Independence, a paymaster was robbed by guerrillas that resulted in reports of ten to thirty dead and $\$ 15,000$ to $\$ 300,000$ stolen. ${ }^{324}$ The truth is probably more on the lower end of both estimates. The same day, reports came in about a man in Wyandotte, Kansas, who was robbed because he was suspected to be an abolitionist, though he was not. ${ }^{325}$ At Harrisonville, the Kansas City Home Guard led by Van Horn was dispatched and managed a minor victory. Caught up in the fray were many innocent people. Federal forces were notorious for accosting, arresting, and robbing citizens whom they suspected of ill will. It became so bad that the newly installed Missouri Governor, Hamilton R. Gamble, used his new position after the Union capture of Jefferson City to reassure its citizens. In his proclamation, he stated that the abuses needed to be stopped:

Every effort will be made to stop the practices on the part of the military which have occasioned so much irritation throughout the State - such as arresting citizens who have neither taken up arms against the Government, nor aided those who are in open hostility to it, and searching private houses without any reasonable ground to suspect the occupants of any improper conduct, and unnecessarily seizing or injuring private property. Such acts must be, and will be, discountenanced, and there is every reason to believe, from a general order recently issued by Lieut. Gen. Scott, and from the known disposition of Major General Fremont, whose command embraces Missouri, that such oppressive conduct on the part of the military will in a short time, be arrested. ${ }^{326}$

Gamble, who is probably more famous for being the chief justice on the Missouri Supreme Court in the Dred Scott case, was never able to fully enforce these actions. The federal army would continue these practices throughout the war.

${ }^{324}$ Daily Western Journal of Commerce, July 13, 1861.

${ }^{325}$ Daily Western Journal of Commerce, July 13, 1861. Interestingly, the Daily Journal made this claim because Colonel Davis was a subscriber to its paper and paid in advance. Neither of which an abolitionist would do.

${ }^{326}$ Daily Journal of Commerce, August 8, 1861. 
Much of the violence was carried out by Kansans crossing into Missouri. Jayhawkers, as they became known, operated in a legal gray area in their connection to federal forces. Captain Charles "Doc" Jennison organized the $7^{\text {th }}$ Kansas Calvary in 1861 and commenced raiding parties on the Missouri border. In June, his men arrived in Kansas City and used the city as a base of operations to raid the countryside. At least once, his men assaulted a federal wagon train and were ordered to return the stolen wagons. The commander of the Department of the Missouri, Henry W. Halleck, criticized Jennison for "cross[ing] the line, [to] rob, steal, plunder, and burn whatever they can lay their hands upon." ${ }^{327}$ Jennison was not deterred and moved his men to Harrisonville to support Van Horn's troops and helped secure a minor victory. In September, his forces moved to Independence where he reportedly took out a list of non-Unionists and rounded them up and looted their property. ${ }^{328}$ Another Jayhawker, James Lane, led forces that did much of the same. Following the attack on Fort Sumter, he mustered Kansas soldiers into what would become the "Lane Brigade" with no sanction from the state of Kansas and a rather informal blessing from President Lincoln. A veteran of the border war in the 1850s, he attacked nonmilitary and military targets alike. Most famously, he led the raid on Osceola, Missouri, that burned the majority of the city to the ground. One historian wrote of Lane and his men's actions:

His troops were no better than an armed and organized banditti, and they had more power for evil than mere robbers and murderers, because their officers were acting under regular commissions from the Government which they used as a means of covering up their crimes. The destruction of Osceola was a case of wanton devastation. In this town about one-third of the people were Unionists and

${ }^{327}$ Christopher Phillips, "Jennison, Charles R." Civil War on the Western Border. Online at http://www.civilwaronthewesternborder.org/encyclopedia/jennison-charles-r.

${ }^{328}$ Gilmore, 139-140. 
many were in the Federal Army. When Lane destroyed and appropriated the property there, he made no distinction between the Unionists and the

Secessionists, but destroyed everything which came into his way. ${ }^{329}$

On his way back to Kansas City, Lane's men managed to secure some prisoners of war that were then executed on the spot. Entering Jackson County, they encountered Solomon Young's farm, a Unionist and grandfather of future President Harry S. Truman. The forces shot around four hundred hogs and forced Young's wife to bake them biscuits "until her hands blistered." Young was away on a wagon train in the west, but his son was tortured by tying a noose around his neck and raised and lowered repeatedly. They set the barn on fire and continued on with the Young family's valuables. Together, Lane and Jennison's irregular warfare unsettled Missouri and its people, resulting in roving bands of guerrilla warriors on both sides of the conflict whose actions grew more atrocious as the war continued. ${ }^{330}$

Though the Missouri State Guard clashed with federal forces throughout the war, the majority of combat was small-scale and included guerrilla fighters known by several appellations. The True Republican and Sentinel of Illinois summarized the contemporary understanding of their names:

Jayhawkers, Red Legs, and Bushwhackers are everyday terms in Kansas and Western Missouri. A Jayhawker is a Unionist who professes to rob, burn out and murder only rebels in arms against the government. A Red Leg is a Jayhawker originally distinguished by the uniform of red leggings. A Red Leg, however, is regarded as more purely an indiscriminate thief and murderer than the Jayhawker or Bushwhacker. A Bushwhacker is a rebel Jayhawker, or a rebel who bands with others for the purpose of preying upon the lives and property of Union citizens. They are all lawless and indiscriminate in their iniquities. Their occupation, unless crushed out speedily, will end in a system of highway robbery exceeding

${ }^{329}$ Wiley Britton, The Civil War on the Border vol. 1 (New Yok: G. P. Putnam's Sons, 1899), 147.

${ }^{330}$ Gilmore, 136-137. 
anything which has existed in any country. It excites the mind, destroys the moral sensibilities, creates a thirst for wild life and adventure which will, on the restoration of peace find gratification in nothing but highway robbery. ${ }^{331}$

These definitions were malleable of course and often applied to people who did not deserve them. "Jayhawking" would actually decline during the war as federal forces gained more official power in the region. The regular military, however, would continue harassing the civilian population, which contributed to the rise of the Missouri bushwhacker that threatened the Kansas City region and its trade.

The most notorious and famous Missouri guerrilla was William Clarke Quantrill. Born in Ohio in 1837, he ventured into Kansas to claim property in 1857 like many others after the Kansas-Nebraska Act. Often missed by historians is Quantrill's familiarity with the western trail system that would prove useful during the Civil War. In 1858 , he joined the army as a herder in an expedition to Utah. There he interacted with many Missourians, some of whom offered him aid later in the war. He joined a group to Pike's Peak in search for gold, but came up empty handed. Life on the trails was a difficult one, but it would serve him in later years. He wrote his mother upon returning to Lawrence, Kansas (a town he would later sack):

I have seen some pretty hard \& scaly times, both from cold weather \& starvation $\&$ the Indians \& I am one of 7 out of a party of 19 who started from Salt Lake city for the Gold Mines of Pikes Peak, which are talked of all over the country... I am now in Lawrence after having spent over $\$ 300$ \& many a day \& night when I expected to be killed or freeze to death $\&$ all that saved my head was I was out hunting away from the camp about a mile and a half $\&$ hearing the firing hurried to camp in time to see the Indians driving off our horses \& my friend lying on the ground apparently dead but still breathing with difficulty. ${ }^{332}$

${ }^{331}$ C. M. Chase, cited in Stephen Z. Starr, Jennison's Jayhawkers: A Civil War Cavalry Regiment and Its Commander (Baton Rouge: Louisiana State University Press, 1873), 214.

${ }^{332}$ Quantrill Papers, Kansas Historical Society. 
Quantrill witnessed, and in some cases participated in, the border war violence during the mid 1850s. He would face similar circumstances throughout the Civil War. Skills that he developed during the period — ability to raid, use the trails, and fight on the move-made him a legend and menace to the towns of Missouri and Kansas during the war. Though much of his Kansas life is shrouded in mystery and buttressed by extravagant claims made years later to explain his actions, his dealings were certainly criminal as he was essentially run out of Lawrence. By 1860 and maybe earlier, he had become radicalized with the southern, proslavery cause.

Winters generally brought some reprieve from conflict as travel became more difficult and many of the Missouri guerrillas went south. By 1862, Kansas City stood occupied and still reeling from the disruptions of the previous year. Still, the Daily Journal attempted to put a positive spin on the situation, "Jayhawking has borne sway in these parts for a long time - indiscriminate thieving and plundering has been carried on by a set of outlaws, whose acts of confiscation have been in utter disregard of all law, and for the benefit of themselves alone. But we hope for better things in the future." ${ }^{\prime 33}$ Many of the town citizens had gone off to war, trade had been disrupted, but some normalcy remained. "With the exception of the constant appearance of the military on our streets, we have scarcely been able to realize that our country was plunged in civil war." ${ }^{\prime 34}$ The

${ }^{333}$ Daily Kansas City Western Journal of Commerce, March 18, 1862.

${ }^{334}$ Daily Kansas City Western Journal of Commerce, March 19, 1862. 
paper reassured its readers and other newspapers, many of which would reprint their articles, that "Truly Kansas City is becoming herself again." 335 It continued,

No Danger. - We are aware that many people in the interior have been prevented, by fear of being robbed by guerrilla parties, from coming to this city to trade. We admit that the unsettled condition of affairs in this county, for a long time, conduced to the reasonable apprehension of many, that it was not safe to come to this city; and we know, as a consequence, that a large trade which had previously been done in this city has been turned for the time being to other points. And we may safely say further, that there is not a neighborhood or town in the interior, heretofore doing business at this place, which would not trade with us again in preference to other points, if the people of such neighborhoods or towns, were satisfied of security in coming here...There are no lawless bands, or guerrilla parties, infesting the roads leading into the city. ${ }^{336}$

To be clear, this was not completely true. Its own columns kept track of Quantrill and his gang. For instance, "At Independence and South and East of there, such desperate men as Quantrel [sic] have brought almost total ruin upon parts of the country." ${ }^{\prime 377}$ Still, since spring was generally the period of greatest trade and migration, the relative peace translated to substantial money moving in the region.

Though the records of many migrants traveling through the region were lost, a few records suggest that a reasonable amount of trade and migration still occurred throughout the war. Augustus Ford Harvey perhaps summarized the best known contemporary trail system when he published an 1862 map entitled Principal Routes to the Gold Region. Hired to survey the cutoff at Nebraska City and Fort Kearny, he outlined the Great Central Route that reportedly had "every stream bridged, no fords, no ferries" on its way to Colorado. He noted hotels, stores, blacksmiths, and other details for

${ }^{335}$ Daily Kansas City Western Journal of Commerce, 28, 1862.

${ }^{336}$ Daily Kansas City Western Journal of Commerce, April 6, 1862.

${ }^{337}$ Daily Kansas City Western Journal of Commerce,, March 19, 1862. 
the pioneers to ease their trip to the west. This signaled the increasing level of knowledge for travelers long before the rail system would come to replace it.

A closer examination of the map reveals, however, the greater threat to the commerce moving through the Kansas City region. A system of trails had sprung up along the banks of the Mississippi River north of where it intersected with the Missouri, long the jumping off point for many pioneers. Trails through southern Iowa had increasingly matured and provided a suitable alternative for northerners. Mary Jane Guill, for example, began her trip from Livingston County, Missouri on May 5, 1860. She and her compatriots crossed the Missouri around Council Bluffs, Iowa, far north of Kansas City. ${ }^{338}$ In May 1862, Captain Medorem Crawford, under orders for the Secretary of War, set off from New York to travel to Walla Walla, Washington to quell Native American violence against the enormous wagon trains traveling to the Pacific Northwest. His company was ordered to form in Omaha but was warned that the supply of wagons and animals necessary for the excursion had already been dried up from earlier migrants that had set out that spring. Despite those purported shortages, however, Crawford was able to procure enough provisions for twelve teams with six mules apiece, weapons, and food for a fifty-person team by scouring St. Joseph and nearby towns. ${ }^{339}$

Trade to Santa Fe Trail also seemed to remain stable, even as it shifted. The historian Ralph P. Bieber wrote, "The route taken from Leavenworth was usually by way of Lawrence and Topeka, striking the off Trail somewhere between the present towns of Burlingame and Wilmington, and thence on to Council Grove. An additional change of

\footnotetext{
${ }^{338}$ Mary Jane Guill, Memoir, 1860.

${ }^{339}$ Report of Captain Medorem Crawford, Overland Journal 3 (Winter 1985): 36.
} 
greater significance came about in 1862, when a road was opened up to the north of the old Trail from Ft. Leavenworth to Ft. Larned by way of Topeka, Junction City, Salina, and Ellsworth. This road, used chiefly by the government for the transportation of troops and military stores before 1867, was destined to supersede the old Trail east of Ft. Larned when the railroad began to move westward."’340

Reports from farther down the Santa Fe Trail demonstrated the trade's continuation. At Council Grove, Kansas, a merchant named George M. Simcock recorded the volume of Santa Fe Road trade passing through his small town in 1862 at 3,000 wagons, 618 horses, 20,182 oxen, 8,046 mules, 98 carriages, 3,072 men, and 15,000 tons of freight. Three of the business houses combined to sell $\$ 22,022.04$ worth of freight. A clerk in the Pioneer Store of Council Grove, William Shamleffer, estimated that during this era his store alone sold $\$ 200,000$ of goods a year. ${ }^{341}$ A store owned by T.S. Huffaker sold $\$ 400,000$ in merchandise during one two-year period in the early 1860 s. Of the total, whiskey sales came in around $\$ 12,000$, but only $\$ 15.40$ worth of Bibles were sold. ${ }^{342}$

By May 1862, bushwhacking returned to western Missouri. The Daily Journal recorded several incidents for the rest of the summer, "Scarcely is our pen dry from recording one outrage before we receive accounts of another. The mail coach was

\footnotetext{
${ }^{340}$ Ralph P. Bieber, "Some Aspects of the Santa Fe Trail 1848-1860 Missouri Historical Review 18, no. 2 (January 1924): 162.

${ }^{341}$ Maloy, Morris County, 46; Council Grove Press, June 15, 1863, quote from Leavenworth Times; James E. Hudson, "Camp Nichols: Oklahoma's Outpost on the Santa Fe Trail," Quote from Daily Missouri Democrat (St. Louis), May 11, 1845, in Wagon Tracks, 14 (November 1999): Sharp, "Home-Coming," 567.

342 The Council Grove merchant William.... Sharp. "Homecoming. " 567; Council Grove Press, September 1, 1860, May 4, 1861; Kanza agent Hiram W. Farnsworth in RUSCIA (1861), 666.
} 
attacked by bushwhackers yesterday morning about nine miles below Independence, on Pleasant Hill road, and two of the guard were killed and two wounded. At last account the guard still held the coach, as a messenger had arrived for reinforcements." ${ }^{\prime 343}$ The problem became so acute that General Henry Halleck outlawed guerrillas under threat of death. Captured enemy combatants who were part of the regular army still had prisoner of war rights, but guerillas that surrendered would be executed. This hardline approach actually made the guerillas less likely to give up their arms and made them less likely to show mercy upon capturing their enemies. Quantrill immediately moved on Independence and Westport. Upon meeting a soldier and civilian at a guard station, they murdered them and threw their bodies off a bridge. Especially as innocents could get caught in the violence, this severe punishment actually created more guerrillas than it stopped.

As the violence escalated in 1862 , the rivalry between Kansas City and Leavenworth became more apparent in newspapers. The Daily Journal called the editor of the Leavenworth Conservative a "detestable knave," who was a "more detestable and diabolical spirit [than] could be imagined." ${ }^{344}$ Both cities accused one another of sending spies to report on their enemies. Others were reportedly dispatched to travel down the river to tell potential customers to avoid the city because of violence. Even worse, they accused one another of using mercenary robbers to attack traders. When one theft occurred to a party coming across the Kansas border to Kansas City, the Daily Journal said this "was done, not for the gain of the money which they robbed - for they are amply

\footnotetext{
${ }^{343}$ Daily Kansas City Western Journal of Commerce, June 12, 1862.

${ }^{344}$ Daily Kansas City Western Journal of Commerce, June 14, 1862.
} 
compensated by interested parties in breaking down the growing trade of this city - but for the purpose of making 'out a case' against us, themselves supplying the evidence by their own act." 345 Later, the newspaper complained of an "Abolition element" that was trying to disrupt the city, but was met by a vigilant government that was turning the people more pro-Union every day. ${ }^{346}$ The competition often focused on which city was going to be the major supplier of eastern and southern Kansas.

Kansas City and Southern Kansas. - It is evident that the people of Leavenworth are getting frightened about the future of their little "me-trap-olis." They begin to observe unmistakable signs of life and vigor in the "dead Lion," or one they had supposed dead, but still liveth. And the discovery fills their souls with mortal terror, or what the future may bring them. They may shake and shiver, and seek to escape, by whatever scheme they may devise - they may pay out their thousands and tens of thousands of dollars to officers in the army, in plots to injure and destroy Kansas City. They may, if they choose, employ men to infest our borders, and plunder now and then a team to frighten people from coming to Kansas City to trade - they may cause our warehouses to be burned, or whatever else they may think advantages to their cause, and they may prosper under it for a time, but they may rest assured that it will not be a permanent prosperity. The reign of terror which they are so happy under, will not last always, and when peace shall once more greet us, then Leavenworth can "look to her laurels." 347

Though the populations of the towns differed on issues of slavery, it must be noted that the leaders of both cities were prominent Union men. A threat to their commerce raised the battle flags.

${ }^{345}$ Daily Kansas City Western Journal of Commerce, May 1, 1862. The next year, the Leavenworth Conservative reported "Kansas City. -The people and press of Kansas City are already beginning to fear the action of the Leavenworth Board of Trade. It seems the citizens of that place are now doing just what they accused our merchants of doing last summer." Daily Kansas City Western Journal of Commerce, January 23, 1863.

${ }^{346}$ Daily Kansas City Western Journal of Commerce, June 26, 1862.

${ }^{347}$ Daily Kansas City Western Journal of Commerce, December 21, 1862. 
Not all was bad in Kansas City. In July 1862, the transcontinental railroad act passed Congress which launched a series of celebrations in the surrounding cities. Part relief and part propaganda to announce to the east that their cities were doing well, cities held money drives for the Sanitary commission. Leavenworth drummed up $\$ 3,000$. In Kansas City, their fair to raise money for the Sanitary commission was publicized for nearly two months and opened at Long's Hall on May 11. Dances, auctions, and celebrations occurred for three days where $\$ 3,500$ was raised and sent to St. Louis. ${ }^{348}$ The Daily Journal reported that "The real business of Kansas City has been larger in amount in most departments during this season that it has for the last two years. In the dry goods, grocery, hardware, boot and shoe, and clothing business, a very decided increase has taken place...Kansas City at the present is not unencouraging."349 Though "not unencouraging" is perhaps the definition of a measured response, the city had reason to be hopeful. The Union military controlled much of St. Louis, which opened up trade coming from the Mississippi River. Further, the "Arkansas Road" to Colorado had improved, connecting Kansas City to the communities created by the Pike's Peak gold rush a few years before. The Santa Fe trade continued as hundreds of Mexican trains came to the city, with only one incident on the trail in $1862 .{ }^{350}$

R. H. Hewitt set off from Dundee, Illinois, on his way to Olympia, Washington, in 1862. Hewitt benefitted from the railroad that ran from nearby Chicago down to Quincy, Illinois. He wrote: "The jaunt across the State was attended by no peculiar circumstance,

\footnotetext{
348 Brown, 193-194.

${ }^{349}$ Daily Kansas City Western Journal of Commerce, June 24, 1862.

${ }^{350}$ Daily Kansas City Western Journal of Commerce, November 25, 1862.
} 
other than what usually occurs to every traveler." ${ }^{351}$ Grabbing a steamboat to Hannibal, Missouri he noted how many of the small towns on the way were "given to secession." An abolitionist, who later published his travel diary, Hewitt recounted how the war had affected the Missouri countryside. Of particular note was the small town of Brookfield, a midway stop on the rail between Hannibal and St. Joseph. Though he spent only 24 hours there, he concocted a dystopian picture, that was obviously embellished by years of abolitionist literature, and penned some of his own. The few dwellings he visited were deserted and he pinned the blight on slavery:

The entire State gives evidence of desolation and ruin; R. R. bridges burned; dwelling-houses deserted, torn to pieces, or consigned to the flames. A spirit of vandalism seems to pervade all who are tinctured with this monstrous doctrine of 'State Rights,' as well as this infernal, black-hearted rebellion. The footprints of rebellion are everywhere visible, and at the present writing the iron rule of Martial Law is thought to be the only means that will save the State from ruin. She danced to the tune of secession, and now she is fearfully paying the cost. Through treacherous demagogues was her best interests betrayed, Judas like, and for less than thirty pieces of silver. The blood of murdered thousands calls loudly for redress. The responsibility for the wrongs done the living and the insults to the tombs of the dead rests heavily on those who plunged her into the whirling vortex of secession. Shameless scoundrels ruled and brought her to the verge of ruin. ${ }^{352}$

Upon his arrival in St. Joseph, he noted how the martial spirit pervaded amid a "foul vapor, which is certain to carry disease and death in its course." He and his compatriots set up at what he called "Camp Disappointment," while his Uncle returned to Dundee to deal with the death of his ten-year-old daughter who had gotten sick on the trip and later died. Despite the primitive camp, when rainstorms hit they were able to find shelter for their animals. By the time they broke camp and head to Omaha, three of the party had

${ }^{351}$ R. H. Hewitt, Notes By the Way. Memoranda of a Journey Across the Plains from Dundee, Ill., to Olympia, W. T. (Olympia: Office of the Washington Standard, 1863), 5.

${ }^{352}$ Hewitt, 6. 
contracted measles. Written as much as an abolitionist tract as a travel log, Hewitt's description of Missouri is one of the few that spoke at length about these problems with an embellished tone.

Long forgotten of Civil War was the Idaho gold rush of 1862-1866. Despite the need for Union soldiers, Lincoln and his generals knew that encouraging migration, especially from Missouri, would have a tremendous impact. The gold and quartz mines could act as an economic stimulus to fund the war. Further, the migration of twenty thousand in 1863 and another forty thousand 1864 would help secure western lands against increasing native American hostility. And perhaps most importantly, it moved southern sympathizing Missourians, some guerrillas or guerrilla supporters, away from supply lines in and around Kansas City. This lowered the tension in key areas of Missouri which allowed for greater control of the state. And even though they joined a similar number of northerners, there was surprisingly little violence despite the political and cultural differences on the trails. J. B. Wright of Iowa wrote about "Many Missourians... some fleeing from the turmoil of strife of the civil war and bushwhacking common in north Missouri; and some influenced by the lure of gold." 353 The military provided protection and helped eased some tension in the region.

As the war entered its third year, the nationwide violence was increasing. While the Confederacy had already instituted a draft in 1862, the Union would follow up with one of their own in 1863. As the size of the militaries increased, the battles became larger affairs resulting in larger body counts. Chancellorsville, Chickamauga, and Gettysburg

${ }^{353}$ Irving Merrill, "The Civil War in the West: The 1864 Trail Season," Overland Trails 9, no 4 (Winter 1991): 15-27. 
lay ahead in the year. In short, both armies got better at killing. Regular armies also started using more total war tactics whereby civilian areas became increasingly part of the battlefield. Destroying supply lines, towns, farms, and roads became acceptable military pursuits. Further, the entire purpose of the war shifted for the North as it became more than a war for the preservation of Union. The Emancipation Proclamation went into effect in 1863, freeing the slaves held in the rebellious states of the South. Missouri at the moment was immune, but increasingly more pressure was put on slave owners in the state to either emancipate or shift their slave labor to support the military. Additionally, enslaved peoples took advantage of the dysfunction during the Civil War to free themselves. By 1863, Missouri had lost around 35 percent of their slave property. ${ }^{354}$ The growth of violence nationally was echoed in the occupied state of Missouri that still existed in a state of guerrilla warfare.

The Missouri bushwhacker problem proved detrimental to the development of Kansas City for many reasons. As discussed in chapter three, bushwhackers saw themselves as rational actors who were protecting their home and kin through violence. With a federal army that was largely seen as a foreign occupier, the military and its supporters threatened their bushwhacker way of life. Since Kansas City relied on trade, the guerillas knew that if they robbed trains, wagons, and riverboats and disrupted communication of the telegraph and mail wagons, it would greatly reduce the Union power in the region. Moreover, they could retreat from head-on engagements and find reprieve in the countryside filled with families willing to aid them in exchange for protection. This made controlling the population impossible for the United States

${ }^{354}$ Gilmore, 149 
military. Since finding and arresting guerrilla fighters was difficult, the military moved to a more expansive program by attacking those that supported the irregular fighters. By burning houses, arresting family members, and stealing property, they too tried to cut the supply line that fed the guerrillas. These search-and-destroy missions ravaged the countryside and the violence increasingly grew more gruesome. A man named Dixon was murdered in January 1863 by bushwhackers. His ears were cut off and he was stabbed and shot several times, "making him a most horrible object to look at. The cannibals of South America are humane, compared to these fiends." ${ }^{" 355}$ This, of course, was an attack on family and friends, which led to more revenge raids and killings perpetuated by the guerrillas. It also probably created more guerrilla fighters, especially when all men of fighting age were supposed to join the Union military. Though both sides accused the other of beginning the attacks, the circle of violence spiraled until each side was committing gross acts of misconduct.

On August 13, 1863, tragedy struck. In order to limit bushwhacker support, some southern sympathizing women were rounded up in Kansas City region and placed in a makeshift jail on Grand Avenue between $14^{\text {th }}$ and $15^{\text {th }}$ streets. Though General Thomas Ewing was told of its shaky foundations the previous day, the poorly maintained building collapsed and killed four young women and maimed many others. Almost immediately, conspiracies abounded that charged Ewing with intentionality. Probably due more to negligence, it killed some family members of the most notorious bushwhackers, which in the conceptions of southern manhood was one of the greatest offenses. This opened up a new wave of violence.

${ }^{355}$ Daily Kansas City Western Journal of Commerce, January 13, 1863. 
The target for guerillas was the hotbed of abolitionism, Lawrence, Kansas. Quantrill had long pushed for an attack deep into Kansas. He hoped that it would ease some of the pressure on the Missouri locals who supported and hid them. Crossing south of Kansas City through the friendlier Cass County, Missouri and up through the town of Gardner, Kansas, he and his forces were able to take the people of Lawrence by surprise. The guerillas carried a list of names of Kansans to kill. Quantrill was reported to say, "Give the Kansas people a taste of what the Missourian has suffered at the hands of the Kansas Jayhawkers... Kill, kill and you will make no mistake." ${ }^{356}$ With bullets in their revolvers and revenge in their hearts, they poured onto Massachusetts Street in downtown Lawrence. The disorganized Kansans were shot down, often at point blank range. They raided the liquor stores, pausing long enough to guzzle down whiskey. With the streets secured, they moved to the Eldridge Hotel, the symbol of abolitionism in the city. They looted and started burning every building in their way. By the time the dust settled, 160190 men and boys had been killed and two hundred thousand dollars of property destroyed.

Perhaps one of the most controversial acts of the Border War Era was General Thomas Ewing's response to the sacking of Lawrence. On August 25, he announced General Order No. 11, a sweeping act that required inhabitants in the counties of Jackson, Cass, and Bates to abandon their homes if they lived more than a mile from a town. Loyalty oaths were administered, allowing some to stay at the Kansas City military post. Others were forced to move after fifteen days. The Daily Journal advised its citizens in the area to obey and stand by the order. "It cannot work much hardship upon truly loyal

${ }^{356}$ Gilmore, 238-240. 
men, for there are now very few such outside of the towns, in the counties of the border; and those who are loyal are already at the mercy of the bushwhackers. At the worst, it can make matters no worse than they are now, and have been for the last two years, while it may do much good. It will, at least, breakup the present rendezvous of these outlaws, and compel them to seek subsistence elsewhere. It cannot permanently injure these counties, for with the return of peace they will be resettled by an intelligent and loyal people."357 George Caleb Bingham, a staunch Unionist, opposed the order and talked about the effects of the order: "It is well known that men were shot down in the very act of obeying the order. ${ }^{" 358}$ By the end of August, two-thirds of the border county population were moved and sixty-four citizens of Kansas City were banished. ${ }^{359}$ The order was ruthless, but Ewing was correct in assessing that the guerrillas needed a sympathetic population to be successful. Unfortunately, this enraged the local population, especially since the soldiers who enforced the law were mostly Kansans bent on revenge. The Lawrence massacre and the consequences of the General Order 11 revealed the depravity to which the people of war were willing to go.

Despite the violence, trade and migration patterns through Kansas City and the other trailheads demonstrated an immense amount of resiliency. Certainly, there was a depression, as many of the able-bodied men were pressed into military service. But for an occupied city surrounded by a population that largely opposed the Union with guerillas patrolling the major roads, the results are surprising. The value of Mexican goods moving

${ }^{357}$ Daily Journal, August 26, 1863.

${ }^{358}$ Garwood, 81.

${ }^{359}$ Brown, 185. 
through Kansas City dropped from a high of $\$ 386,172$ in 1860 to $\$ 205,308$ in 1862 . But by 1863 , most of the trade had returned even as it was forced to split the trade with Leavenworth during the year. ${ }^{360}$ In August, the Daily Journal estimated that the spring trade carried over ten million pounds of freight. ${ }^{361}$ It also assured its Mexican partners by printing a letter in Spanish from General Ewing that assured safe travel as stations at Westport, Cottonwood Springs, and Olathe were helmed by soldiers. ${ }^{362}$ Leavenworth also experienced growing prosperity during the war as it became flush with money every time military salaries were paid. Additionally, around half of its money came from increased trade. The Leavenworth Times reported that the city had "grown and fattened on the woes of the border," and had "turned an honest penny (and many a dishonest one, too) out of the misfortunes" that plagued Kansas City and Jackson County. ${ }^{363}$ Moreover, an estimated twenty thousand migrants went west in 1863 followed by another forty thousand in $1864 .{ }^{364}$ Dr. J. H. Finfrock, a surgeon stationed at Fort Halleck in southern

\footnotetext{
${ }^{360}$ Brown, 180.

${ }^{361}$ Kansas City Daily Journal of Commerce, August 5, 1863.

${ }^{362}$ Kansas City Daily Journal of Commerce, August 14, 1863.

${ }^{363}$ Brown, 191. The historian of the Santa Fe Trail, R. L. Duffus, was less impressed than the contemporaries that talked about the success of Leavenworth. He wrote that during the Civil War, "as a military post well out of reach of rebel raids and influences, was the eastern end of the Trail. But there was so little trade in those grim years that Leavenworth can hardly be classed in importance, for us, with Franklin, Independence or Westport." Duffus, The Santa Fe Trail (New York: Tudor Publishing Co., 1930), 105.

${ }^{364}$ Emmy E. Werner, Pioneer Children on the Journey West (Boulder: Westview Press, 1995), 156.
} 
Wyoming, recorded in his diary that he saw 4,274 wagons, 17,584 emigrants, and over 50,000 animals in 1864 alone. ${ }^{365}$

Garland Jefferson Mahan at age twenty-five set out from Cole County, Missouri, in April 1864. His diary details a fairly easy trip through Missouri, pausing only a few times to remark on the countryside and distances traveled. The highlights of the trip were a story about an Englishman who had never seen a tick and another compatriot that decided to chase a skunk. His trip to Montana however, did not go through Kansas City, but up through Iowa and across Nebraska. No mention is made of the Civil War violence. Instead, he recounted the great excitement of travelers coming from Missouri and reported that 1,600 wagons had crossed the river at Omaha, 700 at St. Joe, 800 at Nebraska City, and 400 at Plattsmouth. All of this happened supposedly in only one week. ${ }^{366}$ Mahan's voyage suggests several things. While the Kansas City and its nearby trailhead cities still maintained traffic, the road system had made it increasingly possible for small towns to become self-sufficient way stations for migrants. Kansas City functioned as a nodal center where eastern goods were shipped in bulk and then distributed to the growing towns on the western border. These small towns then could offer similar goods to travelers making the trip from Westport, which was better connected to the growing eastern Kansas population.

Largely unacknowledged by the competing newspapers, the existence of Fort Leavenworth so closely next door probably prevented Kansas City from crumbling to the

\footnotetext{
${ }^{365}$ Walter Edens, "The Overland Trail Diary of Franklin E. Adams: Upward Bound in 1865" Overland Journal 5, no. 4 (Fall 1987): 9.

${ }^{366}$ Garland Jefferson Hahan, Diary, April 18, 1864-May 22, 1864.
} 
Confederacy during the war. Bushwhacking continued throughout 1864. In September, guerillas hit the Missouri town of Barry and a train traveling through St. Joseph. ${ }^{367}$ By the fall, the pages of the Daily Journal filled with violence and growing apprehension of Sterling Price's Confederate-leaning Missouri State Guard that was moving west through Missouri collecting victories. Mayor Robert Van Horn called for its citizens to arm themselves; "The withdrawal of troops to meet the invasion of the rebel army, leaves us to our own resources for protection against marauding parties and bands of guerrillas. It is also the duty of every citizen to defend himself against the common enemy, and to render to the military authority every assistance in the present emergency." ${ }^{368}$ On October 10 , all of the businesses in town were closed and the citizens drilled. ${ }^{369}$ Soldiers from Fort Leavenworth helped secure the city. At the nearby town of Westport, the forces met. Price had been reinforced by guerrilla fighters in the area, but was still outnumbered around ten thousand to fifteen thousand. By the end of the battle, there were around 1,500 casualties and a decisive Union victory in one of the largest battles west of the Mississippi River. Many of the guerrilla forces that had plagued the Kansas City region for years were forced to follow Price in retreat. This freed Kansas City from the great tension for the rest of the war.

Finn Burnett, late in the war around 1865, found himself in trouble. The Missourian's family owned slaves named Uncle Ike and Aunt Stasia that he claimed "were practically free." When the war broke out he joined the Monticello Grays, a

\footnotetext{
${ }^{367}$ Kansas City Daily Journal of Commerce, September 30, 1864.

${ }^{368}$ Kansas City Daily Journal of Commerce, October 4, 1864.

${ }^{369}$ Kansas City Daily Journal of Commerce, October 11, 1864.
} 
regiment in Lewis County, Missouri. He fought in "a scrape" with German soldiers and lost. But a Colonel "conscripted all of us fellows into the Union Army! Enlisted us right then and there. Well, I wasn't about to turn fire on my own friends and relations by fighting as a Union soldier. No sir!” Deserting as soon as he could, he "just jumped out of the frying pan into the fire, though, for that's when I made up my mind to head West." Traveling up to Council Bluffs, the fugitive followed the Platte River as part of the Powder River Army Expedition. Around Fort Sedgwick, he heard the news that the war was over. He would then fight for Uncle Sam in various Indian wars in the postwar era. ${ }^{370}$ The war was over and peace and prosperity could return.

The military had protected Kansas City throughout the majority of the war, yet a series of governmental treaties during the 1850s and 1860s paved the way for postwar prosperity. In 1854, treaties were signed with the Delaware, Shawnees, Sacs and Foxes, Kaskaskias, and Miamis. In 1855, the Choctaws signed a treaty and the Osages agreed to another in 1859 . The treaties tended to contain provisions for Indian rights, especially transportation rights to the land, that would actually benefit the tribes. Indeed, if followed

${ }^{370}$ F. G. Burnett, "Life of F. G. Burnett: As dictated to his granddaughter, Verna," October, 1926. Since Burnett's story was dictated around sixty years after his trip to Oregon, the story should be seen with skepticism. He claimed that his uncle's clerk was Samuel Clemens, who later changed his name to Mark Twain. He wrote, "That's right, Samuel Clemens. Mr. Mark Twain, himself. Of course, that's before he was famous. I remember him being a rather spare-made man, quick-motioned, and spry. And in those days he was young. History made him out a river pilot, but I never knew him as such. To me, he was just Uncle David's clerk. Imagine my surprise when he went west himself and wrote all those books! Everybody started calling him by the steamboat order, Mark Twain, for that's how he signed his stories. My own life on the river was very similar to his character Huckleberry Finn. Why, I wouldn't be surprised if Twain didn't get part of that story from my own life! After all, Finn is what they called me, short for my baptismal name, Fincelius. And I never had much schooling, just off and on. I wasn't a good scholar. I only wanted to run off and play down by the levee. Doesn't that sound like Huck?" In Hunsaker, Seeing the Elephant, 197-217. 
correctly the various tribes could be connected to transportation hubs to increase trade. This of course did not play out in reality. Payments never seemed to come and abuses were rampant. The Delaware claimed that between 1854 to $1861, \$ 48,750$ of timber and $\$ 32,227$ of property were stolen. This led them to signing another treaty in 1860 (Pottawattamie 1861, Kickapoo 1862, as well) that ceded lands, but instead of cash they were paid in railroad stock that would only improve land prices nearby. The promised railroad was slow in coming but the natural resources were being reaped. The irony of course being they were invested in the very thing that would reduce their power for the rest of the century. ${ }^{371}$

Perhaps nowhere was private and public business more apparent than with the early stages of the railroad into Kansas. Most Americans knew that the railroad would soon push across the continent, and competing cities had been campaigning for years to secure railroad rights. As early as 1853 , Senator Thomas Hart Benton, who had been one of Missouri's biggest boosters, gave speeches in the city of Kansas, Westport, and Independence to outline the rail to the Pacific. ${ }^{372}$ Nearly every issue of Van Horn's newspapers carried news of railroad possibilities. Its boosterism in many ways was to try to make Kansas City as appetizing as possible. Rail to Chicago was the money maker. Cameron Road, the connection to the Hannibal and St. Joseph Railroad, was renewed in 1854 under Kansas City leaders Johnston Lykins, Kersey Coates, and Theodore Case. The elite of Kansas City worried about news that the line would run through

\footnotetext{
${ }^{371}$ H. Craig Miner and William E. Unrau, The End of Indian Kansas: A Study of Cultural Revolution, 1854-1871 (Lawrence: Regents Press of Kansas, 1978), 29-37.

${ }^{372}$ May 6 and 7, 1853. Barry, 1150.
} 
Leavenworth or south of the city. How exactly the rail was secured for Kansas City remains murky, and with the railroad industry it is usually safe to assume shenanigans occurred. James F. Joy, a rich Bostonian and a wealth of railroad experience in Michigan, bought shares in the West Kansas Land Company which was run by Kansas City leaders. Concurrently, Robert Van Horn in Washington was able to sneak in bridge and land-grant proposals into an omnibus bill opening the way for the Burlingame railroad company. ${ }^{373}$ The city connected with Lawrence on December 19, 1864. Of greater importance, connections to the east were secured when the Pacific Railroad reached the city in September 1865 .

The establishment of the railroad was the crowning achievement of a city that managed to survive during the Civil War. Historian A. Theodore Brown wrote of the period: "What must be seen is not simple economic growth but something more complicated: the creation of community —a group of people performing the same actions for the same reasons. ${ }^{" 374}$ The city directory recorded 1,400 names in 1860-61 and 1,100 in 1865-1866. Only 280 appeared on both rolls, demonstrating an immense amount of turnover. However, the main leaders largely remained unchanged. Of the twenty men who formed the chamber of commerce in 1857, twelve remained including Coates, Reid, Kearney, Van Horn, and Case that figured prominently into securing the Hannibal Bridge necessary for the railroad. ${ }^{375}$ Though the population declined in the city, especially after General Order 11, the population returned. By 1870, the population ballooned to over

\footnotetext{
${ }^{373}$ Brown, 207-213.

${ }^{374}$ Brown, 131.

${ }^{375}$ Brown, 199-200.
} 
thirty thousand. The elephant of war had been embraced and now the rest of the circus came to the city. 
Conclusion - Elephant Seized

A largely apocryphal story happened on the road as Horace Greeley hitched a ride with the legendary stagecoach driver Hank Monk. Though Greeley reportedly said "there was not a damned word of truth in the whole story," it became part of the Greeley popular biography. Mark Twain, who prominently features in the history of the American West, cemented its legacy in his 1872 book, Roughing It. On Twain's adventure west, one of his drivers told him a story:

I can tell you a most laughable thing indeed, if you would like to listen to it. Horace Greeley went over this road once. When he was leaving Carson City he told the driver, Hank Monk, that he had an engagement to lecture at Placerville and was very anxious to go through quick. Hank Monk cracked his whip and started off at an awful pace. The coach bounced up and down in such a terrific way that it jolted the buttons all off of Horace's coat, and finally shot his head clean through the roof of the stage, and then he yelled at Hank Monk and begged him to go easier - said he wasn't in as much of a hurry as he was a while ago. But Hank Monk said "keep your seat, Horace, and I'll get you there on time!"- -and you bet you he did, what was left of him.

Twain then met three other people on the road who repeated the story word for word exactly. He estimated that he heard "that deathless incident four hundred and eighty-one or eighty-two times." Then, coming upon a stranger, "a poor wanderer who had lain down to die," Twain supplied him with some food and brandy causing the traveler to emotionally give his thanks. Then stranger said, "I can never be able to repay you for it, I feel that I can at least make one hour of your long journey lighter. I take it you are strangers to this great thorough fare, but I am entirely familiar with it. In this connection I can tell you a most laughable thing indeed, if you would like to listen to it. Horace Greeley__ " Twain stopped him and asked for a story of George Washington instead. 
But, Twain recalled, "In trying to retain the anecdote in his system he strained himself and died in our arms." ${ }^{376}$

The popular history of the pioneers is riddled with heroic notions and actions over the environment and disease. A popular video game of any child in the 1990s was “Oregon Trail." In it, the player names his or her traveling companions and sets off from the town of Independence. Disease and rivers threatened at every opportunity. "You died of dysentery" was a common ending for many, which made naming the travelers people you did not like even more important. And no matter how many animals one shot, one could only carry back two hundred pounds of meat to the wagon. Even though the game is nearly unplayable today, it remains a meme on the internet.

But the history of the trail system, of course, is more complex. The pioneers of the 1830s and 1840s created a transportation system from the wilderness that greatly benefitted the travelers who would make the journey in the $1850 \mathrm{~s}$ and $1860 \mathrm{~s}$. The trail was an organism, ever changing. As the trails turned to roads, many overlanders feared the environment less and less. Indeed, the dangers on the trails were in many ways of their own making. Cholera spread in camps, trees and grass became less abundant, and the possibility of violence from fellow travelers threatened them more than nature's elements. Still, over 300,000 migrants made the trip.

The growth of Kansas City was not without its elephants. St. Joseph, Westport, Leavenworth, Council Bluffs and other trailhead towns were seen as competitors, but the

${ }^{376}$ Twain, Roughing It. Twain sarcastically remarked on the universality of the story, "I have heard that it is in the Talmud. I have seen it in print in nine different foreign languages; I have been told that it is employed in the inquisition in Rome; and I now learn with regret that it is going to be set to music. I do not think that such things are right." 
regional economic system that developed created a market that was able to service the immense number of migrants that took to the trails. Disruptions, whether disease or violence, could be overcome because of dynamic leadership and the American need for economic opportunity that the west offered. Public and private interests overlapped, with the government supplying the money and protection necessary for the development of the trails. Though historians like Richard White would later detail how these elements created the transcontinental railroad, the trail system had already sketched the path that the rails would follow.

Perhaps the biggest elephant facing Kansas City and the trail system was the Border Wars of 1855-1857 and the Civil War. Guerilla fighters, like those led by Quantrill and other bushwhackers, disrupted the transportation of goods and people moving through the Kansas City region. Still, the city and its people demonstrated remarkable resiliency and survived everything the elephant threw at it.

By 1870, Kansas City had grown from a struggling trailhead town to an economic powerhouse that had experienced enormous growth. Five banks were established in Kansas City following the war: First National (1865), Kansas City Savings Association (1865), J. Q. Watkins and Company (1865), Mastin Bank (1866), and German Savings Association (1868). ${ }^{377}$ The railroad brought enormous prosperity to the city, especially after the transcontinental railroad was completed in 1869 . Texas cattle had been driven north to Missouri since the 1840s. By 1870, thanks to the newly-opened Chisholm Trail, Kansas City was doing three million dollars a year in the cattle industry, which fed the rapidly growing population of the nation. When Kansas City received an expansion

${ }^{377}$ Brown, 229. 
baseball team in 1969, they named it after the American Royal Livestock Parade and Pageant. The Kansas City Royals still sell hotdogs.

In one of the saddest diary entries, Harriet Loughary came upon the grave of a man who was said to have been killed by Native Americans. But he was not forgotten. "His faithful dog which had not been captured was watching the grave and could not be induced to leave with food or coaxing. ${ }^{378}$ The notion of "if it bleeds, it leads" did occur in the newspapers, but the death of individuals left an indelible ink. Indeed, because of marked graves, newspapers, letters, and diaries we know more about the victims of the trail than the majority of anonymous travelers that passed them by. H. L. Mencken reportedly once said that to "see the elephant" belongs to "the great movement toward the West." ${ }^{379}$ The elephant that the West presented had been explored, established, endured and embraced.

By the end of the trail period, the elephant was seized.

\footnotetext{
${ }^{378}$ Harriet Loughary, June 11, 1864.
}

${ }^{379}$ Rea, 5. 


\section{WORKS CITED}

\section{Primary Sources}

Adams, Cecelia. Personal Journal. 1852

Baker Rio Jean. Personal Journal. 1851.

Barney, Lebeus. 1859. In Letters of the Pike's Peak Gold Rush or Early Day Letters From Auraria. San Jose, CA: The Talisman Press, 1959.

Barrow, John E. Commander of Indian Affairs Report, 1849.

Bieber, Ralph P. "Some Aspects of the Santa Fe Trail 1848-1860. Missouri Historical Review 18, no. 2 (January 1924): 162.

Bingham, John A. "Camp Sites on the Santa Fe Trail in 1848." Edited by Nicholas P. Hardeman. In Arizona and the West: A Quarterly Journal of History 6, no.4 (1964): 313-319.

Bradway, J. R. Personal Journal. 1853.

Brown, James Berry. Journal of a Journey Across the Plains in 1859. The Book Club of California: San Francisco, 1970.

Bryant, Edwin. What I Saw in California. New York: D. Appleton \& Company, 1848.

Fincelius, G. Burnett. "Life of F. G. Burnett: As dictated to his granddaughter, Verna." October, 1926.

Burton, Richard. The Look of the West, 1860: Across the Plains to California Reprinted. Lincoln: University of Nebraska Press, 1862.

Clappe, Louise A. K. S. Letters. 1851.

Clark, John. Personal Journal. 1852.

Cooke, Lucy Rutledge. Personal Journal. 1852.

Cramer, Thomas. Personal Journal, 1859.

Cristy, Thomas. Personal Journal. 1850.

Dalton, John. Personal Journal. 1852.

Davis, Sarah. Personal Journal. 1850. 
Everett, John and Sarah Everett, Letters, 1856 to 1863. In Kansas Historical Quarterly (February-November 1939).

Farnham, Thomas Jefferson. An 1839 Wagon Train Journal: Travels in the Great Western Prairies... and in the Oregon Territory. New York: Greeley and McElrath, 1843.

Frink, Margaret. Personal Journal. 1850.

Goodridge, Sophia Lois. Personal Journal. 1850.

Greeley, Horace. Overland Journey. Ann Arbor: University Microfilms, Inc., 1966. Originally published Greeley, Horace. An Overland Journey from New York to San Francisco in the Summer of 1859. New York: C. M. Saxton, Barker \& Co., 1860.

Guill, Mary Jane. Memoir. 1860.

Hewitt, R. H. Notes By the Way. Memoranda of a Journey Across the Plains from Dundee, Ill., to Olympia, W. T. Olympia: Office of the Washington Standard, 1863.

Hadley, Amelia. Personal Journal. 1851.

Howlett, John. Letter, 1850.

Ingalls, Eleazer. Personal Journal. 1850.

Larkin, James Ross. Personal Journal. 1856.

Magoffin, Susan Shelby. Down the Santa Fe Trail and into Mexico. Edited by Stella M. Drumm. Lincoln: University of Nebraska Press, 1926.

Meeker, Ezra. Personal Experiences on the Oregon Trail: The Tragedy of Leschi. 1852, Seattle: Meeker, 1912.

Moore, H. Miles. Personal Journal.1854.

Parke, Charles Ross. Personal Journal. 1850.

Parsons, Lucrena. Personal Journal. 1850.

Pritchard, William Fowler. Personal Journal. 1850.

Quantrill Papers, Kansas Historical Society. 
Reid, Bernard J. Overland to California with the Pioneer Line: The Gold Rush Diary of Bernard J. Reid. Stanford University Press: Stanford, 1983.

Reports, Commissioner of Indian Affairs, 1851, 1852.

Richardson, A. D. Letter. Published in Kansas Boston Daily Journal, 1859.

Robinson, John H. Personal Journal. 1850.

Scott, Abigail Jane. Personal Journal. 1852.

Sharkey, Letter, 1856.

Swain, William. 1849. In Holliday, J. S. The World Rushed In: The California Gold Rush Experience. New York: Simon and Schuster, 1981.

Thayer, Eli. A History of the Kansas Crusade-Its Friends and Its Foes. 1889; reprint, New York: Books for Libraries, 1971.

Thomson, Origen. Personal Journal. 1852

Thoreau, Henry David. “Chesuncook.” Atlantic Monthly (June 1858).

U.S Congress. Congressional Globe. 31st Cong., 2nd sess., H. E. Doc. No 23.

U.S. Congress. Congressional Globe. 32nd Cong., 1st sess., Sen. Ex. Doc. No. 1.

Variel, Joshua. Personal Journal.1852.

Walters, Archer. Personal Journal. 1856.

Ward, Harriet. Personal Journal. 1853.

Windeler, Adolphus. Personal Journal. 1851.

Wood, John. Personal Journal. 1850.

\section{Secondary Sources}

Ackley, Richard Thomas. "Across the Plains in 1858" Utah Historical Quarterly 9, no. 33-4, 1941, 190.

Ahmad, Diana L. Success Depends on the Animals: Emigrants, Livestock, and Wild Animals on the Overland Trails, 1840-1869. Reno: University of Nevada Press, 2016. 
Ahnert, Gerald T. "Identifying Butterfield's Overland Mail Company States of the Southern Trail, 1858-1861." Overland Journal 32, no. 4 (Winter 2014): 146-162.

Anderson, Ethan. "War Flags into Peace Flags: The Return of Captured Mexican Battle Flags During the Truman Administration." master's thesis, Kansas State University, 2010.

Anderson, Richard L. "Jackson County in Early Mormon Descriptions." Missouri Historical Review 65, no.3 (April 1971): 281.

Bandel, Eugene. Fronteir Life in the Army, 1854-1861. Philadelphia: Porcupine Press, 1932.

Barile, Mary Collins. The Santa Fe Trail in Missouri. Columbia: University of Missouri Press, 2010.

Barry, Louise. The Beginning of the West: Annals of the Kansas Gateway to the American West 1540-185. Topeka: Kansas State Historical Society, 1972.

Beers, Henry Putney. "Military Protection of the Santa Fe Trail to 1843." New Mexico Historical Review 12, no. 2 (April 1937).

Beilein, Jr., Joseph M. Bushwhackers: Guerrilla Warfare, Manhood, and the Household in Civil War Missouri. Kent: Kent State University Press, 2016.

Botkin, B. A., ed. A Treasury of American Folklore: Stories, Ballads, and Traditions of the People. New York: Crown Publishers, 1944.

Brigandi, Phil. “The Southern Emigrant Trail.” Overland Journal 28, no. 3 (Fall 2010): 112.

Britton, Wiley. The Civil War on the Border vol. 1. New Yok: G. P. Putnam's Sons, 1899.

Brown, A. Theodore and Lyle W. Dorsett. K. C.: A History of Kansas City, Missouri. Boulder: Pruett Publishing Company, 1978.

Brown, A. Theodore. Frontier Community: Kansas City to 1870. Columbia: University of Missouri Press, 1963.

Brown, Randy. "Daniel Lantz and the Wayne County Companies of 1850." Overland Journal 9, no. 3 (Fall 1991): 1-6.

Butler Hulbert, Archer. Forty-Niners, The Chronicle of the California Trail. Boston: Little, Brown \& Company, 1931. 
Condran, Gretchen. "Changing Patterns of Epidemic Disease in New York City." in Hives of Sickness: Public Health and Epidemics in New York City. Rosner, David, ed. New Brunswick: Rutgers University Press, 1995.

Dary, David. The Santa Fe Trail: Its History, Legends, and Lore. Lawrence: University Press of Kansas, 2000.

Deatherage, Charles P. Early History of Greater Kansas City. Kansas City: Interstate Publishing Company, 1927.

Devine, Shauna. Learning from the Wounded: The Civil War and the Rise of American Medical Science. Chapel Hill: The University of North Carolina Press, 2014.

Eaton, Herbert. The Overland Trail to California in 1852. New York: Capricorn Books, 1974.

Ellis, Robert Binns. "Scenes and Thoughts by the Way, Trip to Northern California, 1850." Overland Journal 16, no. 2 (Summer 1998): 16-17.

Etcheson, Nicole. Bleeding Kansas: Contested Liberty in the Civil War Era. Lawrence: University Press of Kansas, 2004.

Frank, Joseph Allan and George A. Reaves. "Seeing the Elephant:" Raw Recruits at the Battle of Shiloh. New York: Greenwood Press, 1989.

Garwood, Darrell. Crossroads of America: The Story of Kansas City. New York: W. W. Norton, 1948.

Gehling, Richard and Mary Ann Gehling. "Pike’s Peak or Bust." Overland Journal 5, no. 1 (Winter 1987): 5.

Gilmore, Donald L. Civil War on the Missouri-Kansas Border. Gretna, LA: Pelican Publishing Company, 2006.

Hafen, LeRoy R. and Ann W. Hafen, eds., Reports from Colorado: The Wildman Letters 1859-1865 with other related letters and newspaper reports, 1859. A. H Clark Company, 1961.

Hahan, Garland Jefferson. Diary, April 18, 1864-May 22, 1864.

Holliday, J. S. The World Rushed In: The California Gold Rush Experience. New York: Simon and Schuster, 1981.

Holmes, Kenneth L., ed. Covered Wagon Women: Diaries and Letters from the Western Trails 1840-1890. Vol 7. Spokane, WA: Arthur H. Clark Company, 1989. 
Holmes, Kenneth L., ed., Covered Wagon Women: Diaries and Letters from the Western Trails 1840-1890. Vol 8. Spokane, WA: Arthur H. Clark Company, 1989.

Howe, Daniel Walker. What Hath God Wrought: The Transformation of America, 18151848. Oxford: Oxford University Press, 2007.

Hunsaker, Joyce Badgley. Seeing the Elephant: The Many Voices of the Oregon Trail. Lubbock: Texas Tech University Press, 2003.

Jackson, David W. "Kansas Trails, Tall Grass, and Trials as experienced in the California Gold Rush. Letters and Diary of James and David Lee Campbell," Overland Journal 23, no. 3 (Fall 2005).

Johannsen, Robert W. To the Halls of the Montezumas: The Mexican War in American Imagination. New York: Oxford University Press, Inc., 1985.

Landon, Michael. "A Continuous Line of Stock and Wagons: A Reappraisal of 1857 Overland Travel." Overland Journal 29, no. 1 (Spring 2011).

Lass, William E. "Missouri River Steamboating: The Supplier of the Oregon-California Trail." Overland Journal 30, no. 2 (Summer 2012): 30-61.

Merrill, Irving. "The Civil War in the West: The 1864 Trail Season." Overland Trails 9, no 4 (Winter 1991): 15-27.

Mattes, Merrill J. The Great Platte Road. Lincoln: Nebraska State Historical Society, 1969.

Mattes Merrill J. "The Council Bluffs Road: Northern Branch of the Great Platte River Road." Overland Journal 3, no. 4 (Fall 1985): 30.

McCaffry, James M. The Army in Transformation, 1790-1860. Westport, CT: Greenwood Press, 2006).

Miner, H. Craig and William E. Unrau. The End of Indian Kansas: A Study of Cultural Revolution, 1854-1871. Lawrence: Regents Press of Kansas, 1978.

Mothershead, Harmon. "River Town Rivalry for the Overland Trade." Overland Journal 7, no. 2 (Summer 1989): 15.

Myres, Sandra L., ed. Ho for California!: Women's Overland Diaries from the Huntington Library. San Marino: Huntington Library, 1980.

O'Brien, William Patrick. Merchants of Independence: International Trade on the Santa Fe Trail 1827-1860. Kirksville, MO: Truman State University Press, 2014. 
Phillips, Christopher. "Jennison, Charles R." Civil War on the Western Border. Online at http://www.civilwaronthewesternborder.org/encyclopedia/jennison-charles-r.

Price, David. "What is Overgrazing?” Beef Magazine, May 1, 1999. http://www.beefmagazine.com/mag/beef_overgrazing.

Rau, Weldon Willis. Surviving the Oregon Trail 1852: As Told by Mary Ann and Willis Boatman and Augmented with Accounts by other Overland Travelers. Pullman: Washington State University Press, 2001.

Rea, J. "Seeing the Elephant.” Western Folklore 28, no. 1 (January 1969): 21-5.

Rieck, Richard L. Rieck, "A Geography of Death on the Oregon-California Trail 18401860." Overland Journal 9, no. 1 (Spring 1991): 13-20.

Rosenberg, Charles E. The Cholera Years: The United States in 1832, 1849, and 1866. Chicago: The University of Chicago Press, 1962.

Schlissel, Lillian. Women's Diaries of the Westward Journey. New York: Schocken Books, 1982.

Sellers, Charles. James K. Polk: Continentalist, 1843-1846. Princeton: Princeton University Press, 2016.

Simmons, Marc. The Old Trail to Santa Fe: Collected Essays. Albuquerque: University of New Mexico Press, 1996.

Simmons, Marc. "The Old Santa Fe Trail, Part II." Overland Journal 4, no. 3 (Summer 1986), 64.

Starr, Stephen Z. Jennison's Jayhawkers: A Civil War Cavalry Regiment and Its Commander. Baton Rouge: Louisiana State University Press, 1873.

Stewart, George. The California Trail: An Epic with Many Heroes. New York: McGrawHill, 1962.

Tamony, Peter. "To See the Elephant': It is an old California expression rooted in intrepid man's eternal quest." The Pacific Historian 12, no. 1 (Winter 1968): 23-29.

Trophy, Patrick. Three Hundred Years--Historical Highlights of Nevada and Vernon County Missouri. Boulder, CO: Donna G. Logan, 1993.

Turner, John G. Brigham Young: Pioneer Prophet. Cambridge: Belknap Press of Harvard University, 2012. 
Unruh, Jr., John D. The Plains Across: The Overland Emigrants and the TransMississippi West, 1840-1860. Urbana: University of Illinois Press, 1979.

Webb, Todd. The Gold Rush Trail and the Road to Oregon. Garden City, NY: Doubleday, 1963.

Wells, Eugene T. "The Growth of Independence, Missouri, 1827-1850." Bulletin of the Missouri Historical Society, XVI (October 1959): 42-43.

Werner, Emmy E. Pioneer Children on the Journey West. Boulder, CO: Westview Press, 1995.

White, Richard. Railroaded: The Transcontinentals and the Making of Modern America. New York: W. W. Norton \& Company, 2011.

Williams, Robert C. Horace Greeley: Champion of American Freedom. New York: New York University Press, 2006.

Wyman, Walker. "Freighting: A Big Business on the Santa Fe Trail." Kansas Historical Quarterly 1, no. 1 (November 1931): 20-27.

\section{Newspapers}

Daily Intelligencer

Daily Journal of Commerce

Daily Journal of Commerce Extra

Daily Kansas City Journal of Commerce

Daily Kansas City Western Journal of Commerce

Daily Tribune

Daily Union

Daily Western Journal of Commerce

Gazette

Kansas City Daily Journal of Commerce

Missouri Intelligencer 
Missouri Republican

New York Herald

New York Times

Sunday Morning Visitor

The Enterprise

Tribune 
Darin Tuck is from the small town of Hoyt, Kansas. He graduated from Jefferson West High School, Washburn University (BA), Kansas State University (MA), and the University of Missouri (PhD). 